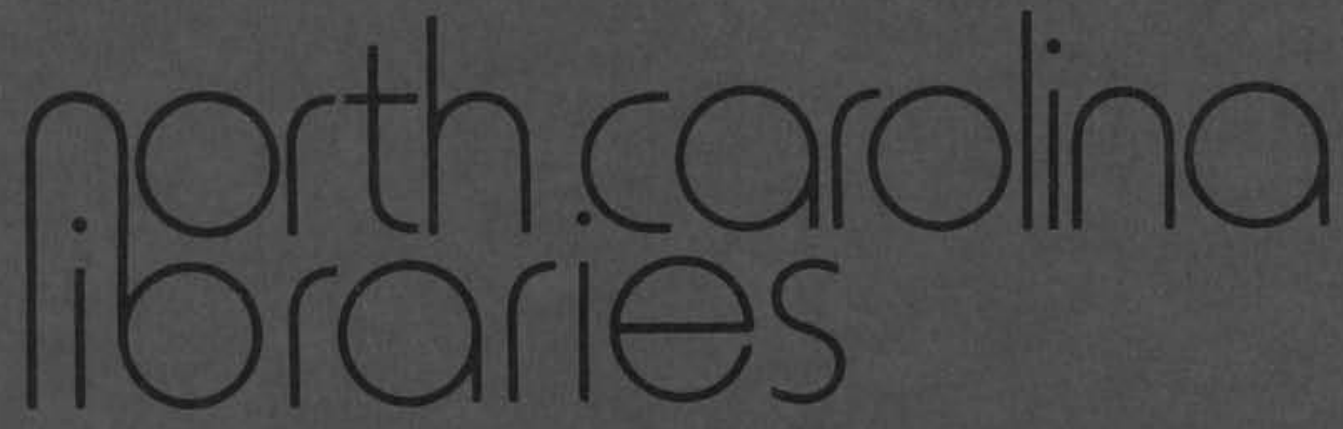

Collection development, in the strict sense of the phrase, may be a myth in many libraries.

Joline R. Ezzell, 1985

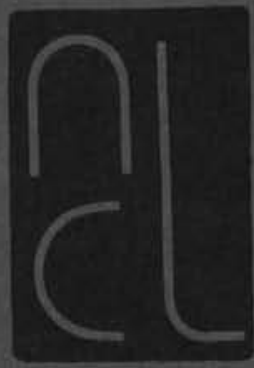




\section{NCLA EXECUTIVE BOARD}

\section{3-85}

President

LELAND M. PARK

Davidson College Library

Davirison, NC 28036

(704) 8922000 Ext 331

First Vice-President:

Presidenit-Elect

PAIILINE F. MYRICK

Moore County Schools

Box 307

Curthuse. NC 28327

(919) 947:2976

Secund Vice-President

M. JANE WII.LIAMS

Division of State Library

I09 East Jones Street

Rateigh. NC27611

(919) $733-2570$

\section{Secretany}

POBERTA S. WHLLLAMS

Transyivania County Library

105 South Broad Street.

Brevard, NC 28712

(704) $884-3151$

\section{Treasurer}

EUNICE P. BRUM

Box 40034

Palergh, NG: 27604

(919) 79344488

\section{Director}

SHIRLEY B MeLAEGHIIN

Asheville-Buncombe-Technical College

340 Victoria Road

Asheville, NC 28801

(704) $254-1921$ Ext 300

\section{Director}

JERRY A THRASHER

Cumberfand County Public

Library

Box 1720

Eavetteville. NC 28302

(919) 483. 1 580

Past President

MERTYSW. BELL.

5608 Scotland Rond

Greensboro, NO 27407

\section{AlA Representative}

EMILY BOYCE

Department of Library Setenee

East Carolina IIniversicy

Greenvilte. NC 27834

(919) $757-6621$
SEI.A Representative

REBECOA S. BAIIENTINE

Institute or Government

UNC-Chape Hill

Chapel Hill, NC 27514

(910) $966-4130$

\author{
Editor, North Carolina \\ Libraries \\ ROBERT BURGIN \\ School of Library Science \\ North Caralina Cetitral \\ University \\ Durham. NC 2770 \% \\ (919) 683-6485
}

\section{SECTION/ROUND TABLE GHAIRS}

Children's Services

KAREN M. PERRY

Archidale-Trinity Middle School

Box 232

Trinity, NC 27370

(919) $431-6714$

College and University

ROBEIT N. BLAND

Rarrsey Library

DNC.Asheville. NC 28814

(704) 258-654

Community and Junior

College Libraries

MARY AVERY

Learning Resources Center

Rowan Technical College

Box 1595

Salisbury, NC 28144

(704) $637-0760$

Documents

STUART BASEFSKY

Buke Dniversity Library

Durham, NC 27606

(919) 684.2873

Jumior Members Roma table

VIVIAN W. BEECE

New Hanover County Puhlic Library

201 Chestnur Stred

Wilmuitgton, Ne 28403

(919) 76333303

\section{N.C. Association of Schoo!}

Librarians

JUDIE DAYIE

Departmeat of Library Science: Educational Techinology

INCAreensboro

Greensboro. NC 27412

(919) 379-5100 Ext. 63
Publie Library

JUDITH $k$, SETTON

Public Library of Charlotte and Mecklenburx Counts 310 Norti Tryon Street Charlotte, NC 28202

(704) $336-2660$

\section{Reference and Aduli Service:}

LARRY BARR

Department of Libiary anc Media Studies

Appalachian State Diniversity Boone, NG 28608

(704) 262-284:

Resources and Technical Servicus BEN.JAMIN R.SPELLER, JR

School of Litirary Science

North Carolina Central Universits Durham. NC 2770 ?

(919) 683.6485

Round Table for Ethnic Minority

Concerns

MARY P WILLIAMS

I. Y. Joyner Library

Eiast Garolinu University

Gireenville, NC 27834

(919) 757-6691

Round Table on the Status of Wornen in Lilbrarianship

PATSY J. HANSEL.

Cumberfand County Pablic Library

Box 1720

Favettrille. Ne 28309

(919) 483.8600

Trustees

DOROTHY R. BURNLEY

508 Ashe Streed

Hiigh Point. NC 27260

(918) 7334838 


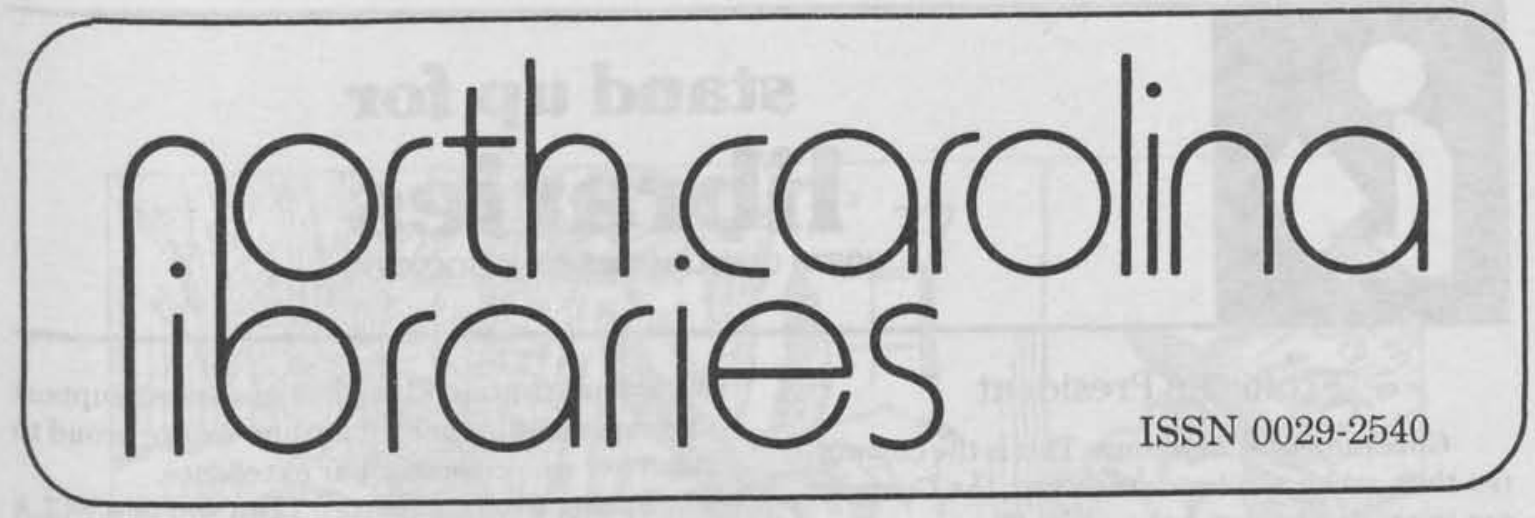

\section{TABLE OF CONTENTS}

\begin{tabular}{|c|c|c|}
\hline \multicolumn{3}{|r|}{ Intraduction Patcu Hancel and Harru Tuchmaver } \\
\hline & 5 & Building a Usable Library Collection, Harry Tuchmayer \\
\hline & 10 & Balancing the Books, Valerie W. Lovett \\
\hline & 12 & $\begin{array}{l}\text { Approval Plans as a Method of Collection Development, } \\
\text { Sallie E. Mann }\end{array}$ \\
\hline & 15 & $\begin{array}{l}\text { Faculty vs. Staff Selection: Collection Development in the } \\
\text { Academic Library, Eugene Huguelet }\end{array}$ \\
\hline & 17 & $\begin{array}{l}\text { The System of Allocations from the Book Budget at } \\
\text { UNC-G, James H. Thompson }\end{array}$ \\
\hline & 20 & Computers and Collection Development, George B. Viele \\
\hline & 23 & $\begin{array}{l}\text { Building a Serials Collection in an Academic Library, } \\
\text { Joline R. Ezzell }\end{array}$ \\
\hline & 26 & $\begin{array}{l}\text { Development of a Collection: The Music Library at East } \\
\text { Carolina University, Geraldine Laudati }\end{array}$ \\
\hline & 29 & Collecting North Caroliniana, Alice R. Cotten \\
\hline & 32 & $\begin{array}{l}\text { Developing Your Fiction Collection - Realistically } \\
\text { Speaking, Frances Bryant Bradburn }\end{array}$ \\
\hline & 35 & $\begin{array}{l}\text { Collection Development in a Municipal Public Library, } \\
\text { Robert C. Russell }\end{array}$ \\
\hline & 39 & $\begin{array}{l}\text { Collection Development in a Public Library Branch, } \\
\text { Patrice Gaffney Ebert }\end{array}$ \\
\hline & 43 & $\begin{array}{l}\text { The Hatteras Library: A Small Unit in a Regional System, } \\
\text { Anne D. Sanders }\end{array}$ \\
\hline & 45 & $\begin{array}{l}\text { Merchandising the Collection from the Small Branch } \\
\text { Perspective, Barbara Cashwell }\end{array}$ \\
\hline & 47 & $\begin{array}{l}\text { Librarians' Attitudes Toward Networking, } \\
\text { Peggy Chapman }\end{array}$ \\
\hline atures & & \\
\hline & 52 & $\begin{array}{l}\text { From the President, Leland } \\
\text { New North Carolina Books }\end{array}$ \\
\hline & 61 & NCLA Minutes \\
\hline
\end{tabular}

Cover: Joline R. Ezzell, "Building a Serials Collection in an Academic Library," North Carolina Libraries 43 (Spring 1985): 23-25. This issue features a number of observations on collection development in North Carolina libraries.

Volume 43, Number 1

Spring 1985
Advertisers: American Library Association, pp. 31, 42; Baker \& Taylor, p. 3; Children's Services Section, NCLA, p. 19; Ebsco, p. 4; Freedom to Read Foundation, p. 4; McGregor, p. 38; National Georgraphic, p. 9; Phiebig, p. 8; Ruzicka, p. 22; University Microfilms, pp. 22, 44 . 


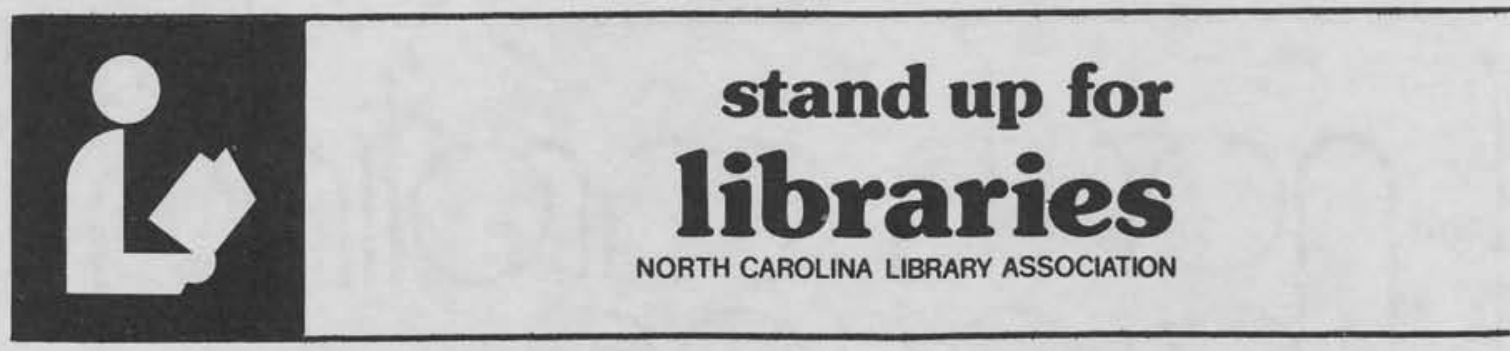

\section{From the President}

Governmental Relations. This is the committee that, when the legislature and the Congress are in session, stays on the move. There are days planned for librarians to "press a call" on their representatives in Raleigh, and the trip to Washington in April during National Library Week is all set. With the fifth largest library association in the country having highly visible membes in each of North Carolina's one hundred counties, it is a formidable force when organized. Keep in touch with your section chairmen and/or Louise Boone, who heads up the Governmental Relations Committee for NCLA. They can use your help to "Stand Up For Libraries."

MsM Interviews. Be sure to catch the publication of the Round Table on the Status of Women in Librarianship, MsManagement. It's excellent, and the interviews with librarians of note in our state are uniformly interesting and informative. Jane Williams, Elaine Von Oesen, Dale Gaddis, Mattie Russell are just a few of the notables interviewed. And it makes you even more proud to be a part of this profession in North Carolina.

Government Documents. There are thirtyfive federal depository libraries in North Carolina, from the mountains to the coast. Their resources are vast and rich, and they work together in collection development and resource sharing. A new North Carolina State Documents Plan has been written delineating the organization of the materials and how they may be accessed by everyone. Jaia Barrett (Duke), Jean Porter (NCSU), and Ridley Kessler drew up the plan. If you don't have a copy for your library, write Mr. Kessler, the regional depository librarian, at Davis Library, UNC-Chapel Hill.

New Scholarship Fund. Elsewhere in this issue you will find the exciting news of a gift to one of our sections, NCASL, of $\$ 5,000$ by NCLA president emerita Eunice Query to establish yet another scholarship fund for library school students. Miss Query has worked hard for library education for decades; in her retirement she has proved that she "practices what she preached,"
We are most grateful for her continued support and especially for her friendship. We are proud to claim her as a colleague par excellence.

Spring Workshop. April 12-13 will find NCLA hosting its annual spring workshop at Greensboro College. We are entering the home stretch of the biennium, and this is an important time for committees, the executive board, and section officers to meet and make plans for the October conference and other activities during the next several months. All meetings are open; join us.

Raleigh Conference. Pauline Myrick and her committee are working hard on the fall conference in Raleigh. Speakers for the general sessions and banquet will be announced soon, and I think you will be most pleased. Sections are firming up plans for their meetings, and exhibitors are being contacted. (Ask salesmen if their firms will be represented; contact Bill Kirwan at Western Carolina for information.) It is a great undertaking to put a conference together, and NCLA has a reputation for outstanding ones. Plan to be there: October 2-4.

Membership. Renewals for memberships have been mailed by treasurer Eunice Drum in the last several months. If you received one, be sure to renew right away. You don't want to miss any issues of North Carolina Libraries, Tar Heel Libraries, ballots for officers (which will be mailed in late Spring), or information about the conference. Besides, NCLA needs you!

Tag News. A librarian's car made the news recently! Martha H. Davis, library director of the Rockingham County Public Library, has recently installed a new CLSI LIBS 100 circulation system in her libraries. Mrs. Davis is so pleased with the system and so interested in spreading the word in her county about the libraries' new venture in automation that she has "LIBS-100" as her car's license plate number. Check the Winter 1985 issue of Newsletter of Library Automation (p. 15) for a super picture.

Next Executive Board Meeting: Greensboro, April 12-13, 1985.

Leland M. Park, President 


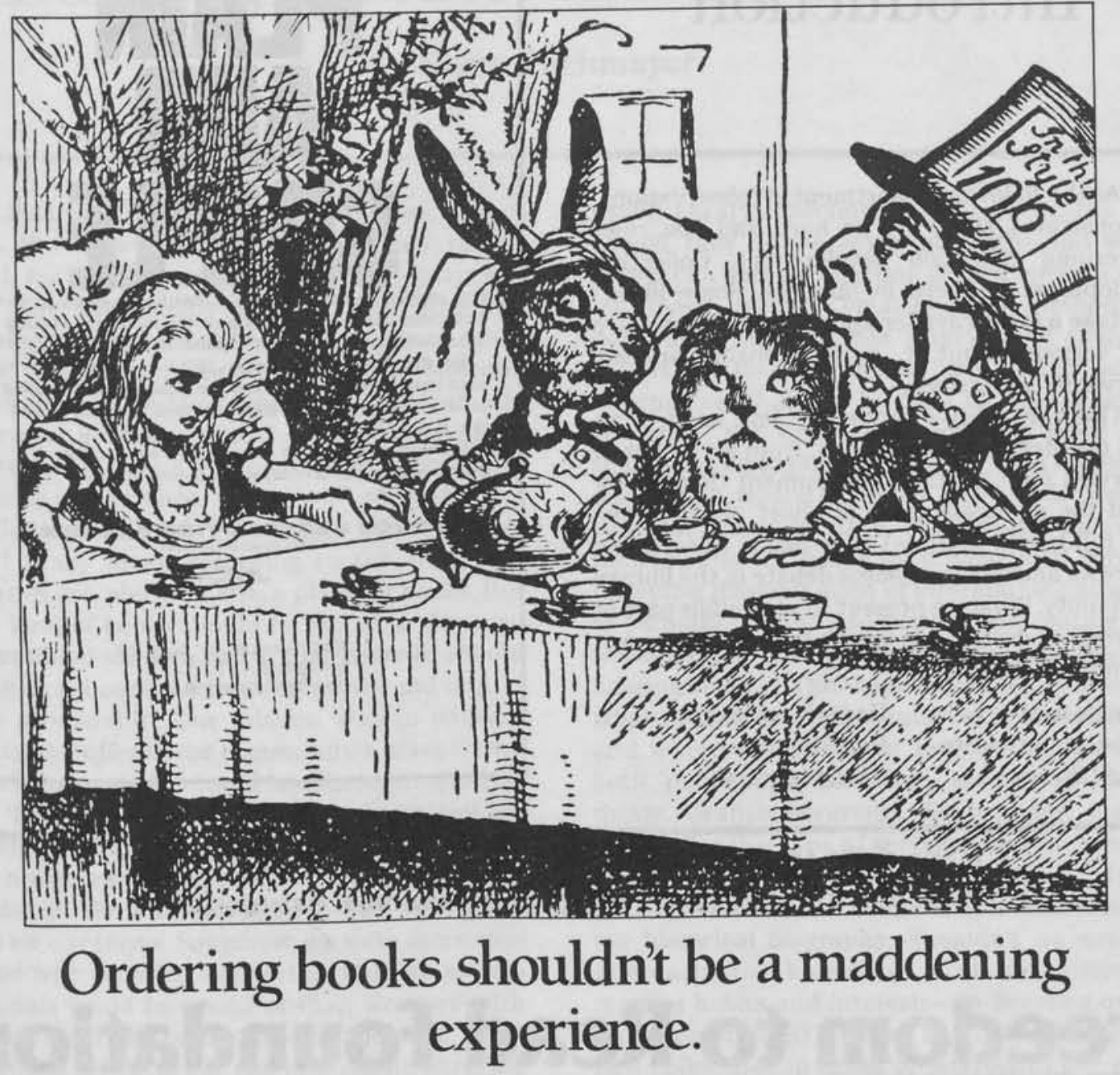

Dealing with an inflexible book supplier is no tea party.

That's why so many librarians prefer to deal with Baker \& Taylor. For over 150 years we ve been listening carefully and responding with economical and customized methods to help librarians get the most from their budget.

We've developed time-saving, cost-effective programs like our Continuation Service, Book Leasing System and Approval Program. And our electronic ordering services like BaTaPHONE BaTaSYSTEMS," and LIBRIS II ${ }^{\mathrm{TN}}$ are state of the art. All have been developed with the help of professional librarians who understand the needs of today's libraries.

So whenever you have any questions about how to improve your book ordering services, ask Baker \& Taylor:

You can expect some very straight answers. And that's no fairy tale.

Call or write us now BAPERIENCE YOU CAN DEPEND ON

Eastem Division. 50-Kiby Avenue Somerville. N] 08870 (201) 722-8000 Midwestem Division, 501 S. Gladiolus Street. Momence. IL. 60954 (815) +72-24t Eastern Division. 50 Kurby Avenue. Somerville. N 08870 (404) 335-5000 Western Division, 380 Edison Way. Reno, NV 89564 (702) $786-6700$ 


\section{Introduction}

As the following assortment of "observations" demonstrates, there are no hard and fast rules concerning collection development. Collection development happens in libraries. Some librarians take a fairly cavalier approach to it, some are very serious about it, most probably operate somewhere in between.

This variability in approach lent itself to an issue devoted to "observations" from a number of librarians on collection development themes. We asked for an assortment of short observations (not full-length articles) that might raise a few eyebrows and generate some debate in the library community. What we present to you fulfills part of our original design; it is left up to you, the reader, to complete the project.

$\begin{array}{ll}\text { Patsy Hansel } & \text { Harry Tuchmayer } \\ \text { Cumberland County } & \text { New Hanover } \\ \text { Public Library } & \text { Public Library }\end{array}$

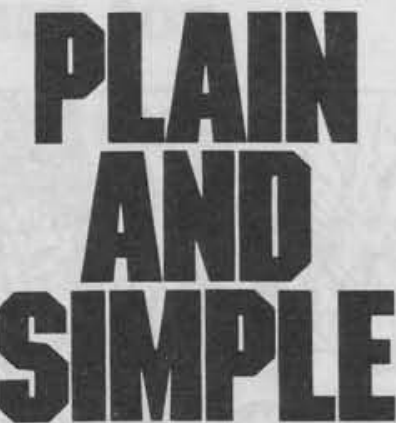

Our physical size and financial strength-necessary to make and honor commitments-indicate the successful working relationships we have with thousands of libraries worldwide.

But the plain truth is, simply, that it is our sensitivity to your unique requirements, and our flexibility in providing an exhaustive and relentless effort for total customer service that is our real strength.

We want to work with you-to help you provide exceptional patron service, which is your strength

We can help. Write todayEBSCO SUBSCRIPTION SERVICES

$$
=\Longleftrightarrow
$$

8000 Forbes Place, Suite 204

Springtield, VA 22151

(703) $321.7494 / 321.9630$

\section{If the right to express your ideas is important to you... then you can help fight suppression of free expression.}

\section{Freedom}

The battle is an important one. Today reports of attempts to censor books and information are at record highs. Any book, magazine, photograph or other material can be the target of would-be censors from the left. right or center.

Your membership in the Freedom to Read Foundation can make a difference in protecting the free flow of information and ideas - the basic principles of the First Amendment.

The Foundation is a 14-year-old organization of librarians, lawyers. educators, booksellers, authors, publishers and other concerned citizens who have joined together to safeguard the tradition of free expression in America. The Foundation provides legal and financial support to those at the frontline of censorship challenges.

\section{to}

Your membership in the Freedom to Read Foundation will:

- help support librarians across the nation who are beleaguered by raids on our libraries

- expand the freedom to read by offering legal and financial help in cases involving authors, publishers and booksellers

- entitle you to the Freedom to Read Foundation News, a quarterly newsletter on censorship trends. current court cases, legislative developments, and reports of successes in bouts with censors.

Books and ideas aren't dangerous but information restraints on a free people are. Protect the future of the First Amendment. Join the Freedom to Read Foundation.

\section{Foundation}

Yes, I want to become active in the Freedom to Read Foundation

My membership check for \$ is enclosed. This tax-deductible contribution entitles me to vote for Foundation trustees and to receive the quarterly Freedom to Read Foundation News.

$\square \$ 10$ student $\square \$ 100$ sponsor $\square \$ 25$ regular $\quad \square \$ 500$ patron $\square \$ 50$ contributing $\square \$ 1000$ benefactor

Name

Address

City

State Zip

Please make checks payable to Freedom to Read Foundation and mail to Freedom to Read Foundation, 50 E. Huron St., Chicago, IL 60611. 


\title{
Building a Usable Library Collection
}

\author{
Harry Tuchmayer
}

Librarians have lost touch with their collections. When new advances in management theory called for participatory management practices that took the employees' needs into account, librarians were quick to become "personnel managers." When automation continued to blossom, we became "information scientists." And it should come as no surprise to see that as those in education return to basics, we too find ourselves thinking along similar lines.

But does a return to basics in the library world really mean returning to the three Rs? Libraries are, above all else, a place for books. But what kind of books should be there? In the past, conventional wisdom had it that libraries should be the storehouses of great literature and impeccable scholarship. Our mission was to educate society and offer to the community a place where those who wanted to could familiarize themselves with "high culture," as a means towards self-improvement. Paperbacks were unheard of and pulp novels rarely raised their "trashy" heads in the stacks. We wanted readers-but we wanted them on our terms. Somehow, we were more concerned with building a collection that we as professionals could be proud of than we were with building one that could and would be used.

Today all libraries, not just public libraries, are at the crossroads. We are faced with a demanding clientele and a publishing industry that is producing more and retaining less. We need to be responsive to these demands by supplying our customers with the books and materials they want and need when they want and need them.

\section{Cornerstones to Collection Building: Identify- ing Your Users and Their Needs}

Each library serves a distinct community of users. Identifying who these users are and what their needs may be is not an easy task. However, it is the necessary first step in attempting to build a

\footnotetext{
Harry Tuchmayer is Head of the Technical Services Department of the New Hanover County Public Library in Wilming. ton.
}

usable library collection. How do we identify user needs? How do we assess strengths and weaknesses of a library collection geared towards serving these needs? Certainly such methods as community surveys, user surveys, and analyzing circulation records will all have certain bits of information that can be used to build a library collection, but we need to do much more than that. We need to pinpoint areas both in nonfiction and fiction where customer demand is present. Business libraries have successfully identified their customers' needs by utilizing SDI services (selective dissemination of information) as a way of earmarking new information and routing it to those people who would be most interested in hearing about it. They have succeeded by knowing what projects certain employees are working on and where their fields of interest lie. Libraries, both public and academic, should do similar things. Branch librarians, for instance, instinctively offer this type of service when they inform regular customers of the publication of Harold Robbins's latest novel or the arrival of an interesting historical biography. Shouldn't we use this approach-our knowledge of all our customers' reading habits and interests-in deciding on the purchase of titles? We need to build viable nonfiction collections in areas of interest to our clientele. This means buying multiple copies of good how-to books for the public library. It means buying multiple copies of the standard scholarly source for the history student at the undergraduate institution. The fact remains that somewhere in the backs of our minds, we have always been able to identify the needs of our customers. The problem is that we have been "unwilling" or "unable" to supply them. Unfortunately, many of us believe, or were taught to believe, that the quantity of titles is more important than the appropriateness of the volumes we have.

Traditionally, academic libraries, especially the four-year institutions, have shied away from multiple copies of a particular title. The incentive has always been to buy as many distinct titles as possible. But does this really serve the clientele? Does it do the undergraduate any good to find an 
esoteric title on the American Revolution when any one of three standard sources would have been perfectly acceptable for the report he needed to write? Keeping up with the scholarship in the field, communication with instructors, figuring out what courses are offered, and what requirements are being asked of the students, all play an important part in helping the librarian decide which materials to purchase. Similarly, in the public library, numerous areas can be identified as being "bottomless pits"-areas where an unending number of titles could be provided to a multitude of customers. The question becomes, "Should we provide multiple copies of good sources or look for one more copy of one more title to fill this need?" Librarians ought to spend the time necessary to select standard titles in these areas and then purchase multiple copies of them. This will ultimately provide the customer with a better selection of materials and a greater likelihood of obtaining them. Quality service results from quality collections, and quality collections are built not by the number of titles held but by the usefulness of the titles in the collection.

Building a collection that meets customers' demands does not mean buying "trash." Rather, we should look at collection building in much the same way as any major department store looks at merchandising. Quality stores exist and thrive when their stock meets the varying needs of the customer. In the same fashion, the library has an obligation to provide its customers with all of their literary entertainment and information needs. The local department store has no problem carrying Pierre Cardin and Liz Claiborne clothing on racks across the aisle from Levis and "designerless" brand labels. Why should we in the library world see a problem with multiple copies of In Search of Excellence and Come Love a Stranger coexisting on the new book shelf? Building a usable collection is synonymous with developing a quality collection. It requires a commitment on the part of the library to actively purchase and collect from the entire range of published materials.

\section{Process of Collection Building: Selection and Acquisition of Materials}

Identifying what your customers want is only the first (and perhaps easiest) step in building a usable collection. Selecting the appropriate material and guaranteeing its prompt delivery and speedy access by the customer complete the process.
What we select has a direct bearing on how well our library is used. Unfortunately, in many libraries the selection process is far removed from the demands of the customers. In many academic libraries, faculty selection constitutes the bulk of the monographic selections; in many public libraries, selectors are enticed by salesmen and seduced by reviews. Nowhere in this process are the concerns of the primary users of material placed at the forefront of the selection process.

Reviews in such publications as Booklist, Library Journal, and most scholarly journals offer competent and sound advice concerning the "quality" of the items in question, yet they provide us with this information months after the date of release. Add to this the lag time involved in the ordering and processing procedures of most libraries, and we are confronted with delays in receiving "new" materials that reach upwards of six months. Does it benefit any of our customers when they wait months for the next Robert Ludlum bestseller or an academic work by the leading scholar in the field?

\section{Building a collection that meets customers' demands does not mean buying "trash."}

Of course, libraries have developed "mechanisms" to deal with this, so we buy bestselling authors without the benefit of reviews and establish approval plans and blanket orders for books by renowned publishers in specified disciplines. Why the dual standard? Why subject the rest of our collections to this standard of "quality" when we turn our heads in the case of some of our most heavily used, or most extensively purchased, materials? Part of the answer is knowledge-we intuitively know what our customers are looking for. And part of the answer is time and the recognition that speed matters. It matters because our customers demand it and the publishing industry requires it.

Short publishing runs and the ever-increasing demands for timely information on the part of all library customers have changed the ground rules for the selection of materials. We must order materials based upon prepublication announcements and reviews; speed up the selection process by creating selection "teams" or committees that are responsible for the selection of materials for 
the entire system; streamline the ordering process by centralizing the selection process; and reduce the time it takes to process materials by recognizing that Technical Services is, first and foremost, a public service.

How do we accomplish this? First, let us demand that the periodicals that supply us with reviews shift their emphasis to prepublication. Vendors have already recognized this need by publishing monthly magazines that "mirror" $P W$. . Why not insist that Choice, $L J$, Booklist, and others offer prepublication reviews? Why not request that scholarly journals run their own reviews from galleys? Use the prepublication sources that are available and use them heavily. Advertising budgets, author tours, and publication runs inform us of the potential demand any title will see. We should stay attuned to these demands, both real and potential, and devise alternate sources of information on books. Keeping in touch with what the local bookstores sell is a good starting point. Local talk shows, popular magazines and upcoming community events also reflect your clientele's interests.

Let us revamp our selection processes to best meet these challenges. First, the public library should create selection teams that meet regularly and decide the fiction and nonfiction book selection for the entire system. The team should be of a manageable size (three to four maximum), meet once every three weeks, and represent all areas of library service, openly soliciting and encouraging suggestions for purchase from all interested staff. Allocate a specific dollar amount to be spent solely on mass market paperbacks. Make this the primary responsibility for each branch librarian. This will allow them to immediately satisfy demand for current literature-a demand that already exceeds 20 per cent of most public libraries' total circulation. ${ }^{2}$ Otherwise, do away with hard and fast budget allocations for each branch and instead purchase to meet demand. Reasonable guidelines should be established, depending on the library's budget and service requirements. Cut down on time-consuming bibliographic checking by staying ahead on orders, centralizing the process of selection, and utilizing different channels for ordering items. Make arrangements with local bookstores to buy paperbacks at a maximum discount. Use your standard high discount vendor for all current purchases and establish different procedures for those items earmarked as collection redevelopment.

Priority must be given to processing new material quickly. Stop relying on technical services departments as backups to traditional public services and instead realize that fast turnaround time is a public service. Providing new material to your customers before, or at least at the same time as, the local bookstores do informs your clientele that the library does service their needs. (It also reduces the need to buy additional copies of many titles by getting a head start on the reserve list.)

Making the selection of material a priority operation of library services is the ultimate goal of the process of collection building: the emphasis should be placed upon staying current, providing

\section{We must reduce the time it takes to process materials by recognizing that Technical Serv- ices is, first and foremost, a public service.}

your customers with the information that they want, when they want it.

\section{Collection Building as a Total Library Policy: Guaranteeing That the Books Get Used}

Buying current material that is in high demand is only part of the process of building a usable library collection. Oftentimes, needs change and holes develop in our collections. Or, as is more often the case in heavily used sections of the library, our collections either cannot support the demands of the customer or have lost a good percentage of the material through attrition. For whatever reason, it is important that the entire collection, both nonfiction and fiction, be examined and evaluated on a regular basis. The objective is to identify strengths and weaknesses in the collection and to make recommendations for weeding and purchasing of materials in order to update the holdings.

Each member of the professional staff should be assigned specific areas of the collection. A major part of each person's responsibility would be to personally examine the holdings and look at the changing activity of the items in that section. Then a detailed report could be prepared to identify which specific areas need to be weeded, where the collection appears to be strong or weak, what areas contain sufficient materials to meet apparent demand and what areas need further strengthening. These reports should be organized around specific LC or Dewey class numbers and a priority ranking of areas deemed most in need of material should be provided. The collection development 
librarian could then review these reports against circulation statistics broken down by specific class number. Then some final recommendations concerning where the library should begin its collection redevelopment process can be made.

The by-product of this detailed attention to the collection is three-fold. First, it aids in the purchasing of new materials by reaffirming areas of high demand. It also indicates to those responsible for certain sections why the library does not need to purchase just another good title in an area of low demand. New purchases in these areas can therefore be tailored to meet various needs and a realistic attempt at developing a truly "balanced" collection-one where the library has the appropriate amount of good material available in all areas of the collection-can be made.

Second, it reminds us that library collections are not static. Unlike our own personal collections of books, library material has a high level of attri-

\section{Why not insist that Choice, LJ, Booklist, and others offer pre- publication reviews?}

tion. One cannot reasonably expect all the materials we have purchased over the years to either still be available (items do get lost, stolen, or deteriorate beyond use), or be worth having in the current collection. ${ }^{3}$

Finally, it brings the entire professional staff back in touch with the primary purpose of the library. Librarians not only need to be aware of what our customers want-we need to be constantly aware of what we have to offer them. This type of attention to the collection is not designed to produce better librarians but better libraries. A nice by-product, of course, is that it does produce better librarians.

Our goal, as professionals, is to build a usable library collection that meets the needs of our customers. This goal is our overriding objective, and we must accomplish it with the same zest and enthusiasm we have put into automation and managerial concerns. This is not to say that positive trends in personnel management and automation have not been beneficial to the library world. They have, but the emphasis needs to be shifted to make them beneficial to the process of collection building. Let us restore the importance of this activity to the profession. Library schools must stress collection development as the corner- stone of the profession; library administrators must emphasize this activity among their staffs; and reference and technical services librarians must devote as much time and energy to this as we have to automation. Libraries can meet demand and build quality collections at the same time. It doesn't necessarily take money; but it does take time and commitment. Only when we approach collection development with this commitment to excellence will we begin to develop a truly usable collection.

\section{References}

1. Ingram's Advance Magazine offers the best example of this trend. Other vendors, such as Brodart's T.O.P.S. (Titles of Prime Selection), Baker \& Taylor's Forecast, and Waldenbooks' Bestseller, carry similar publications.

2. New Hanover County Public Library circulation statisties for the year 1984 show that over 22 per cent of the main library circulation figures are a result of mass market paperbacks. Figures for the branches exceed 50 per cent.

3 . Active weeding is recommended for all libraries, academic and public, with the exception of those libraries truly designed to support major research operations, primarily Ph.D.-granting institutions.

\section{FOREIGN BOOKS and PERIODICALS}

\section{CURRENT OR OUT-OF-PRINT}

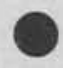 \\ SPECIALTIES: \\ Search Service \\ Irregular Serials \\ International Congresses \\ Building Special Collections
}

\section{ALBERT J. PHIEBIG INC. Box 352, White Plains, N..Y. 10602}




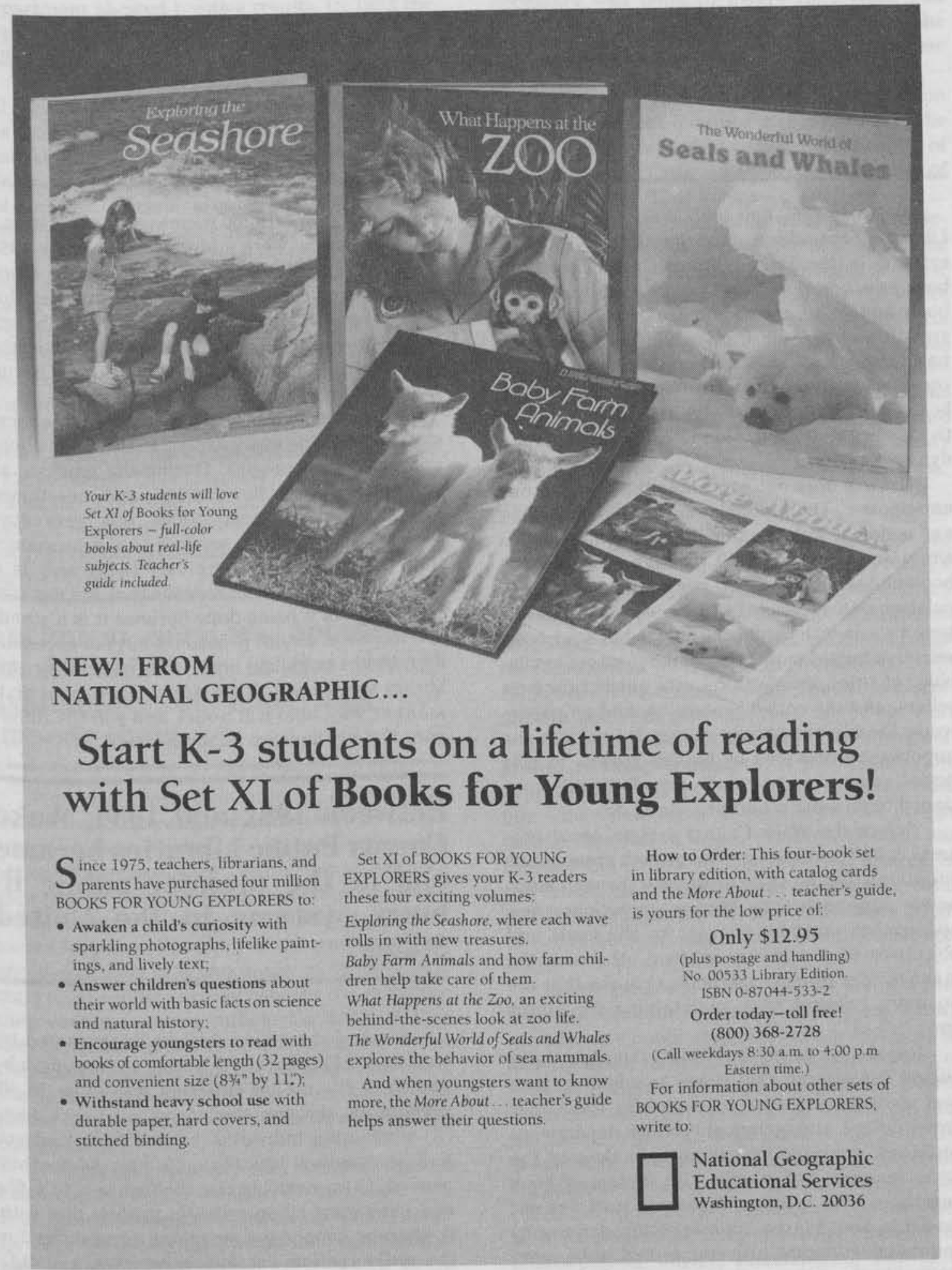




\title{
Balancing the Books
}

\author{
Valerie W. Lovett
}

Between 1982 and 1985, Wake County Public Libraries became one of the premier public library systems in the United States. It redirected its book selection policy and used a rapidly growing book budget to create unparalleled circulation growth among American public libraries in the past three-and-a-half years. Its creative approaches to the challenges offered by growth can be examined by others wishing to create a pro-active library system whether or not a rapid growth dynamic exists.

Growth does not guarantee the progress one anticipates. The initial years of book budget expansion at Wake County are an example of this situation. From FY 1979 through FY 1981, the book budget increased 60 per cent, but book circulation only increased 13.5 per cent. During this time a six-month cataloging backlog existed, book selection lagged months behind bookstore availability of titles, long waiting lists queued for best sellers, and the entire process choked on paperwork. Clearly, the library system did not use the opportunity provided by budget growth to give better service to the community. It merely continued to do what it had previously done.

Before the Wake County system could progress, it had to recognize that growth creates new situations that must be dealt with through alternative approaches to library operations. New approaches must be relevant to the goals and objectives of the library system; otherwise the management process will make changes that are no more relevant than maintaining the status quo.

Rapid increases in Wake County's book budget highlighted two areas in which change had to occur in order to capitalize upon that growth. First, the technical services department could not continue its current practices in the same manner and handle the increased book purchases. The option of increased staff was not available. Second, the book selection philosophy and its concomitant procedures had to be reexamined because the available new funds were not

Valerie W. Lovett is Assistant Director of the Wake County Public Libraries in Raleigh. producing proportional increases in circulation.

Both areas were addressed during FY 1982.

The new library director, Tom Moore, set a performance objective for technical services that books were to leave that department fully processed within five days of receipt. This objective recognized the public service need of having materials promptly available to the public.

This objective forced the technical services staff to examine every aspect of the acquisitions and cataloging process. During the analysis, all procedures were flowcharted and questioned from this perspective: "Does this procedure directly benefit public service? Is it a procedure that has lost its meaning over the years? Is it being done for internal reasons that are not cost beneficial? Is it being done because it is a standard technical service procedure but not necessarily relevant to public libraries in general or this library specifically? If we stop doing this, or do it another way, who will notice and will the difference directly improve public service?"

\section{Between 1982 and 1985, Wake County Public Libraries became one of the premier public li- brary systems in the United States.}

Some of the major changes implemented by staff were: (1) using the available accounting subsystem of the on-line ordering system to do all accounting, thereby eliminating all paper files; (2) eliminating individual branch book budgets and instructing branches to buy what they needed; (3) converting the shelflist to a title file and combining all on-order/in-process files with it, thereby simplifying searching procedures for the order section, cataloging, reserves, and ILL; and (4) removing the accessioning process from the book flow by ceasing to add accession numbers to holdings information. 
Changes made in Wake's technical services department showed positive results. In 1982 the department processed 53,474 books. In 1985 it will process 104,000 books with fewer staff.

These are not traditional solutions to technical services production problems; however, given the stated objective, technical services found innovative ways to reach the objective without diluting the quality of its product. Indeed, technical services operations must contribute to the timely availability of materials, not impede them.

The same statement can be made about the book selection and acquisitions process of a library system. Unlike its approach to the operations problems of the technical services department, library administration initially addressed the existing problems in book selection and acquisitions from a philosophical basis. From the analysis of book budget growth vs. circulation growth, from the data collected during a systemwide inventory, from the reserve lists for popular materials, and from the comments by library users, it was evident that the library system was not purchasing materials in a way that satisfied patron demand.

\section{Technical services operations must contribute to the timely availability of materials, not impede them.}

With this information in hand, the administrative staff had extensive discussions about the direction book selection should take. An examination of the Baltimore County Public Library's approach to book selection favorably impressed the administrative staff. Thus, the administration moved from the philosophy of the traditional balanced collection to a philosophy of demand buying, i.e., providing current patrons the materials they want and need in sufficient quantity so that they are reasonably certain of finding that material when they come into the libraries. Therefore, the collection is balanced based on user needs rather than on arbitrary standards of collection composition.

Putting that emphasis into practice required restructuring the entire selection and order process. Selection was centralized into a book selection committee, meeting weekly and composed of administrative staff and branch heads. Batch ordering for all branches was reintroduced, thereby improving upon the efficiencies achieved in the order section the previous year. Pre-publication purchasing from ads was accelerated. Everything necessary was done to insure that Wake had enough copies of a book in its branches by the time that a bookstore was displaying the same book.

A decision to purchase a title is based upon the question of the quantity that is needed in the system. It is as important to purchase 4 copies of Allen Ginsberg's Collected Poems as 297 copies of Joe McGinniss's Fatal Vision.

The selection process has been an evolutionary one. One cannot implement demand buying without making mistakes. Procedures have changed over the past three years as the entire staff has become more experienced in the process, and we expect change to continue. What has not altered is the philosopy behind the selectionthat public libraries exist to provide the public with the materials that they want to read and that public use is the yardstick by which a library system measures and evaluates its performance.

\section{Examining Public Response}

Public response to the redirection of the selection philosophy can be examined. From FY 1982 to FY 1985 the book budget of the library system grew 112 per cent (from $\$ 406,980$ to $\$ 861,700$ ). Projected circulation growth through the same period is 113 per cent (from $1,080,993$ to $2,300,000)$. This is a measurably better performance in materials selection than the 60 per cent book budget growth vs. 13.5 per cent circulation growth in the preceding three fiscal years. The proportionality of the two growth rates is a valid indication that Wake County is on the proper course. However, it appears that the system has reached the crossover point for these figures. In the future, circulation growth should be greater than book budget growth as a cumulative result of better book selection and collection management.

Rapid growth in a book budget is not a prerequisite condition to demand buying. Any library can examine public response to its purchasing by looking at its circulation figures in a variety of ways-circulations per capita, population growth vs, circulations growth, potential circulation projection vs. real circulation, and so forth. If the examination does not show an active and increasing response to book purchases in the use of the collection, that library should not be satisfied with its performance. It should re-examine its philosophy of buying, remembering that it is accountable ultimately to its paying customers, the taxpayers, for effective use of their tax dollars. 


\title{
Approval Plans as a Method of Collection Development
}

\author{
Sallie E. Mann
}

Over the past four decades, the subject of book selection has occupied a prominent place in the professional literature of librarianship. Few topics have been so consistently under professional scrutiny as the process by which library materials are selected and acquired.

"Herman Fussler, when he was director of libraries at the University of Chicago, voiced this opinion: 'I venture to say that (a) the most important, and (b) one of the most difficult activities in ... a [research] library is the selection of books and other materials.' Harvard librarian Kayes [sic] Metcalf expressed a similar view in 1950: The greatest single problem in acquisition for a research library ... is the selection of new books ...' Speaking before an international audience in 1967, J. Periam Danton stated his conviction that book selection is the most fundamental, the most challenging and the most indispensable function of a library.' He added that 'aside from the fundamental consideration of budgetary support there are no matters of greater importance for the library-and its patrons.' Another writer, James Skipper, then assistant director of libraries at Princeton, expressed precisely the same opinion in saying 'I can think of no higher responsibility of a library than to build the best possible collections, with the resources available."'1

"With the feeling of professional pride and responsibility for book selection running so deep in the ethos of librarianship, it is understandable that academic librarians have viewed with concern selection techniques which tend to shift the responsibility for book selection from the library to other individuals or agencies. Especially have librarians been skeptical of commercial agencies which offer to select or pre-screen books for individual libraries. Traditionally ... academic library collections have been built jointly by librarians and faculty members ... Historically, in many colleges and universities primary responsibility for

Sallie E. Mann is Education Librarian for the Curriculum Materials Center at East Carolina University in Greenville. The full paper was presented at the NCLA Resources and Technical Services Section mini-conference in Whispering Pines in September 1984. book selection has been vested in the academic departments, while in others this function was carried out almost entirely by librarians. Between these two extremes, a broad spectrum of selection practices has developed, delineated by various combinations of shared responsibility. Regardless of where the ultimate decision-making authority for book selection lay, however, the actual selection process almost always involved a separate decision, either by faculty members or librarians, for each title added to the library. Thus academic library collections were the cumulative result of hundreds upon hundreds of individual decisions." ${ }^{2}$

A pattern of selection has been slowly evolving in which an increasing amount of scholarly library materials are being acquired more or less automatically through a variety of acquisition programs known as blanket order plans, gathering plans, and approval plans. Though these various programs differ somewhat in purpose and scope, they all are designed to supply mass quantities of books without the library staff initiating individual orders. These purchasing plans are essentially an agreement between a library and an agent or publisher in which the library agrees to purchase all of a certain set of publications or to select from books sent and return any unwanted books.

Almost all research libraries active in acquisitions have found it necessary to set up approval plans for books published in the United States, Latin America, Western Europe, and other countries or language areas of particular interest to their curriculum. These plans, which are defined in nature and scope by the needs of each particular institution, have been necessitated by the everincreasing numbers of contemporary publications that have made it almost impossible for any library to order these multitudes of titles on an individual basis. Since unwanted titles can be returned, these comprehensive plans do not obviate the principles of selection. The library has an opportunity to review what titles are to come and what others are required before the volumes actually arrive. 


\section{Divided Opinion}

The published literature shows divided opinion on the question of whether these plans actually improve the overall acquisition programs of the libraries they serve. Proponents of approval plans point out that they are practical, provide for better evaluation of the material in question, deliver books soon after publication, speed up the acquisition process, reduce clerical costs by the convenience of single billing and elimination of single orders, minimize bibliographic checking, and assure broader coverage of current monographs. They also argue that, by providing automatic coverage of certain categories of new publications, approval plans free librarians and teaching faculty to concentrate their selection efforts on the more obscure items and on retrospective collection building.

On the other hand, these plans are not without critics. Opponents maintain that the mass purchasing plans tend to produce canned libraries-all having virtually the same collectionsand that most plans fail to supply multiple copies, so additional ordering is required. Critics claim that it is difficult to determine whether particular titles will be received and that evaluation is more

\section{Few topics have been so con- sistently under professional scrutiny as the process by which library materials are selected and acquired.}

difficult and time-consuming because books are frequently received before scholarly reviews are available. Some maintain that by participating in these programs, academic librarians may actually be slowly abdicating their responsibility to build strong collections geared to the unique needs of a given academic community. This would be particularly true in cases where the library staff fails to evaluate carefully incoming books or neglects to follow up the approval plan with individual orders for books missed by the dealer's selection network.

Blanket orders are, in effect, a broad based standing order. Examples of blanket orders would be agreements to purchase everything published by a university press or all new books published in a designated subject area from a selected publisher. Normally, a characteristic of a blanket order is that the library must pay for and keep whatever material is sent.
Approval order plans, on the other hand, are books sent by arrangement, or if you will, "on approval." These plans are set up so that unwanted volumes may be returned. They are usually initiated as an attempt to speed up and make more efficient the acquisition of new publications, usually on a rather broad scale. A typical example would be asking a jobber to supply a library with all publications in English, selecting specific subject areas to be covered. Within the framework of broad subject categories, exclusions would be determined; for example, no fiction, no medicine, or no lower-level textbooks. The major difference between blanket and approval plans is the option to select and return books not wanted to the jobber.

To cope with acquisitions problems, academic libraries have implemented blanket orders and approval plans. Traditionally, book selection in academic libraries has operated under the strong influence of the teaching faculty. Pressures to acquire even greater quantities of materials in a time when there is an increasing number of titles from which to select have produced a trend away from faculty selection and title-by-title ordering of books. Consequently, a larger role in selection of materials is being given to librarians as a result of heavier reliance upon blanket orders and approval plans for book acquisition. Some libraries have developed a corps of bibliographers, each with one or more subject areas for which they are responsible. They initiate book orders and are responsible for the depth and maintenance of the collection in their respective areas.

Approval plans are becoming more the rule than exception for selection in large academic libraries. Summarizing a report on approval plans of forty-four academic libraries, Norman Dudley reiterated the need for careful review of approval materials received. He indicated "that if materials are not reviewed with thought, discrimination, and some measure of professional expertise, if close contact fails to be maintained with bibliographic sources, and if new orders are not generated, then it is likely that the library will lose its flexibility and fail to meet its responsibility to respond to changes in the academic environment." ${ }^{3}$

\section{Raney's Study}

Leon Raney conducted a study of the effects of a domestic approval plan on book selection in a given academic library. His study simulates the application of a commercial approval program to a medium-sized academic library for the purpose 
of determining how closely approval plan selections relate to the existing pattern of book selection in that library. The investigation was designed primarily to answer the question: Is it possible to program the selection mechanism of one of the leading domestic approval plans in such a way that it will automatically supply within certain categories a high percentage of the titles that would have been acquired by a given library through conventional acquisition methods, and at the same time screen out a high percentage of titles that would not have been selected through conventional methods? The study addresses the question of general adaptability of such a program to the existing pattern of book selection in a medium-sized library.

In Raney's study, he states that "it would seem reasonable to conclude that the adoption of an approval plan would not per se result in better book selection or an improved acquisition program at the participating library, although the potential for both would seem to be present in the program simulated in the study. If an approval plan were entered into after a thorough review of strengths and weaknesses of the library collection, if in the process an effort were made to correct deficiencies of the present selection mechanism, if librarians and faculty members worked jointly in developing the library profile, if flexibility of the dealer's profiling technique were fully exploited, if titles pre-selected by the approval system were reviewed with the same discrimina-

\section{Opponents maintain that the mass purchasing plans tend to produce canned libraries.}

tion that is applied to other library acquisitions, and if libraries and/or faculty members continue to select appropriate titles which are not covered by the approval system, then the approval program could serve as a focal point for overall improvement in the selection and acquisition effort. $^{n_{4}}$

Approval plans are an established method for the acquisition of books and have been made a part of many academic libraries' acquisitions programs. An approval plan can be a collection development tool that begins in the acquisitions department. The acquisitions role is emphasized in two results of the study done by Kathleen McCullough, Edwin Posey, and Doyle Pickett: "that $3 / 4$ of the librarians responding said their plans were initiated because they were believed to be an efficient acquisitions tool and that acquisitions department personnel were involved in initiating the plans nearly $60 \%$ of the time as contrasted with collection-development personnel, less than $20 \%$ of the time. Because of the ultimate function of an approval plan, the collection development role should be strengthened both in practice and in subsequent research and discussion in the literature. ${ }^{m 5}$

Acquisitions is the point at which an approval plan procedure starts; collection development is the piont at which it ends. It is possible, given staff and time, to organize the special procedures needed for an approval plan into a reasonably efficient routine, at least for those procedures that are under the control of the acquisitions department. If the approval plan ultimately serves collection development well, the additional effort needed to administer it is justified.

"The professional staff must become practiced at approval plan apologetics and exegetics and at mediation among the various interested parties: teaching faculty, selection librarians, vendors and processing staff." ${ }^{\text {" }}$ An understanding of approval plans is important to any acquisitions librarian, whether or not he works in depth with such plans. To understand these procedures is to understand some of the important techniques of acquisitions. The financial crunch of the present, which promises to extend into the future, will no doubt mean that the days of the grandly sweeping acquisitions of all appropriate titles in given areas may be over. On the other hand, the continuation of approval plans with carefully constructed profiles, limited and and closely defined, can serve as a viable method of collection development if they are constantly monitored to assure that the profile reflects the needs of the institution and if selection is done systematically and conscientiously with the user in mind.

\section{References}

1. Leon Raney, "An Investigation into the Adaptability of a Domestic Approval Program to the Existing Pattern of Book Selection in a Medium-Sized Academic Library" (Ph.D. dissertation, Indiana University, 1972), 2.

2. Raney, 3 .

3. G. Edward Evans and Claudia White Argyres, "Approval Plans and Collection Development in Academic Libraries," Library Resources and Technical Services 18 (Winter 1974): 41 ,

4. Raney, 243.

5. Kathleen McCullough, Edwin D. Posey, and Doyle C. Pickett, Approval Plans and Academic Libraries (Phoenix: Oryx Press, 1977), 124.

6. McCullough, et al., 131. 


\title{
Faculty vs. Staff Selection: Collection Development in the Academic Library
}

\author{
Eugene Huguelet
}

Several questions come to mind immediately when considering what should be the most productive method of managing the development of an academic library collection (i.e., the process of fund allocation and item selection): "How can this activity, which takes place in a very complex organization, be reduced to a list of acceptable guidelines that will allow for a consistent approach to collection growth?" "Have basic principles governing this process in academic libraries been established and proved valid?" "Since every academic library operates, or should operate, to fulfill the particular needs of its parent institution, could a set of general principles serve the individual library as it works to establish its unique collection development strategy?" "Where should collection development responsibilities reside, with faculty or with librarians?"

Most academic librarians have more than likely considered these and many other relevant questions, and some have developed firm ideas (solutions?) that they feel should guide year-toyear, or decade-to-decade, collection development programs. All have, of course, qualified their answers with what are perhaps the primary variables in all such considerations: size and history of the library; characteristics of the institution that the library serves; and the existence of cooperative arrangements, potential and/or actual, with other libraries. Many would probably agree that, even in these days when the automation of library operations appears to be the foremost topic under consideration in the literature and in operating budget requests, the most important question, considering its implications for library success or failure, still concerns the way a library proceeds to develop the most efficacious local collection of materials for the academic community that it serves. Certainly no other question confronting an academic library deserves more professional attention, effort, and (oine hopes) insight. Computer-based operations are no doubt desirable and unquestionably necessary, especially in larger libraries; but it helps to be reminded that the basic measure of a library's

Eugene Huguelet is Director of the William Randall Library at the University of North Carolina at Wilmington. effectiveness has been, and will be, the quality of its own collection in terms of its stated mission.

In view of the apparent complexities and uncertainties underlying the collection development process, how should a library go about this most vital process? Or, to put the question another way, what should be the basic premise in any policy developed to guide the use of given resources to accomplish the goal of achieving the most effective collection possible-a "balanced" collection that will satisfy adequately the most immediate needs of the academic community? Regardless of the size of an academic library, it appears obvious that effective collection development should be based on a policy that establishes, in concrete terms, a cooperative effort among faculty, librarians, administrative staff, and students. Each of these four components of the academic community should have an explicit procedure for adding titles to the collection easily and with a minimum of bureaucratic delay. With each of these groups participating in title selection, the collection will grow according to the current needs of the community for which the library operates. It is probable that a collection development system based on such a broad community of involved participants will result in a collection that reflects the particular interests and strengths of the institution's research and instructional program.

It is difficult to see how the academic library collection can remain an effective tool in the educational program without systematic title selection by faculty in each discipline that the library must support. It is especially important for faculty to concentrate their selection efforts on the acquisition of current publications. Regardless of the bibliographical expertise of librarians in a given discipline, they cannot always remain aware of current research and instructional directions taken by the individual faculty members working in the discipline. It is true that some academic departments are, at certain points, less interested than others in building the library collection; however, this situation can be countered by a persistently strong library effort to encourage the slower departments to participate effec- 
tively. More importantly, it is also true that, given by policy a large share of the responsibility for determining what their library contains, the large majority of faculty will contribute willingly and effectively to the library's collection development program.

\section{Allocation Process}

In libraries where funds for new materials are limited, academic departments or schools must receive an annual allocation for new materials; and this allocation process can be one of the most difficult tasks faced by the library director. Perhaps the most effective method-one that allows the library the year-to-year flexibility that it requires-is to have allocations determined by the library director in consultation with the chairperson of the faculty library committee, reviewed by the entire faculty library committee, and with a final review by the chief academic officer of the institution.

Equally important in the collection development process is the contribution of the library's professional staff, especially those who are assigned to the public services areas. Because of their daily interaction with users, public services librarians are in an excellent position to develop an in-depth awareness of the degree to which the collection responds to current needs and requirements. Making sure that the collection is responsive to users' needs should be one of their most important ongoing duties. Given their particular vantage point for a detailed knowledge of the total collection, this group is perhaps in the best position to make the most effective retrospective purchasing decisions. Definite annual allocations should be made available for this group in order to formalize and facilitate their work in the selection process. It is crucial that public services librarians accept responsibility for developing and maintaining an ongoing dialogue with faculty in all matters pertaining to the collection development effort. If librarians are indeed partners with the faculty in the educational process, this cooperative effort in collection development will proceed as an inevitable outcome of their collaboration.

A procedure for acquiring materials required by the administrative staff of the academic community should be established and made readily available. Allocating funds directly to this large, varied group, which is usually outside of the regular library-faculty communications channels, might be impossible; therefore, the library director should plan to have a fund available for this purpose. A large effort should be made to communicate to this group the library's responsibility to serve its needs as well as the needs of the instructional staff and students. Ordering and notification procedures should be explicit, and a persistent effort should be made to encourage administrative staff to contribute to the collection development program.

The academic library should always establish a definite procedure for receiving and acting upon title requests submitted by students. Of course, many student recommendations may prove to be inappropriate for the collection; however, a very large number will be highly desirable titles that were overlooked by faculty and librarians. Very few public relations activities can generate more goodwill toward the library than inviting students to have an active role in the development of the library's collections. This policy can lead more and more students to refer to the library as "our" library rather than "the" library-a development that can only help the library in its effort to remain the center of the intellectual life of the student body that it serves. Student recommendations can be received in a suggestion box located in a heavily-used part of the library or through the public services librarians who work with students on a daily basis. It also helps to have a library director whose office is easily accessible and always open for discussions of new titles with enthusiastic, motivated students.

If it is accepted that effective academic library collections can be best developed through a well-coordinated cooperative effort by faculty, librarians, administrative staff, and students, what kind of collection development policy should govern the process? It would seem advisable to establish a policy that concentrates on facilitating this cooperative effort rather than to emphasize, for example, numbered levels of purchasing activity among the various Library of Congress classification groups. Over the years, given such a cooperative joint effort, the "balanced" collection-that is, a collection that adequately satisfies the general requirements of the total academic community-will begin to take shape. At least the library might be assured that, to a certain extent, the collection is growing in direct response to current user requirements for informational resources. The level of success achieved in fulfilling these requirements is the primary measure of the effectiveness of the academic library's contribution to the educational program of the institution. 


\title{
The System of Allocations from the Book Budget at UNC-G
}

\author{
James H. Thompson
}

\section{The Criteria}

Roughly 25 per cent of the book budget at the University of North Carolina at Greensboro was designated in 1984-85 for allocation to the academic departments for their use in ordering books and new serials subscriptions for the library ( $\$ 260,430$ of a total book budget of $\$ 1,045,201)$; the remaining 75 per cent was retained for allocation within the library. Eleven criteria have been accepted by the university's Faculty/Student Library Committee as factors to be used in these departmental allocations. These criteria are as follows:

1. The strengths and weaknesses of the collection in the different disciplines as defined by the library's Collection Development Committee.

2. Consideration of an annual statement of library needs described in general terms by each department head or dean and submitted to the library director each spring. In this statement of needs, the department head or dean describes new research emphases, new faculty with differing research needs, the adequacy or inadequacy of past allocations, and the like, which he or she wishes to be considered in the coming year's allocation.

3. Spending patterns in the recent past in the various disciplines as reported by the Acquisition Department. From this report it is determined whether departments and schools have encumbered all of their allocation in previous years and whether they have shown the need for more book funds or less.

4. The number and level of degrees offered in the various disciplines and the number of degrees awarded.

5. New degree programs and areas of study being planned or recently adopted.

6. Increase or decrease in the number of credit hours offered by each school/department at both the undergraduate and graduate levels based on studies received from the Office of Institutional Research.

James H. Thompson is Director of the Jackson Library at the University of North Carolina at Greensboro.
7. Degree of reliance of the school/department on library materials.

8. The effect of joint-ordering, which often supplements cross-disciplinary programs.

9. The supplementing of subject areas by library ordering from the library general and standing order funds.

10. Attention to excessive costs of library materials using average per-volume prices of hardcover books from Publishers Weekly, the Library of Congress, and vendors.

11. Amount of continuing library funds realized by schools/departments for ongoing serials in their disciplines from the built-in serials budget of the library.

\section{The System}

The library fiscal year extends from July 1 to June 30 of each year, but the book ordering or encumbrance year begins on March 1 of each year and continues to the end of February of the next year. The reason the encumbrance year ends on February 28 is that in a world-wide book ordering program, it takes the remainder of the fiscal year to receive all books and invoices and pay all bills by June 30 , as required by the state. A department may begin ordering from its allocation on March 1 of each year (the encumbrance year's accounts having been closed for the preceding year the day before) even though the exact amount of one's allocation is not known until budget figures for the next fiscal year are released the next July. It is a reasonable assumption to conclude by March of each year that the book funds available for the next fiscal year will not be substantially less than in the present year. On the other hand, to be certain that there are not excessive encumbrances in the spring and early summer, no department is allowed to encumber more than 65 per cent of the amount represented by the present year's allocation before September of the following summer, at which time a second allocation is made. This second allocation completes the commitments from a book budget that by that time (September 1) is known in detail. In July of each year, at the beginning of or shortly 
after the start of the new fiscal year, exact budget figures are announced for the new fiscal year. These figures are usually quite close to the projected figures estimated in February and March of the previous year (the beginning of the book ordering year), because in the first year of a biennium the budget recommendations of the Governor and the Advisory Budget Commission have been published by February and in the second year of the biennium the biennial budget has already been tentatively approved by the previous session of the General Assembly. With these firm figures in hand, the library director is then in a position to allocate the remaining book funds at the beginning of the fall semester.

These two allocations guarantee balanced book ordering over the course of the entire year since funds are made available in the spring and in the fall. Moreover, there is the stipulation that a substantial portion of a department's allocation must be encumbered in a given book ordering year (March 1-February 28) by December. If that is not the case, a department may lose funds, which will then be transferred to other needs. Funds not encumbered fully by February 28 revert automatically for immediate reassignments. The allocated funds may be used by the departments for the ordering of new books or new serials subscriptions. The initial one, two, or three year subscription for serials is taken from the department allocation; the continuing costs are absorbed in the Serials Fund, a part of the ongoing built-in funds retained by the library.

\section{The Procedures}

The university's Faculty/Student Library Committee, on recommendation from the library director and the Collection Development Committee of the library, allocates to each academic department 65 per cent of its previous allocation at its meeting in late February of each year. This amount is intended to satisfy the needs of the departments until the next September 1 at which time the second allocation will be made, exact budget figures then being known. Before the end of the spring semester, each academic department head submits to the library director a statement of book/serials needs for the next year expressed in general terms. In this statement of needs, a number of issues are addressed (new programs, adequacy of last year's allocation, new faculty and new specialties, the changing nature of the discipline). The library director also requests a study of credit hours (undergraduate and graduate) offered that year by each depart- ment compared to the previous year from the Office of Institutional Research. Shortly after the beginning of the fiscal year, July 1 , the Collection Development Committee of the library meets to examine these documents, in addition to internal statistics and reports and its own perceptions, and to recommend to the library director the second and final allocations for the year. The Collection Development Committee applies the eleven criteria cited above. The library director, after his examination of these recommendations,

Faculty participation in collection building is a healthy sign of faculty interest in the library and is something to be encouraged.

passes them on to an Allocations Subcommittee of the university's Faculty/Student Library Committee. Very early in the fall semester, around September 1 , these recommendations are taken to the full library committee at its first meeting of the year for approval.

Each academic department appoints a library representative who coordinates book and serial ordering in that department and countersigns each order card. Some departments have library committees that meet and regularly discuss library matters, but the formal contact between the library and the academic departments is the department's library representative. Monographic orders are sent directly to the acquisitions department; serial orders are sent to the Serials Department and ordered only after full justification for need has been examined along with sample copies by the Collection Development Committee.

There are built-in commitments retained by the library that are, in effect, library allocations. These funds are the serials fund for ongoing subscriptions, roughly 50 per cent of the total book budget; the library general fund for the ordering of current monographic publications in all disciplines to assure that the major output of the leading publishers is acquired each year; the collection development fund for the purchase of retrospective material used mainly in filling in gaps in the collection; the reference fund for the purchase of reference books; the documents fund for the purchase of currently published nondepository documents and retrospective sets; the replacements fund; the library director's contin- 
gency fund for the acquiring of high priority items that become available unexpectedly for a limited period of time; and the standing order fund for purchasing of books from the major university presses and other publishers with whom the library has standing orders. As stated above, these built-in commitments consume roughly 75 per cent of the total library book budget.

Each departmental library representative and each librarian responsible for one of the internal allocations receives a monthly accounting record from the head acquisition librarian reporting his department's encumbrances and expenditures to date.

\section{An Assessment}

The criteria and procedures described above may seem complex, but actually they fall into place very easily over the course of the year. The allocations system takes time because it is subjective in that neither an automatic formula nor traditional allocated amounts are used. On the other hand, the system is fair in its subjectivity, and it has the flexibility of changing from year to year as the programs and priorities of the university change. Some universities have passed in recent years from a shared faculty-library ordering system to one which relies entirely on library bibliographers. It is the feeling on both sides at UNC-G that faculty participation in collection building is a healthy sign of facuity interest in the library and is something to be encouraged. The interchange between faculty library representatives and library staff is an important part of the collegiality evident at this university between the teaching faculty and the library, and it provides to a very important group of faculty an insight into the work of the library staff. This close feeling and understanding has resulted, in part, in such benefits as meaningful faculty status for professional librarians, the election of librarians to important positions in faculty government, and the very supportive role of the university's Library Committee for the program of the library rather than an adversarial role as is the case on some campuses. Some may say that this conclusion overstates the importance of this shared librarian/ faculty responsibility, but I would argue, having watched the system develop over the last fifteen years, that collaborative efforts such as this do indeed engender a sense of equality and respect from the teaching faculty for the librarians.

Other benefits of the system include the commencement of the book ordering year from March 1 instead of September 1 ensuring that book ordering over the course of the year is balanced and consistent, with several checkpoints (September 1, December 1, February 28) to verify that all funds are equitably and fully encumbered and spent on time. Theoretically the Library Committee of the university has the authority to allocate the book budget, but in practice it has never questioned to any significant degree the recommendations brought to it by the Collection Development Committee of the library and the library director. In effect, therefore, the system is controlled by the library staff and director.

In conclusion, the allocations system at UNC-G, which developed experimentally over the early and mid $1970 \mathrm{~s}$, has reached a level of fine tuning which now meets the needs of a mediumsized research university.

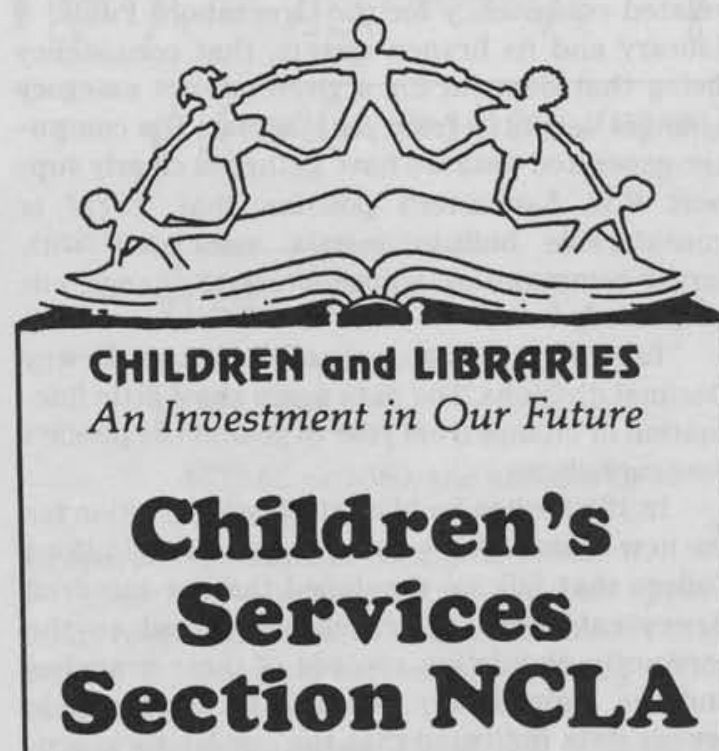

Is currently selling notepads for $\$ 1.00$. Proceeds will go to pay program expenses for the Oct. '85 NCLA Conference.

The pads are $81 / 2 \times 5 \frac{1}{1 / 2}$, have 50 pages each, and are available in pink, green \& yellow.

Order from: Rebecca Taylor

College Sq. Branch Library

330 S. College Rd.

Wilmington, NC 28403

$\$ 1.00+50 \$$ postage and handling. 


\title{
Computers and Collection Development
}

\author{
George B. Viele
}

Collection development, book selection, the acquisition of materials-what is it all about? At the Greensboro Public Library we have been attempting to establish or maintain book collections that reflect actual use. Our endeavors are based on computerized circulation records for a four-year period.

Table I shows actual user demands as a per cent of the non-fiction circulation of selected individual Dewey Decimal categories. It should be noted that all non-fiction categories show one related consistency for the Greensboro Public Library and its branch system, that consistency being that demand for a given subject category changes very little from year to year. The computer-generated data we have gathered clearly support F.W. Lancaster's position that "there is considerable built-in inertia associated with larger communities" whose interests change, but very slowly. ${ }^{1}$

Table II presents usage of five of ten Dewey Decimal divisions. The data again show little fluctuation or change from year to year in the public's reading habits.

In 1983, when building the book collection for the new branch that was to be opened in Guilford College that fall, we developed the one hundred Dewey categories percentagewise based on the composite circulation records of three branches and the main library. A study of demographic census data indicated that the similar socio-economic data of that community warranted the approach taken. In other words, the amount of shelving space for each Dewey Decimal division and the per cent of non-fiction books in each of the one hundred categories were determined by our circulation-usage study.

The use of a computer in any facet of collection development or maintenance results in a constellation of considerations for the librarian. The basic consideration, however, is buying books that reflect the actual demands of borrowers. Usage data can easily be computer generated. It can also, of course, be done manually.

George B. Viele is Director of the Greensboro Public Library.
Raw data, regardless of how obtained, must be organized or compiled in some way that will facilitate usage. Consequently, we add the circulation for the one hundred non-fiction categories, compute the average or mean, and find the standard deviation for each category.

A balanced book collection is brought closer to reality when past usage data serve as a basis for allocating money for books. Believing this, the writer developed a book budget formula for determining how much book monies are to be spent for the various non-fiction areas at the Greensboro Public Library. The formula involves the use of the following:

1. The standard deviation of each of the nonfiction categories.

2. The sum of all the standard deviations of all one hundred categories.

3. A percentage of the total monies allocated for books at the Greensboro Public Library.

4. The average cost per hardback volume per subject category (source - The Bowker Annual).

5. The total number of hardback volumes published per subject category (source The Bowker Annual).

6. The total value of all hardback volumes published (source - The Bowker Annual).

The book budget formula for categories of one standard deviation or more is:

$$
\sqrt{\left[\left(\frac{\sigma \mathrm{DC}}{\Sigma_{\mathrm{ADC}}}\right)(\mathrm{M})\right]\left[\left(\frac{(\mathrm{A}) \mathrm{V}}{\mathrm{TC}}\right)(\mathrm{M})\right]}
$$

where:

$\sigma=$ The standard deviation

$\mathrm{DC}=$ The Dewey Decimal category

$\Sigma=$ The sum of all Dewey Decimal categories

$\mathrm{M}=$ Money for non-fiction at the Greensboro Public Library

$A=$ Average cost per volume in a subject category

$\mathrm{V}=$ Number of volumes published in a subject category

$\mathrm{TC}=$ Total cost of all volumes published 
TABLE 1

Location - Benjamin Branch

(In per cents)

\begin{tabular}{lcccc}
\hline Category & 1980 & 1981 & 1982 \\
\hline $790-799$ & 9.3 & 8.5 & 8.1 & 7.6 \\
$610-619$ & 6.9 & 7.0 & 7.0 & 2.7 \\
$330-339$ & 2.4 & 2.5 & 2.5 & 5.4 \\
$910-919$ & 5.6 & 5.2 & 3.1 \\
$810-819$ & 3.1 & 2.7 & 3.0 & 3.1 \\
\hline
\end{tabular}

By taking the square root of the products found we are able to balance out any unusual variations that may exist in a given area, which, if not compensated for, would distort or unduly influence the allocation for a given subject category. Examples of possible variations include an unusually high average cost per volume, an exceedingly large number of titles published in a given subject category, or high actual circulation as compared to other categories.

Here is an example of the formula at work. In 1984 the Greensboro Public Library was allocated $\$ 50,000$ for the general book collection. In calendar year 1983, 84.3 per cent of the adult circulation at the library was non-fiction. Thus $\$ 50,000$ times .843 gave the amount to be spent for non-fiction, namely, $\$ 42,150$.

The top fifteen demand categories constituted 45.08 per cent of all non-fiction circulation. Multiplying .4508 times $\$ 42,150$ produced a product of $\$ 19,000$, which is the "M" in the formula.

The sum of the standard deviations for categories one standard deviation or more above the mean was 24.4. The sports/recreation category, $790-799$, was 2.65 standard deviations above the mean. Plugging the 2.65 and the $\Sigma 24.4$ into the formula, we have

$$
\left[\left(\frac{2.65}{24.4}\right)(\$ 19,000)\right]
$$

The remaining data were obtained from a table on page 375 of The Bowker Annual, 23rd edition. The table showed the average per-volume prices of hardcover books for the years 1977-1982.
Looking under the sports/recreation category, we found that the total price for this category (average cost times number published) was in 1982 $\$ 9,159.99$. The grand total price for all non-fiction books in 1982 was $\$ 738,724.98$. Using these figures, we end up with the formula being completed.

$$
\begin{gathered}
\sqrt{\left[\left(\frac{2.65}{24.4}\right)(\$ 19,000)\right]\left[\left(\frac{\$ 9,159,99}{\$ 738,724.98}\right)(\$ 19,000)\right.} \\
=\sqrt{[(.1086)(\$ 19,000)][(.012)(\$ 19,000)]} \\
=\sqrt{(2,025.4)(228)} \\
=\sqrt{461,791.2} \\
\quad \begin{array}{l}
\$ 679.55 \text { or } \$ 680, \text { the amount to be } \\
\text { allotted }
\end{array}
\end{gathered}
$$

for sports/recreation in fiscal year 1985 .

Using the Viele formula, we have an opportunity to spread the book budget in a manner that assures the eventual success of achieving a balanced book collection.

Does this writer recommend this formula to other librarians? The answer is an absolute no! The calculations are long (not hard) and time consuming unless the librarian uses either a calculator or a computer to do the computations. But, perhaps, once every ten years down the trail of book acquisitions would be worthwhile.

TABLE II

Location - Benjamin Branch

(In per cents)

\begin{tabular}{lcccc}
\hline Category & 1980 & 1981 & 1982 & 1983 \\
\hline 700 's & 23.8 & 22.1 & 21.0 & 22.3 \\
600 's & 25.2 & 27.0 & 28.0 & 27.6 \\
300 's & 14.2 & 13.5 & 13.8 & 13.8 \\
900 's & 15.7 & 16.7 & 16.1 & 16.2 \\
800 's & 7.4 & 6.7 & 6.8 & 6.9 \\
\hline
\end{tabular}


You will never know until you take that first great step toward building better balanced book collections through computer-generated data and mathematical formulas applied to book budget allocations.

\section{References}

'F. W. Lancaster, "Evaluating Collections by Their Use," Collection Management 4 (Spring/Summer 1982): 16.

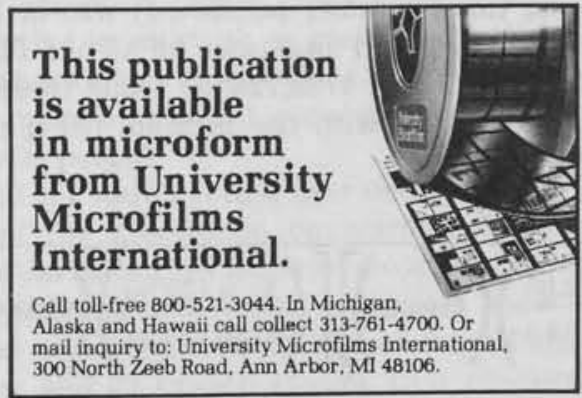

\section{Cape Fear Union List of Serials}

The sixth edition (1984) of the Cape Fear Union List of Serials is now available. The Union List includes approximately two thousand serials titles held by Cape Fear area libraries, including Fayetteville State University, Fayetteville Technical Institute, Command Reference Center and Main Post Library (Fort Bragg), Methodist College, Pembroke State University, Base Library (Pope Air Force Base), and Cumberland County Public Library and Information Center.

CFLA would like to extend special thanks to Barbara Beattie, Cape Fear Valley Medical Center, for her work in compiling this year's list. The list is available for $\$ 7.00$. Orders may be sent to

Cape Fear Library Association

c/o Barbara Beattie

Library Services

Cape Fear Valley Medical Center

P.O. Box 2000

Fayetteville, NC 28302

An invoice will be mailed along with the list.

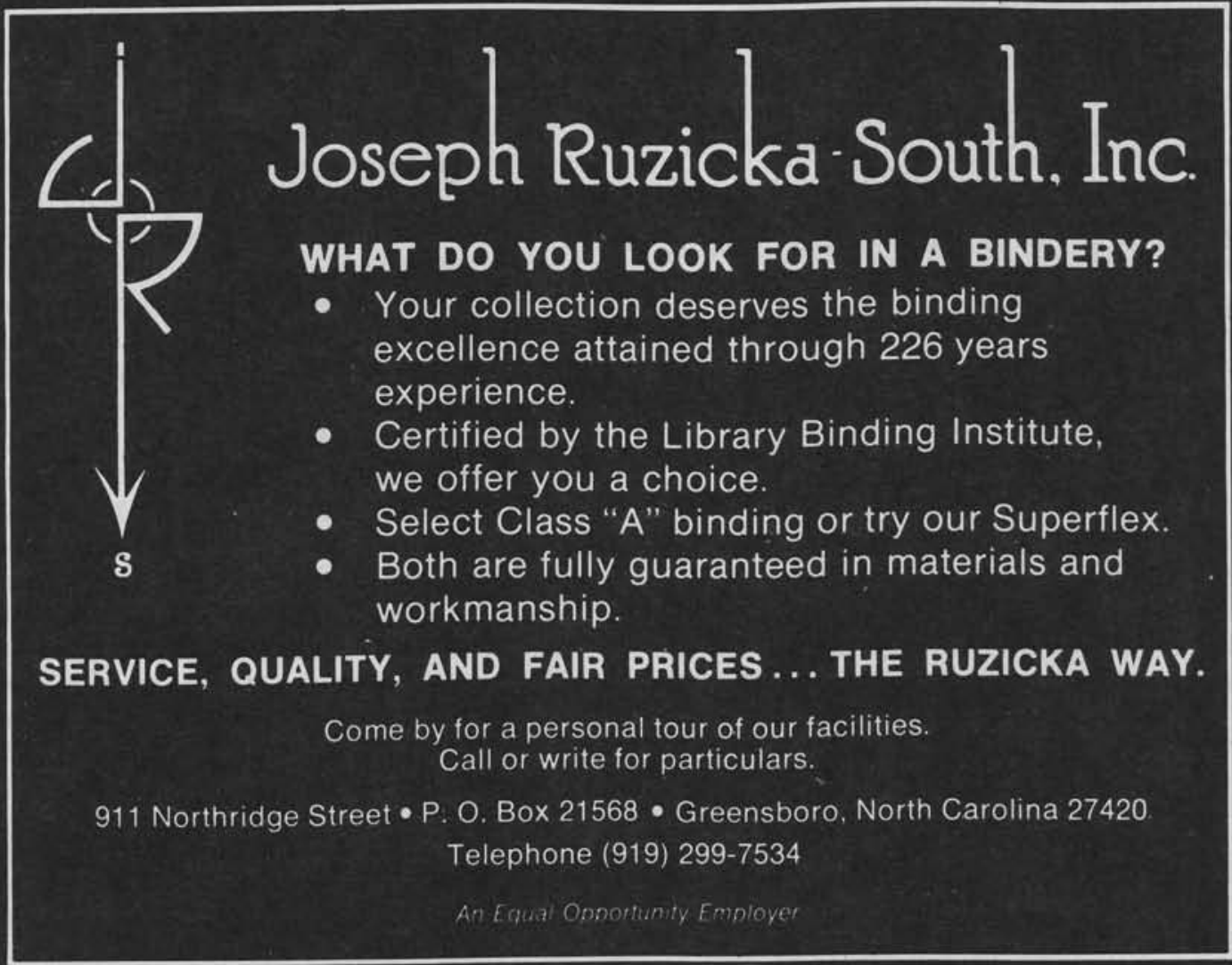




\title{
Building a Serials Collection in an Academic Library:
}

\author{
Joline R. Ezzell
}

One observation about building a serials collection in an academic library that can immediately be made is that it is a very difficult task. Or to be more precise, it is difficult unless the library has enough financial support to purchase all the serials that are wanted and needed for the collection. In view of the number of titles published worldwide and the costs of these titles, are there any academic libraries so endowed today? Assuming that there are not, all of them will find themselves having to choose between title $\mathrm{A}$ requested to support academic department $\mathrm{X}$ and title $\mathrm{B}$ recommended to enhance a course taught in department $\mathrm{Y}$. These are tough choices that must be made on other than a subjective basis and that must be justified.

Part of the difficulty of selecting serials for the collection stems from the very nature of these publications. They are ongoing and so is the commitment made when a decision to subscribe is reached. When new serials are added to the collection, the length of the list of titles on subscription increases as does the amount of money expended for them. Without regular review and evaluation of the serials collection, resulting in cancellation of titles deemed no longer necessary to the institution's objectives, the expanding serials budget can result in reduced funds available for the purchase of monographs. Each library should have such a program of regular evaluation of its serials on subscription, to judge whether they remain useful to the institution's courses of instruction. If the initial selection has been made without the benefit of a sample issue, such examination is even more important. Many journals change title, issuing body, frequency, or subject matter over time; some do it within the first year, so that volume 1 , no. 4 , may be quite different from volume 1 , no. 1 , which was the basis for the decision to subscribe. In many academic libraries, the subscription continues automatically, despite both these changes and a steady increase in the subscription price; titles continue to be received and housed when they

Joline R. Ezzell is Head of the Serials Department at the Duke University Library in Durham. may no longer be appropriate for the collection. Evaluation of the serials collection often comes only when forced by budget restrictions that necessitate the identification of titles for cancellation in order to buy new serial titles or monographs.

Building the serials collection is hard work, then, because of the decisions that have to be made and because, in most cases, of their lasting impact. The task may be more difficult because of the lack of a sufficient number of knowledgeable personnel to select materials from all disciplines in which classes are taught and research is done. Cullection development, in the strict sense of the phrase, may be a myth in many libraries. For those that have had neither collection development staff adequate to select materials consistently in all subject areas over the life of the library nor written collection development policies and guidelines, the serials collection may be a product of the particular interests of the selectors, be they faculty or staff. The quantity, as well as the quality, of the serials collection in any particular discipline will be a result, in large measure, of the interest or disinterest of the selectors.

\section{Faculty Selection}

In past years, much of the collection development in academic libraries was done by faculty members, who took great interest in this activity and conscientiously built the library's collection in their subject areas. The majority of the present generation of faculty, however, do not consider the selection of library materials to be their responsibility and find themselvẹs too busy with other duties to recommend materials for library purchase on a regular basis. Their selection is limited to an occasional title needed for course reserves or their own research. The responsibility for collection building, then, becomes the library's. In many institutions where selection of materials was primarily an activity of the faculty, library staffing is not sufficient ot take on this extra duty. Staff time borrowed from the reference, circulation, or cataloging departments is likely to be inadequate for consistent, thorough collection building. A knowledgeable, thoroughly trained 
staff sufficient in numbers is required for this most important task. Identification and selection of serial titles is time-consuming and requires staff members the majority of whose time is dedicated to collection development activities. The selection, optimally, should be done by those who have taken the time to gain a feel for the total library collection-its strengths and weaknesses and its special collections.

Identification of new serial titles requires good communication with serial publishers who will be willing to send announcements of new journals in the library's fields of interest as well as sample copies. It requires reading the library

\section{Serials are ongoing and so is the commitment made when a decision to subscribe is reached.}

literature, which frequently carries announcements of forthcoming publications, and the literature in the subject area for similar information. Interested faculty can also be helpful in alerting the library to new journals that they have learned about through colleagues who are serving as editors or authors. Though sources of reviews of new journals are few, they can be helpful as well.

Assuming that provisions can be made for the recommendation of serial titles to be added to the collection, where does the final decision-making responsibility lie? Is everything that is recommended ordered? Most likely not, unless the library is extremely well endowed. Because of the ongoing commitment made when a serial subscription is placed, review of recommended titles is usually more rigorous than that given to recommended monographs. There are a variety of options for making final decisions. Recommendations of faculty may be accepted automatically, whereas those of library staff may be reviewed. Final decisions may be made by one or more collection development officers, by a committee of library staff, or by a committee composed of library staff, students, and faculty. Whatever the mode chosen, the goal must be to provide a serials collection that supports the teaching and research needs of the academic institution-easy to say but much more difficult to effect when faced with decisions to be made about individual titles.

\section{Questions}

Some of the questions that each person charged with the responsibility of selecting from among recommended serial titles must answer are the following: Does the library collect materials of this type of in this subject area (e.g., newsletters, Oriental music)? To what extent does it collect them? Will this title help to provide balance of opinions on this topic? Are there existing cooperative collection development agreements with other libraries that will affect this decision? Do we receive other serials on this subject that could be cancelled in exchange for this one? What is the quality of this title in relation to the others dealing with the same subject? What is the actual use of the other library titles on this subject? Does the college or university plan to develop a program of instruction in this subject area? Does the college or university plan to reduce the enrollment in this discipline? What courses would this title support? How many titles of this type (e.g., regional literary magazines) are needed in the collection? How many, and which, recreational magazines are needed in the periodical collection? Where is the journal indexed? Should the serial be retained permanently? Can the issues be bound, or are they made of newsprint? Should they be retained in paper copy and bound? Is microform available? Should the title be retained permanently only on microform? If it is published in a foreign country, should air mail delivery be requested?

The basic determination to be made through the posing of these questions is the value of a particular serial in relation to its cost, the other serials to which the library subscribes, and the institution's programs of instruction. Some of the questions may be answered in written, regularly

\section{Collection development, in the strict sense of the phrase, may be a myth in many libraries.}

updated collection development policies. Those concerning the plans of the institution can be answered through good communication with the college or university administration. Questions of the title's usefulness to particular academic departments can be answered through consultation with faculty members, who are usually quite willing to provide advice concerning specific serials even when they are not able to do selection themselves. Having an active library representative in each teaching department can be quite useful in this regard.

Some librarians have predicted that the serial as known today will not exist in the future. ${ }^{1}$ They believe that journals will be published only 
electronically. Those librarians who now focus their attention on building serial collections will instead in the future assist patrons in searching electronic databases for needed information, according to this scenario. One writer predicted in 1980 that it would be at least five years before there was any major shift from printed to electronic journals. ${ }^{2}$ Considering the progress made to date and the many questions remaining to be answered about electronic journal publishing

\section{Staff time borrowed from the reference, circulation, or cata- loging departments is likely to be inadequate for consistent, thorough collection building.}

(copyright; rewards, both tangible and intangible, to authors; and standards for telecommunication), it is likely to be at least another five years before such a shift is made and unlikely that all serials will be published electronically. In the meantime, even as we plan for the utilization of electronic journals in academic libraries, we will continue to build serial collections. Consequently, we will continue to need individuals with good judgment, who are knowledgeable in the subjects in which they select, familiar with the existing collection, and alert to new or revised institutional programs. Serving as the foundation to this entire process is a comprehensive, frequently revised collection development policy.

\section{References}

'Meredith Butler, "Electronic Publishing and its Impact on Libraries: A Literature Review," Library Resources and Technicial Services 28(January/March 19840: 41-58.

${ }^{2}$ A.E. Cawkell, "Electronic Information Processing and Publishing-Problems and Opportunities," Journal of Information Science 2(October 1980): 192.
Instructions for the Preparation

\author{
of Manuscripts
}

\author{
for North Carolina Libraries
}

1. North Carolina Libraries seeks to publish articles, book reviews, and news of professional interest to librarians in North Carolina. Articles need not be of a scholarly nature, but they should address professional concerns of the library community in the state.

2. Manuscripts should be directed to Robert Burgin, Editor, North Carolina Libraries, School of Library Science, N.C. Central University, Durham, N.C. 27707.

3. Manuscripts should be submitted in triplicate on plain white paper measuring $81^{1 / 2} \times 11^{\text {" }}$.

4. Manuscripts must be double-spaced (text, references, and footnotes). Manuscripts should be typed on sixty-space lines, twenty-five lines to a page. The beginnings of paragraphs should be indented eight spaces. Lengthy quotes should be avoided. When used, they should be indented on both margins.

5. The name, position, and professional address of the author should appear in the bottom left-hand corner of a separate title page.

6. Each page after the first should be numbered consecutively at the top right-hand corner and carry the author's last name at the upper left-hand corner.

7. Footnotes should appear at the end of the manuscript. The editors will refer to The Chicago Manual of Style, 13th edition. The basic forms for books and journals are as follows: Keyes Metcalf, Planning Academic and Research Library Buildings New York: McGraw, 1965), 416.

Susan K. Martin, "The Care and Feeding of the MARC Format," American Libraries 10 (September 1979): 498.

8. Photographs will be accepted for consideration but cannot be returned.

9. North Carolina Libraries is not copyrighted. Copyright rests with the author. Upon receipt, a manuscript will be acknowledged by the editor. Following review of a manuscript by at least two jurors, a decision will be communicated to the writer. A definite publication date cannot be given since any incoming manuscript will be added to a manuscript from which articles are selected for each issue.

Issue deadlines are February 10, May 10, August 10, and November 10.
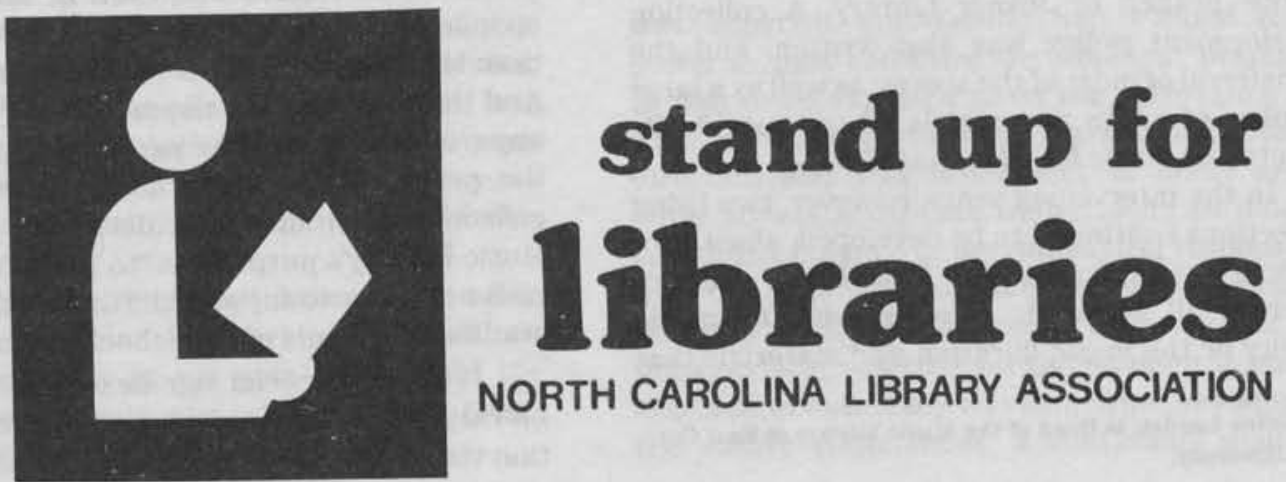

NORTH CAROLINA LIBRARY ASSOCIATION 


\title{
Development of a Collection: The Music Library at East Carolina University
}

\author{
Geraldine Laudati
}

Although seven years' experience (which included primary responsibility for material selection and budget management in music libraries) preceded my appointment as music librarian at East Carolina University in 1982, I was surprised at the extent of challenge presented by the rather small special collection. At the core of the problem was the Music Library's history and its unique position as the university's sole branch library.

As is the case with many academic special collections, the Music Library began as a departmental collection: the School of Music purchased sound recordings and some scores, typically of the 'performance edition' genre, and housed them in the department, where they would be more readily available to music faculty and students. At the same time, Joyner, the university library, collected and housed most monographs and serials about music and some scores, including many of the large and expensive collected works editions and anthologies. The situation was altered as a result of the 1973 accreditation visitation by the National Association of Schools of Music, which recommended consolidation of music materials into a single collection. The School of Music was the recommended repository site due to the physical distance-a ten-minute walk across campus-between the school and Joyner Library, and the association justified its choice on the basis of the location's being the most appropriate to the largest community of users.

By 1976 , a branch library policy was drawn up by university administration, and the Music Library was officially designated as an administrative branch of Joyner Library. A collection development policy was also written, and the transferral of most of the scores, as well as a large number of books and serials (those specifically selected by music faculty), was effected.

In the intervening years, however, two living collections continued to be developed, albeit sporadically, simultaneously. The Music Library received all materials recommended by music faculty or the music librarian and materials that

Geraldine Laudati is Head of the Music Library at East Carolina University. fell into the category of "serious" music. Non-serious (ostensibly) music, music-related items recommended by the reference department as part of the collection development process of the university library, and music materials requested by non-music faculty, such as dance or drama, continued to be added to the main library's collection.

Funding responsibilities were equally nebulous, and the annual amount provided by the School of Music (originally intended for the purchase of sound recordings) was being used to pay for serial titles that the main library would not assume. In fact, a study of the funding patterns revealed that library allocations for music materials had declined steadily since the Music Library's branch status, despite a not unhealthy library budget relative to institutional size and a large, active School of Music.

Other problems were evident in the mechanical aspects of collection development. Acquisitions functions for Music Library materialsprocessed centrally by the university library-had seriously deteriorated, and faculty were complaining of three or four year waits for materials and of requests that had simply dropped from sight, never to reappear. Even items documented as having been received were prone to disappear, and the short distance between libraries had assumed the distorted proportions of a black hole.

Finally, and perhaps symptomatic of the underlying problem, the branch collection continued to be referred to, even in official correspondence, as the School of Music Library rather than the East Carolina University Music Library. And the collection development policy, it became apparent on study, was partially responsible for the perpetuation of the library's departmental collection mentality. The document stated the Music Library's purpose as "to provide the materials necessary to support the undergraduate and graduate curricula of the School of Music." Period.

1982 held special significance for the Music Library. Faced within a year with a re-accreditation visit from the National Association of Schools 
of Music, administrators at all levels were deeply concerned with our problems, and a willingness to cooperate towards solution and a sense of direction for the collection were soon evident.

First, an assessment of the potential user community was undertaken and yielded not only the 350 -odd students and 55 faculty members of the School of Music but a campus community of nearly 14,000 FTE students and 800 faculty, including those in active dance and drama departments (located, coincidentally, in an adjacent building), a new medical school, plus a campus radio station with no classical record library, all of whom might depend on the library to satisfy a broad variety of instructional, informational, and recreational musical needs. In addition, the relative geographic isolation of the university placed an extra responsibility to service on the institution, and as a special collection, the Music Library could be expected to provide a unique resource to the eastern region of the state. Indeed, many of our patrons were graduates or graduate students teaching in local school systems and who had access to no other source of musical information.

Armed with the knowledge of the collection's potential, a reinterpretation of the branch library policy was suggested, in particular:

\footnotetext{
The needs of the campus majority (not the branch clientele) are paramount ... While it is perhaps frustrating at times not to have relevant materials close at hand, it is still more frustrating to more people on our campus to have to go from one library building to another in order to pursue study. The assumption that a discipline's materials can be transferred in toto from a central to a branch library without impeding library services is naive...
}

While the statement itself was not invalid, it seemed more naive to assume that anyone was being better serviced as practically all musical study still required the use of both libraries, as did, unfortunately, Music Library reference service. The distinction between School of Music curriculum-related areas and non-curricular areas, furthermore, was a blurred one and somewhat subjective. Finally, but of major importance, was the fact that staff with music degrees were employed in the Music Library, while the main library, understandably, included no one with this subject expertise.

These points were well taken, and while retaining curricular support as the Music Library's first priority, we were able to add the following purposes to our interim, working version of the collection development policy: ${ }^{1}$
The collection should provide a broad base of support for general cultural interests in music and its role in the history of civilization on an international scale;

The collection will provide for interdepartmental academic needs in dance, drama, art, folklore, the study of ethnic and popular cultures, film production, and others as applicable.

The issue of a split collection was thus addressed. A systematic transfer of the music items remaining at Joyner was begun along with an interim practice of housing in the Music Library all items that class in L.C. classification "M" (i.e., M, ML, MT), as well as all sound recordings of musical materials regardless of funding or selector source. $^{2}$

At this point, a publicity campaign was undertaken to acquaint the campus community with the collection and services offered. A Music Library newsletter was begun, and we spoke to various campus groups, Friends groups, committees, and essentially, anyone who would listen. That the campaign was successful and our message received was made evident by two annual allocations from the East Carolina University Student Government Association for the development of a contemporary jazz recordings collection, for use in the Music Library by the campus community.

Ironically, while aggressively promoting the catholic quality of our collection and services, a study of the objectives of the School of Music was concomitantly undertaken to better determine how the existing collection was meeting instructional support needs and how it might better meet those needs. Through conferences with School of Music administration, departmental chairmen, the departments as groups, and finally, with individual faculty members, it was possible to obtain a clearer picture of our strengths and weaknesses, as well as to anticipate future directions which were under consideration.

For a variety of reasons, principal among them the idiosyncracies of funding mechanisms, it was apparent that faculty had wielded much power in past collection development practices, as was to be expected given the collection's history. The existing collection showed little overall direction and was insufficient in many areas. While it was a delicate undertaking to quickly switch the balance of developmental responsibility from primarily user dominated to primarily librarian dominated, it seemed, in my opinion, the most pressing objective for the moment. A potential taint of autocracy was somewhat obviated by the earlier conferences, a continuing dialogue 
between the Music Library and the faculty, and the reassurance that no department's special interests would receive priority except as against the overall needs of the collection.

At this point, a collection assessment project had been completed. Designed to evaluate the present level of the collection and to determine in what ways it was inadequate, assessment was made through use of specialized bibliographies and discographies, by comparison with collections at institutions of similar size, user communities, and programs, as well as on the basis of information gathered from faculty conferences and discussions with graduate and undergraduate students. Gaps were identified, a prioritized desiderata file established by the type of material, and suggestions made as to the extent of retrospective development necessary to bring the collection to a level consistent with our needs and stated purposes. ${ }^{3}$ Areas requiring intensive attention were scheduled into a developmental timetable that will ensure them major concentration in their turn.

With this information, it was little trouble to prepare two documents on the funding requirements of the Music Library. The first, a proposal for limited term special funding for retrospective collecting, was developed on the basis of estimated costs of needed materials. To date, approximately 40 per cent of this proposal has been funded. The second, and more complex, reflected the level of continuation (i.e., annual) funding necessary to maintain the collection. Borrowing the university library's materials allocation plan, which assigned a percentage factor to such data as number of students, faculty, credit hours taught, as well as information from the publishing trade, it was possible to request a more appropriate level of support for each of the material types collected, namely monographs, serials, scores, and sound recordings. ${ }^{4}$ In addition, responsibility for this support between the School of Music and Joyner Library was more clearly defined.

Two and a half years later, the Music Library is well along in its developmental schedule, including retrospective collection, and the results of earlier efforts are readily apparent. The final version of a collection development policy is nearing completion, written with extensive input from the School of Music Library Committee ${ }^{5}$ and faculty, as well as the Head of Collection Development at Joyner Library. ${ }^{6}$ Although library funded music materials continue to be ordered and processed centrally, the working relationship between departments is excellent: as awareness and understanding of the Music Library's special needs increased, so did communication, cooperation, and consequently, service. The eagerly awaited 1983 report of the National Association of Schools of Music identified the Music Library as one of the School's three main strengths, commenting that the institution was well on its way to having an excellent music library and adding its blessing "it is hoped the improvements continue and that the library will become a truly fine one." Less easily documented but of even more significance is the perceptible attitude of understanding, respect, and cooperation that has evolved among the three principal factions directly involved. As a result, the Music Library's role as a branch library is clearly defined, its goals and directions outlined, and its commitment to continued development assured.

\section{Postscript}

The reader with experience in large university libraries or long established special collections will no doubt realize that most of these observations are obvious enough to go without saying. That they needed to be said, and said emphatically, is perhaps an indication that there are yet situations, particularly in smaller institutions, where physical separation, misconception of or ambiguity of purpose, ambivalent commitment, and perceived divided loyalties may operate to the detriment of the branch collection. Often, identification of the problem is the first step to a solution.

\section{References}

1. University of Texas at Austin. General Libraries. Collection Development Policy. 2d ed. (Austin, 1981): Music, was the model from which additional statements of purpose were borrowed. 2. The exception is that music reference tools deemed necessary or appropriate to the Joyner Library reference collection are duplicated by the reference department. As the university collection development policy is in process of revision, many practices have been adopted as interim.

3. Retrospective development here refers to the acquiring of materials, most typically in print, necessary to bring the collection up to a desired level. For the most part, antiquarian materials are generally not required for our purposes.

4. Other factors such as circulation statistics and past development experience were included. While the figures have fluctuated somewhat as work on the collection development policy continues, they provided a base from which to begin.

5. The Music Library Committee was restructured in 1983 to include one facuity member from each of the school's five departments rather than randomly appointment members. Its function also changed to an advisory group charged with dissemination of information.

6 . The position was created in 1984 . Until that time, responsibility for direction of collection development was divided between the reference and acquisitions departments. 


\title{
Collecting North Caroliniana
}

\author{
Alice R. Cotten
}

Selection of material to be included in the North Carolina Collection is very simple-there is no selection. Every book, pamphlet, article, that can be secured, relating to North Carolina, is carefully preserved. ${ }^{1}$

This statement of sixty years ago was the collection development policy for the North Carolina Collection at the library of the University of North Carolina at Chapel Hill from its beginning. It served the collection well, providing flexibility and an "open door" policy for many ephemeral items that otherwise might have been lost. But today one library cannot collect all items relating to every city, town, crossroad, school, organization, business, and organization in the state. Much of this responsibility rests on local libraries. This article will recommend that public and academic libraries actively collect and preserve printed information about local people, events, organizations, institutions, and buildings, and will suggest the need for cooperation among libraries to ensure preservation of North Caroliniana.

The first question is how to define "North Caroliniana." It includes nonfiction and fiction, poetry and prose, monographs, pamphlets, documents (local, state, and federal), maps, newspapers, journals, magazines, annual reports of business, newsletters, photographs, broadsides, dissertations, theses, clippings, recordings, and films about the state, its people, or any of its political, geographic, or social divisions. It can also include material written by North Carolinians, regardless of the subject.

The combined holdings of the North Carolina Collection in Chapel Hill and the North Carolina State Library in Raleigh are nearly comprehensive in their collecting on the state level. Both collect local items too, but on a more limited basis. Of course, neither has all the municipal documents, the local church histories, the bird club newsletters, the programs from the dedications of new schools or parks, the maps showing proposed new developments or zoning regulations, or the local

Alice R. Cotten is Assistant Curator of the North Carolina Collection, Wilson Library, University of North Carolina at Chapel Hill. She also serves as Book Review Editor of North Carolina Libraries. newspapers. No one library can collect that extensively for every municipality in the state. Even if a library had the money, time, space, and staff to collect at this level, many of these ephemeral items are produced in limited quantities for a specific event, and the supply is quickly exhausted.

The greatest need today in the field of collecting North Caroliniana is for the acquisition and preservation of local information. Who is keeping local government documents-council minutes, annual reports, budgets, thoroughfare plans, ordinances and charters, proposals for waste dumps, and zoning regulations? Some public libraries are, and are doing the job well. One success story is that of the High Point Public Library, which a few years ago began a municipal documents collection and an index to the local newspaper. Their director, Neal Austin, reports that it has been an "effective low-cost project." In 1980 and 1981, the Documents Section and the Public Libraries Section of NCLA adopted resolutions and guidelines encouraging public libraries to reach agreements with local governments to collect and provide access to municipal documents. Some libraries showed interest, but there has been little coordinated effort since then. This project is worthwhile and deserves renewed emphasis.

There is also a need to preserve local, smalltown newspapers. The Division of Archives and History in Raleigh administers an excellent program that identifies, films, and makes available for purchase all eighteenth and nineteenth century newspapers, but there is no coordinated effort to assure that twentieth century local papers are preserved anywhere. A week rarely passes that someone does not come to the North Carolina Collection in Chapel Hill to ask for an issue of a small paper. He shakes his head in disbelief as a staff member says that the collection does not have that paper. "But you get all North Carolina newspapers, don't you?" he asks. "After all, you are the North Carolina Collection." We explain that we get only a few newspapers, mostly major dailies on microfilm, and that he should 
check with a library in the area in which the paper is published. Some newspapers do keep backfiles, but these are often incomplete, unavailable to researchers, or deteriorating. The historians, sociologists, political scientists, and genealogists of the next century will have to work without one of the essential sources of their professions unless we as librarians collect, preserve, and make available local newspapers.

Clipping files, or vertical files, of selected articles from local papers can be valuable. The North Carolina Collection at Chapel Hill began its clipping file in the 1940 s. By the mid-1970s, the file was large, deteriorating, and in need of an overhaul. The collection hired a student to go through the clippings (over 100,000), divide them into subject and biography, make an authority file, and

\section{The first question is how to define "North Caroliniana."}

arrange them in chronological order within each subject or name. The librray's Photographic Services Section microfilmed the file and made paper prints from the film. The collection bound 164 volumes of biographical clippings and 190 volumes of subject clippings. The project took about three years and was expensive, but users are enthusiastic, and the bound volumes are used heavily. The collection anticipates adding volumes at ten or fifteen year intervals. While an undertaking of this magnitude is not possible for most libraries, a clipping file of local information may be possible and will be used extensively by enthusiastic researchers.

Actively seek and keep publications from local schools, churches, civic organizations, clubs, historical societies, businesses, banks, chambers of commerce, and other similar organizations. Who knows what future novelist, president, scientist, or anarchist may today be writing for your local school's literary magazine. Someone should be keeping yearbooks, church directories (church bulletins in some cases), reports of businesses, and local promotional materials. These will be invaluable for the study of a local community's change.

Among the most used items in the North Carolina Collection in Chapel Hill are programs, directories, and brochures from early twentieth century women's clubs. These materials show important developments in women's history and social history in our state and nation. But the collection doesn't have them all, particularly those from small towns and rural areas. Minority materials of all sorts are important. Seek them and keep them if they are produced locally. The history of a community is incomplete without a record of the existence of the local Ku Klux Klan, the gay rights activists, and the Sneetches with stars upon thars' to complement the record of the Kiwanis Club, the Scouts, and the churches.

\section{Ability to Predict}

One of the most valuable qualities of a librarian responsible for a state and local collection is the ability to predict what will be valuable to future scholars. William S. Powell, former curator of the North Carolina Collection in Chapel Hill, was outstanding in this respect. In the early $1960 \mathrm{~s}$ he began gathering the printed commentaries of a little-known but outspoken announcer from a Raleigh television station. These "viewpoint" editorials of Jesse Helms are now used extensively by the media, faculty and students of the university, and other researchers. Several years ago the collection, anticipating increasingly heavy use of these editorials, had them filmed for security, withdrew the originals, and made paper copies from the film. While all television or radio commentators will not go on to become senators, their editorials, if available, will reflect some of the concerns of the community for present and future scholars.

Another example of Professor Powell's farsighted collection development policy was his tenacious collecting of telephone books and city directories for many towns and cities. These are wonderful sources for many kinds of information. They can be used, with appropriate caution, to document who lived where at what time and what businesses operated in a given year. City directories provide additional information: occupation, name of spouse, whether a person rents or owns his house, who lives at each address, and who has each telephone number. Possibilities for use are numerous.
The greatest need today in the field of collecting North Caroliniana is for the acquisition and preservation of local information.

Libraries sometimes overlook the value of local maps. These maps show growth, change, and development and should be collected and pre- 
served permanently. In the late nineteenth century, the Sanborn Fire Insurance Company in New York began printing large colored maps showing streets and structures in towns all over the United States. Today these maps are valuable resources for people doing architectural surveys, restoring homes, writing local histories, and many other projects. Locally produced maps are especially valuable, for they often show backroads or structures that do not appear on commercial maps.

Photographs are also part of North Caroliniana. Scholars of the next decade, or the next century, will be grateful to those libraries that preserve likenesses of local buildings, events, and people. With restoration efforts at a peak, many landmarks are being renovated for new uses, but many more historic buildings and houses have been demolished. For many of these buildings, no pictures exist.

\section{Minority materials of all sorts are important.}

Information about local authors and collections of their works are important additions to any library. Small press publications, limited editions, privately printed or published works, articles in journals or magazines are often not collected at all. The North Carolina Collection at Chapel Hill collects the works of many authors, but some escape its attention until their work is unavailable. And the number of North Carolinians who write-and publish-is increasing, making it harder for one library to collect all authors. Some authors are willing, even happy, to donate copies of their works to their local library. In addition to acquiring the works of local authors, libraries can add newspaper articles about the author, book reviews, and dust jackets to supplement the actual writings. The "literary scrapbooks" at the North Carolina Collection in Chapel Hill provide researchers with a lot of information about Tar Heel authors and their writings, information that is hard to find through normal literary indexes.

As Marjorie Lindsey of the North Carolina State Library pointed out, most of these items are not books. Maps, photographs, pamphlets, leaflets, and broadsides all require special handling, preservation, space, and the staff to acquire and process them. This paper has recommended that libraries collect extensively on the local level, recognizing that libraries have limits on money, staff, time, and expertise.
Collecting North Caroliniana is a challenge, and no one library can do it all. Most public and academic libraries collect some local material. A few collect extensively. Most collect on a limited basis because of the restraints mentioned earlier. There appears to be a need for communication and coordination, a "network for North Caroliniana." But unless libraries assume responsibility for collecting and preserving local information, much of it will be lost, and a part of the literary and historical heritage of our state will be gone forever.

\section{Acknowledgement}

The author acknowledges with appreciation the suggestions of Marjorie W. Lindsey of the North Carolina State Library.

\section{References}

1. "North Carolina Collection at the University," North Carolina Library Bulletin 6:1 (December, 1924): 11-12.

2. Jane Williams and Rebecca Ballentine, "Expanding Local Information Services in North Carolina Public Libraries," Popular Government 47 (Fall, 1981): 7.

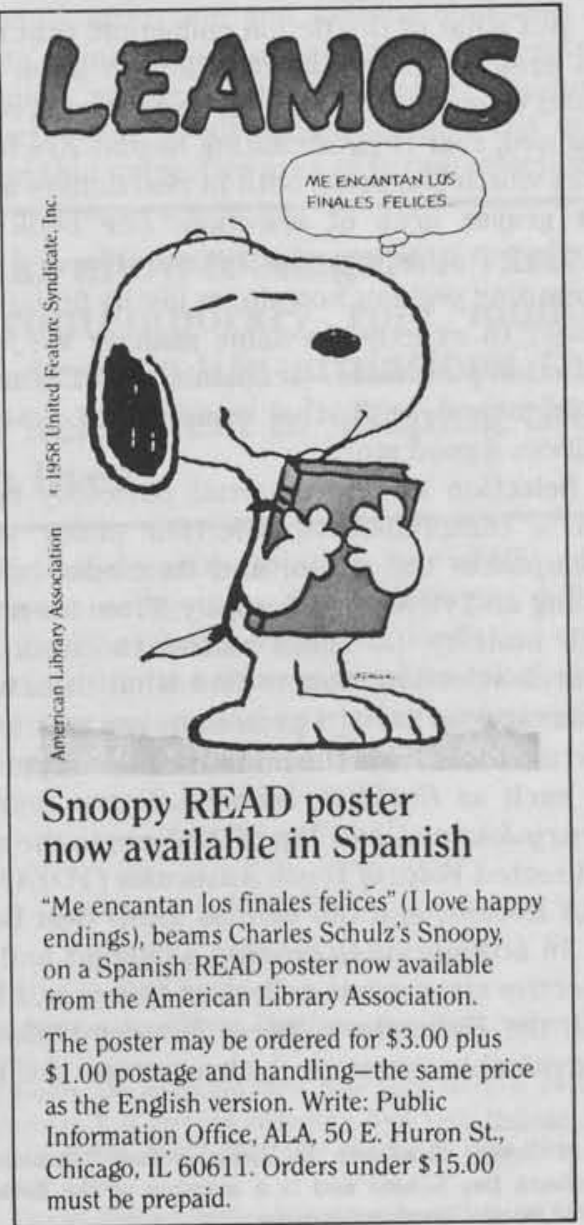




\title{
Developing Your Fiction Collection- Realistically Speaking
}

\author{
Frances Bryant Bradburn
}

As a school media coordinator attempting to develop an adequate, up-to-date collection for grades six through twelve, I usually have little trouble determining which nonfiction books to select and then justifying their purchase. The school's curriculum, student information needs, and my library budget tend to make these decisions moot points. Naturally, there will always be the weighing of one department's needs against another's, one grade or reading level over another, middle school materials as opposed to upper school materials. But the basic academic and information requirements are outlined for me, waiting only for money and appropriate materials before their purchase.

But what of the fiction collection, that nebulous area of the book collection so often overlooked when budgets tighten and censors, real or imagined, rear their inhibiting heads? Are fiction books worth the price, both in real dollars and in that grayer area of selection: one book over another? To this question I must answer a most resounding yes! But how do we justify fiction purchases? In exactly the same manner we justify nonfiction purchases-academic and information requirements-with the wonderfully aesthetic addition: a good story.

Selection of any material obviously begins with a comprehensive selection policy which encompasses the school and its media center's reading and viewing philosophy. From there it is, in all honesty, no small matter to continually research selection tools to find what titles really fit your special needs. I personally use a variety of selection tools, from the more traditional periodicals such as Booklist, School Library Journal, Library Journal, and Top of the News to the more YA-directed Voice of Youth Advocates (VOYA), the $A L A N$ Review, and the various YASD Best Books lists. In attempting to develop a current and retrospective sixth grade collection this year, I have found the Elementary School Library Collection an invaluable resource. I also peruse the local

Frances Bryant Bradburn is Upper School Librarian at Greensboro Day School and is a member of the Editorial Board of North Carolina Libraries. newspapers, New York Times, Christian Science Monitor, and various national magazines in my search for materials which serve the academic and developmental needs of sixth through twelfth graders and the faculty who teach them.

One of the most satisfactory means of justifying fiction purchases is by linking them to the curriculum. Take for example the obvious juxtaposition of history and historical fiction. Few history textbooks or class discussions can bring to life the women's suffrage movement as successfully as does Irene Hunt's book Claws of a Young Century. The quiet desperation and determination which ultimately gave birth to the Underground Railroad in Marcy Heidish's A Woman Called Moses and the graphic step back into time in Belinda Hurmance's book A Girl Called Boy force young people to relive the bonds of slavery if only in their minds.

History teachers often complain that students fail to see the relevance of the curriculum to their lives. Some of these complaints can be answered by units such as the World War II/Holocaust unit that the Middle School English and History teachers used last year. After reading as a class The Summer of My German Soldier by Bette Greene, students chose a book from a World War II/Holocaust bibliography of both fiction and nonfiction books. (See Appendix A.) As each student read his book, he selected one area of the war or the Holocaust in which he was especially interested. This specific topic was developed into a research unit from which a final research paper was the ultimate product.

Fiction integration is not limited only to the English or history curriculum. An equally successful unit was conceived with the upper school science department entitled "Nuclear War as an Environmental Issue." Titles such as O'Brian's $Z$ for Zachariah, Vonnegut's Cat's Cradle and Deadeye Dick, Frank's Alas, Babylon, Maruki's Hiroshima No Pika, and Golding's Lord of the Flies were combined with such nonfiction selections as Schell's The Fate of the Earth, Powers's Thinking about the Next War, Hersey's Hiroshima, and Ground Zero's Nuclear War: What's in It for You? 
Both fiction and nonfiction titles were used to stimulate students to think of the effects nuclear war has had and would have on the environment as we know it.

Ah, but those are the easy fiction purchases, you say. What about the other ones, especially those books on teenage life style-those "dirty" books-that someone is bound to complain about? You're right, of course. There are no easy answers; but there are suggestions.

No one is immune to questions about book choice. In this library, which serves grades six through twelve, I often have parents come to me with legitimate concerns about what they view as potential reading problems within our fiction collection. Most worry that their sixth or seventh grade child will read something written for an eleventh or twelfth grader, which he will not understand-or worse yet, which he will understand and then want to do something about!

\section{One of the most satisfactory means of justifying fiction pur- chases is by linking them to the curriculum.}

In talking with these parents, I very seriously discuss my philosophy of a young person's right to read-of everyone's right to read-and how it especially relates to choosing fiction books. It is important to me that all students be able to find books that help them make intelligent, knowledgeable decisions about how they wish to conduct their lives. Non-fiction materials are extremely useful in helping to formulate these decisions, but fiction books can offer a unique perspective. Fiction, particularly that genre we label "realistic fiction," places characters in a multitude of situations that young people potentially face. The key word here is potentially. Just because a student is reading about a particular issue or behavior does not necessarily mean that he or she is actively involved in it. But it does mean that he or she is at least thinking about the issue and consequently deserves the chance to make an informed choice. Children rarely read books voluntarily before they are ready for the subject matter contained therein. There are just too many things to do and read. Many times I have had students return a book with the comment "I didn't like this" or "I didn't understand this" or "I would rather read another book" or the insightfully honest "I'm not ready for this." But the student who is ready should have access to the book. Books allow teenagers a variety of contemporary role models and true-to-life situations that can help them in shaping their own lives. Adolescents certainly do not need, and do not necessarily desire, first-hand experience with various situations, problems, or emotions - but they do want to know about them. Books offer an ideal medium for vicariously facing a situation, watching how someone else handles it, and deciding whether or not that experience is worth incorporating into one's life pattern and, if so, when. As I assured one parent, "At least it gives them a few good lines to use."

right to expect some reading guidance from the librarian/media specialist for his child. This is why I have no guilt when I tell an immature sixth grader that I feel she will enjoy Harry Mazer's I Love You, Stupid! when she gets a little older, even though I have just booktalked the same book for ninth grade English classes. That is why I will fight to keep Aidan Chambers' Dance on My Grave and Nancy Garden's Annie on My Mind accessible on these library shelves even though I will steer most younger students in other directions. That is why I schedule afternoon and evening booktalks for parents' groups as well as using them for regularly scheduled student classes. Reading guidance lends credence to all book selections but especially in that subjective area of fiction selection.

\section{Books allow teenagers a variety of contemporary role models and true-to-life situations that can help them in shaping their own lives.}

Fiction deserves to take its rightful place among the competition for book-buying dollars. Yet it must be evaluated, like its nonfiction counterpart, within the framework of its relationship to the curriculum and to student information/ developmental needs.

Appendix A

World War II/Holocaust Bibliography

Beach, Edward. Run Silent, Run Deep. New York: Pocket Books, 1956.

Beaty, David, The White Sea Bird. New York: Morrow, 1979.

Bethancourt, T. E. Tune in Yesterday. New York: Holiday, 1978.

Brancato, Robin. Don't Sit Under the Apple Tree. New York: Knopf, 1975.

Davis, Daniel. Behind Barbed Wire. New York: Dutton, 1982. 
Dolan, Edward. Adolf Hïtler: A Study in Tyranny. New York: Dodd, Mead, 1981.

Ferry, Charles. Raspberry One. Boston: Houghton Mifflin, 1983.

Frank, Anne. Anne Frank's Tales from the Secret Annex. New York: Pocket Books, 1983.

Frank, Anne. Diary of a Young Girl. New York: Pocket Books, 1958.

Greene, Bette. Summer of My German Soldier. New York: Dial Press, 1973.

Haas, Gerta. These Do I Remember: Frayments of the Holocaust. New York: Cumberland, 1982.

Hersey, John. Hiroshima. New York: Knopf, 1946.

Hersh, Gizelle. Gizelle, Save the Children. New York: Everest House, 1980.

Hirschfeld, Bert. A Cloud Over Hiroshima. New York: Messner, 1967.

Koehn, Ilse. Mischling, Second Degree: My Childhood in Nazi Germany. New York: Greenwillow, 1977.

Koehn, Ilse. Tilla. New York: Greenwillow, 1981.

Korschunow, Irina. A Night in Distant Motion. New York: Godene, 1982

Magorian, Michelle, Good Night, Mr. Tom. New York: Harper \& Row, 1982.

Marrin, Albert. The Airman's War. New York: Atheneum, 1982

Maruki, Toshi. Hiroshima No Pika. Lothrop, Lee and Shepard, 1980.

McKay, Ernest. Undersea Terror: U-Boat Wolf-Packs in W. W. II. New York: Messner, 1982.

Reiss, Johann. The Upstairs Room. New York: Crowell, 1972.

Richter, Hans Peter. Friedrich. New York: Holt, Rinehart and Winston, 1970.

Richter, Hans Peter. I Was There. New York: Holt, Rinehart and Winston, 1972.

Siegal, Aranka. Upon the Head of the Goat. New York: VAL, 1983.

Takashima. A Child in Prison Camp. New York: Morrow, 1974.

Westall, Robert. Fathom Five. New York: Greenwillow Books, 1979.

Westall, Robert. The Machine Gunners. New York: Greenwillow Books, 1975

Nuclear War as an Environmental Issue Bibliography

Briggs, Raymond. When the Wind Blows. New York: Schocken Books, 1982

Frank, Pat. Alas, Babylon. New York: Lippincott, 1959.

Golding, William. Lord of the Flies. New York: Coward-McCain, 1962.

Groueff, Stepane. Manhattan Project. New York: Little Brown, 1967.

Ground Zero. Nuclear War: What's In It for You? New York: Pocket Books, 1982.

Harvard Nuclear Study Group. Living with Nuclear Weapons. New York: Bantam Books, 1983.

Hersey, John. Hiroshima. New York: Knopf, 1946.

Hilgartner, Stephen. Nukespeak, San Francisco: Sierra Club Books, 1982

Hirschfeld, Burt. A Cloud Over Hiroshima. New York: Messner, 1967.

Kunetka, James W. Oppenheimer: The Years of Risk. Englewood Cliffs, New Jersey: Prentice Hall, 1982.

Maruki, Toshi. Hiroshima No Pika. New York: Lothrop, Lee and Shepard, 1980.

O'Brien, Robert C, Z for Zachariah. New York: Atheneum, 1975.

Powers, Thomas. Thinking About the Next War. New York: Knopf, 1982.

Schell, Jonathan. The Fate of the Earth. New York: Knopf, 1982.

Vonnegut, Kurt. Cat's Cradle. New York: Dell, 1963.

Vonnegut, Kurt. Deadeye Dick. New York: Delacorte Press, 1982.

\section{RTSS Grant for the NCLA Biennial Conference}

The purposes of the grant are to encourage (1) membership in NCLA and RTSS, (2) attendance at NCLA Biennial Conferences, and (3) participation in RTSS activities.

The grant will be for $\$ 250.00$ to finance attendance at the next Biennial Conference of NCLA. Membership in NCLA and RTSS are required upon acceptance of the grant.

The grant will be awarded without regard to sex, age, or type of library.

\section{Criteria for Selection}

1. At least part of the applicant's current workmust involve an aspect of technical services: acquisitions, cataloging, classification, resources, collection development, preservation of library materials, or related activities.

2. The applicant must not have attended an NCLA Biennial Conference previously.

3 . The applicant must work in North Carolina.

4. The applicant must demonstrate financial need.

5. The completed application form must be neat and intelligible.

6. The applicant must secure work leave approval as appropriate.

\section{Conditions of Grant Acceptance}

1. The recipient must provide confirmation of acceptance in writing to the chairperson of the Resources and Technical Services Section.

2. The recipient must be a member of, or join, NCLA and RTSS.

3 . The recipient must attend the entire Biennial Conference and all RTSS functions and will assist with RTSS programs if requested by the Executive Committee.

4. The recipient must notify the chairperson of the section, and return the grant funds if the terms of the grant cannot be met.

The selection of the grant recipient will rest solely with the RTSS Executive Committee. In the absence of qualified applicants, no grant will be awarded.

For application forms, write to: Joline Ezzell, Head, Serials Department, Duke University Library, Durham, N.C. 27706. Deadline for applying: July 1, 1985. 


\title{
Collection Development in a Municipal Public Library
}

\author{
Robert C. Russell
}

Elbert Ivey Memorial Library is a municipal library for the city of Hickory. According to surveys of our borrower registration files, we serve a population of approximately fifty-five thousand people. Our citizens are well above the state average for both education and per capita income. The library has a collection of about 80,000 volumes, with an annual book circulation of about 180,000 . We are essentially a single-unit library system: we do not offer bookmobile service, and our one branch circulates fewer than 3,000 books a year. We have a staff of 15.5 FTEs, with three professional librarians (director, reference librarian, children's librarian). Our book budget is approximately $\$ 55,000$ a year.

This is not a "how we do it good" article, because we don't do it good, or at least we don't do it as well as we should; and I would guess that many, if not most, small and medium-sized libraries share this failure. Yet I am convinced that nothing we do is more important than collection development in determining the quality of library service that we are able to give to the public.

What follows is a discussion of the methods for collection development used in our library; some problems which result from the use of these procedures; and some changes we have made this year, which we hope will result in a better book collection and better procedures for maintaining this collection. I assume that most medium-sized and small public libraries use similar methods for collection development, encounter similar problems, and thus might find much of this information applicable to their situations.

I define collection development, in a public library, as the process of building a collection that meets the needs and interests of library patrons and that represents the best works available, for the layman, in all fields of knowledge. To the extent that these goals are in conflict (and because of budget limitations, they always will be), the balance will be determined by the person responsible for collection development in a particular library.

Robert C. Russell is Director of the Elbert Ivey Memorial Library, Hickory, and a member of the Editorial Board of North Carolina Libraries.
Collection development, as practiced in our library, can be divided into three major areas: current selection, retrospective selection, and collection evaluation. By collection evaluation, I mean the process of determining what materials we have in the various subject categories, as compared to what is available and also as compared to the demand for materials in each subject area.

I will now discuss the process of collection development in our library. For the sake of simplicity, I will confine my discussion to the area of adult non-fiction books.

At the beginning of the fiscal year, I divide our book budget among several areas: adult fiction, adult non-fiction, children's services, local history, and so forth. This gives us the total dollar amount available by area to purchase books during the year.

Most of our time and energy is devoted to selecting current titles. For selection tools, we use Library Journal, Booklist, Publishers Weekly, New York Times Book Review, state and local newspapers, and occasionally publishers' catalogs. We also rely heavily on patron requests in selecting new titles. We have a large number of active book clubs, whose members frequently request new titles well before they are reviewed. And finally, we of course look at the best seller lists and lists of books discussed on radio and television programs.

Four staff members participate in the book selection process: two veteran staff members, who have a good knowledge of the reading interests of book club members and other frequent users of the library; the reference librarian; and I. The selection sources are routed to all of these persons; they mark their recommendations and pass the journal on to the next person on the list. I am the last person to see each selection source and I make the final decision as to what will be purchased.

\section{Retrospective Selection}

The procedures for retrospective selection are much less precise. A few subject areas present no problems: we know that we must fre- 
quently replace or update materials on such subjects as resumes, armed forces and college entrance exams, and auto repair. Beyond this, the procedure becomes rather haphazard. The circulation staff may become aware of a need for materials in a given subject area because of comments by patrons or reserve requests. Staff members discover some obvious gaps while shelf-reading or shelving books. We go through discarded overdues (though not as thoroughly or as promptly as we should) to find titles that need to be replaced. When we run across subject bibliographies in Library Journal or other sources, we check these against our holdings and purchase what we think we need

None of these methods is really satisfactory. No staff member has the knowledge or training to identify every weak area in the collection by looking at the shelves. We do not have the available personnel to divide the collection among subject specialists. Many discarded books are out of print, and we often do not have (or at least do not take) the time to see if they need to be replaced with other titles on the same subject. And we certainly can't count on patrons to point out every gap in our collection. I suspect that the typical patron who does not find the materials he needs simply leaves the library without saying anything.

Last spring, we decided to make collection development one of our major goals for 1984-85. As we looked at the process described above, we became increasingly aware that we needed to do a great deal of work in the areas of collection evaluation and retrospective selection, as well as doing some fine-tuning of our methods for current selection.

No staff member has the knowledge or training to identify every weak area in the collection by looking at the shelves.

The first thing we did was try to determine why we were placing so little emphasis on collection evaluation and retrospective selection; why collection development had become, for the most part, current selection. We came up with the following reasons:

1. We had not developed any precise methods for collection evaluation. We did not have a clear picture of what was in our collection, of which areas were being used most heavily, and of which areas were weak.
2. We had no set of procedures, as we do for current selection, for doing retrospective selection.

3. Since we didn't have any organized method for doing retrospective selection, we had come to identify the book budget as funds allocated for purchasing books reviewed in current review sources. Thus, there was no money available for any significant retrospective selection project. It works something like this: I know that I have $\$ 24,000$ available to purchase adult non-fiction books. Without any conscious effort on my part, I establish in my mind what we can and cannot afford and I order about $\$ 2,000$ worth of books a month. I don't add figures or calculate discounts each time I read a selection tool and mark my choices. It just turns out that way, and I think that anyone with experience selecting books will find the same thing happening-what you have, you spend.

We then stated the following brief objectives for collection development:

1. Develop a method for determining what we have in our collection, as compared to what our patrons want and as compared to what standard bibliographies say we should have.

2. In both current and retrospective selection, emphasize the subject areas that are in greatest demand.

3. Make sure that we have a basic collection of recommended materials in all subject fields. We will, of course, use our own judgment in determining what is basic in any given subject area.

As stated earlier, goals two and three will often conflict, and we will again use our own judgment in deciding upon the proper balance between the two. (However, we did not see this as a problem, and thus far it has not been.)

\section{Collection Development Project}

With these problems and objectives in mind, we set to work on a collection development project. Our first step was to set aside $\$ 5,000$ for retrospective selection. This was money in the book budget but not available for selecting current titles from review sources. For the reasons stated above, I felt this was the only way we would have the funds available to do any significant amount of retrospective selection.

Our next task was to evaluate the collection. We needed to find out three things: what we had in our collection; what subject areas were in greatest demand by our patrons; and how what we had compared to what we felt we shouid have, using standard bibliographies. 
The first thing that became apparent was that our shelflist and card catalog did not give an accurate record of what we actually had in our collection, available for the use of our patrons. This was mainly due to the number of longoverdue books that had not been discarded. Our policy was to keep these cards for three years, and we had actually fallen a year or so behind that schedule. We discarded all of these long overdue books and pulled the cards from the catalog and shelflist. (We are now keeping cards for overdue books for one year before discarding the books and will probably reduce this time period to six months. I have done a couple of studies which indicate a return rate of less than 5 per cent after six months. To my mind, this rate of return does not justify keeping these cards in the catalog, deceiving both staff and patrons.)

We conducted a complete inventory of our collection two years before beginning this project. About one year after the initial inventory, we rechecked for all books which were missing in inventory and discarded those which were still missing. This brought us a step closer to an assurance that our catalog and shelflist provided an accurate record of our actual holdings.

Now it was time to gather some statistics. We chose the "quick and dirty" but fairly reliable method of dividing the collection by Dewey numbers and calculating for each area the percentage of our total collection and the percentage of total circulation. We had also kept statistics on discarded overdue and missing-in-inventory books and were able to use this information in our statistical study. Table $I$ is an example of the type of information this study gave us.

TABLE I

Library Holdings, Circulation, and Discards

\begin{tabular}{llll}
\hline $\begin{array}{l}\text { Classification } \\
\text { Range }\end{array}$ & $\begin{array}{l}\% \text { of } \\
\text { Collection }\end{array}$ & $\begin{array}{l}\% \text { of } \\
\text { Circulation }\end{array}$ & $\begin{array}{l}\% \text { of } \\
\text { Discards }\end{array}$ \\
\hline $170-179$ & .44 & .42 & .54 \\
$700-709$ & .83 & .23 & .49 \\
$950-959$ & .20 & .74 & .87 \\
\hline
\end{tabular}

We began with the assumption that, within a given classification range, the percentage of the collection, of circulation, and of discards should be about the same. If they were not, then we would need to examine these areas more closely and probably make some adjustments, buying more or fewer books in that subject area. For example, we would conclude that section 170-179 is about right, that we need to purchase more books in the 950-959 range, and that we have been purchasing too heavily in the 700-709 range. I must stress the fact that we used these statistics only as a starting point not as an absolute formula for allocating our book budget. However, we have now examined all of the areas which the table indicated needed to be examined and have found that, in most cases, the information can be used as a guide to purchasing more or less in those subject areas. (In some cases, we found that what was really needed was a more thorough weeding; in others, we decided, for various reasons, that we could justify over-emphasizing or under-emphasizing that subject area.) We have used this information to allocate the $\$ 5,000$ available for retrospective selection. I am also finding it helpful in choosing books from current selection tools.

Our third goal, as stated earlier, was to make sure that we had a basic collection of recommended materials in all subject areas. We decided that this was too much to tackle at one time, so we narrowed it down a bit. We decided to concentrate upon selected areas of the humanities and other subject fields in which there were likely to be easily identifiable "classics." We then used the appropriate sections of Public Library Catalog (most of the 100's, 200's, 800 's, and selected areas of the other schedules). These titles were checked against our catalog to determine basic titles which we do not own and need to purchase.

\section{Final Step}

The final step in the project was to select and order books; this phase is not yet completed. We are using Public Library Catalog to order the "basic collection" books and also for selecting titles in some of the subject areas in which we did not have sufficient materials, according to our survey of the collection and of circulation. It is immediately obvious that Public Library Catalog is not sufficient for selecting titles in many other subject areas. In these cases, we are using subject bibliographies, recent (last year or two) reviews in review periodicals, subject experts on the staff or in the community, and publishers' catalogs. (The Dover Press catalog is a good source for selecting books on chess, which was one of our weak areas.)

Surprisingly, we have not spent a great deal of time on this project. The circulation staff gathered the data on circulation by Dewey number while counting daily statistics. A Repay worker measured our shelflist and compiled statistics on the collection as broken down by Dewey number. Several staff members checked our 
catalog against Public Library Catalog, usually spending no more than thirty minutes a day on this project. This task took less than a month to complete. I evaluated all the data and compiled (and am still compiling) the lists of books to be ordered.

What time we did spend on the project was time well spent. Our circulation staff, from compiling the statistics and checking Public Library Catalog against our card catalog, has a better knowledge of our collection. I feel that my own knowledge of our collection and of the reading interests of our public is vastly improved. I have a much better idea of what we need, not only in doing retrospective selection, but in reading current reviews as well.

Along the way, we have developed a few methods and procedures that will be incorporated permanently into our collection development/book selection process. We will allocate funds each year for retrospective selection; we will pull all catalog cards for books within six months to a year after they become overdue; we will conduct circulation surveys at least every six months. These are just a few of the procedures that I feel will give us much better control over collection evaluation and retrospective selection.

The longer I work with our collection development project, the more convinced I become that it is essential that we continue to devote time and effort to the allocation of our materials budget. In every library, we carefully evaluate our personnel, shift job responsibilities, and reorganize departments in an effort to obtain maximum productivity from available personnel. We compare prices in supplies catalogs to stretch this part of our budget as far as possible. We use competitive bidding to get the best equipment at the lowest cost. We turn thermostats up or down to stretch our utilities budget.

Yet, all of these areas are peripheral to our most important function, that of providing materials to our users and making sure that we provide the best materials and materials on the subjects of highest interest to our patrons. I think it is essential that we devote at least the same level of time and effort to selecting books that we do to these other areas.

\section{Cleaver Symposium to be Held}

"The Cleaver Symposium: A Consideration of the Contributions of Vera and Bill Cleaver to Contemporary Children's Literature," sponsored by the School of Library Science and the Southern Historical Collection of the University of North Carolina at Chapel Hill, will be held May 23 through 25, 1985.

Speakers include Dr. Louis Rubin, writer, critic, and Distinguished Professor of English at UNC; John Rowell, author, book reviewer, and Professor Emeritus, Case Western Reserve; Sue Ellen Bridgers, author of children's books; and Pat Scales, library media specialist. Activities will also include a film and readers' theater presentation and a program given by the staff of the North Carolina Botanical Garden.

Mrs. Vera Cleaver will close the conference by responding to the symposium program and, with her editors, discussing the development of the Cleavers' novels.

For further information or registration materials, contact Marilyn Miller, School of Library Science, Manning Hall 026A, Chapel Hill, NC 27514

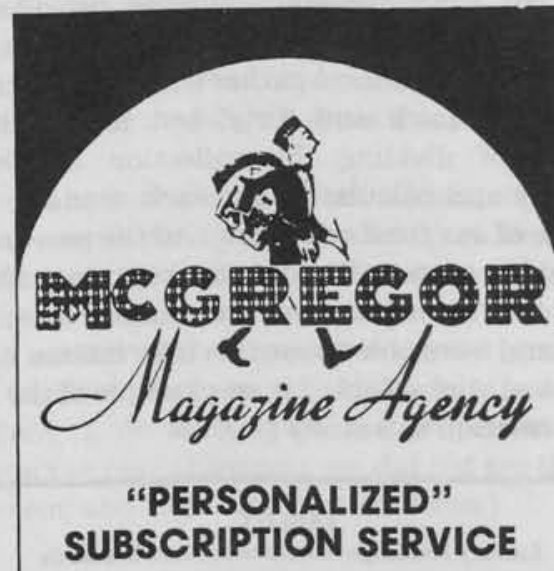

McGregor can simplify complex and time consuming problems of periodical procurement involving research, ordering, payments, renewals and record keeping. Prompt courteous service has been a tradition with McGregor since 1933.

- All domestic and foreign titles

- Title Research

- Prepaid Subscriptions

- Automatic Renewals

- Personal Service Representatives Call or write for catalog today $815 / 734-4183$

MCGREGOR MAGAZINE AGENCY Mount Morris, Illinois 61054 


\title{
Collection Development in a Public Library Branch
}

\author{
Patrice Gaffney Ebert
}

Collection: "An assembly of objects or specimens for the purposes of education, research, or interest." Development: "Gradual advance or growth through progressive changes." As these definitions from Webster's Third New International Dictionary imply, a library collection is a dynamic creature. Libraries have the power, as well as the responsibility, to shape their collections.

This article will attempt to explore the problems and opportunities in developing the collection of a large metropolitan branch. Some of the strategies, which can stretch even a fairly large budget, should have universal applications to the development of any branch library collection.

At first thought, one usually equates collection development with the selection of new titles to be purchased. While this is probably the greatest expenditure, many other factors enter into the overall strategy of collection development: replacement titles, added copies, mending and rebinding, gifts, weeding, and special collections. In the interplay of these factors, weeding dated and unattractive materials ranks as high as acquiring new and attractive materials. Equally important is the relation of the branch collection to other collections in the library system.

The Sharon Branch Library houses some 50,000 books and circulates 425,000 volumes annually. The fact that I manage a branch collection, even one which circulates more materials than the main library, takes some of the stress out of book selection. I do not have to make sure that I acquire every important title in any field; that is the central library's job. If our branch does not own a title requested by our patrons, we call the main library. The branch collection can be more tailored to the needs of our patrons. One of the most important lessons library school teaches is the admonishment to the professional: know your community. Branch libraries, as cogs in the machinery of a library system, allow the finetuning of a collection to the needs and wants of a neighborhood clientele.

\footnotetext{
Patrice Gaffney Ebert is Branch Head of the Sharon Branch Library of the Public Library of Charlotte and Mecklenburg County.
}

The central library in a system houses the research materials, costly reference titles, and comprehensive collections. The branches may then concentrate on recreational reading and books for homework topics. Let the main library get the costly, scholarly, and esoteric titles. The branches can borrow as needed.

Questions of literary merit versus popular demand are not so critical in a branch library. The selector must address this issue, to be sure, but patron requests must be considered in the neighborhood library. Some two hundred patrons, for example, queued up in a waiting list for Robert Ludlum's Aquitaine Progression at the Sharon Branch. One can always use rental plans to furnish multiple copies of massively popular titles. Weeding after demand subsides is no problem: simply return excess copies. Even if the library chooses to purchase multiple copies, cheaper book club editions are often available for mass best-sellers. (Book clubs are a marketing tool for the publishers who, as rumor has it, predetermine best-sellers with advertising budgets and marketing schemes.) Given the poor quality of many book bindings these days, there's a good chance that the extra copies, book club or not, will selfdestruct fairly quickly anyway.

\section{Let the main library get the costly, scholarly, and esoteric titles. The branches can borrow as needed.}

Given the popular tone of branch collections, the selection of new titles will always be the backbone of collection development. Branch patrons want a continually replenished supply of new books. I'm sure that every branch library has patrons who never venture past the new book shelf (or reserve shelf) into the stacks. They read book reviews and keep up with developments in the publishing world. Fiction-lots of new fictionmust be provided. 


\section{Genre Readers}

Then there are the genre readers. These patrons would not only love to have all the mystery, romance, science fiction, or westerns shelved together; they would never leave these areas were the library arranged this way. One way to save both time and money is to subscribe to the genre book clubs. I am not sure that the quality of this fiction is always top grade, but the patrons do not seem to mind. If they do object, they simply avoid the book club titles. In the best of all possible worlds, librarians would spend all their time on book selection and not have to worry about canned offerings. These genre book clubs, however, take some of the worry out by supplying a number of titles automatically each month.

New popular non-fiction also features prominently in selection needs. While each branch profile will differ because of community interests, some topics are of universal interest: crafts, cookbooks, how-to books, World War II, pop psychology, and so forth. Paying attention to topics in the news also pays off. In recent years, eating disorders such as anorexia nervosa have become "hot topics" for popular reading. On the other hand certain topics will be of local appeal. Sharon Branch, for example, offers a large collection of Judaica and Holocaust materials for our Jewish patrons.

\section{Given the popular tone of branch collections, the selec- tion of new titles will always be the backbone of collection de- velopment.}

Retrospective collection building is just as important in developing the collection as selecting new titles, but it requires more time, effort, and thought. Librarians know they are going to read all the reviews and get as many of those wonderful new books as their budget will allow. Taking the time to find gaps in your collection and then selecting titles to fill them is just not as much fun. It is easy to see gaps in the collection when following another selector. We are quick to notice deficiencies in areas where we have expertise or concerns. No matter how hard we try to be unbiased and complete, personal interests invariably influence book selection. As professionals, we must strive to overcome personal bias and provide balanced collections.
Patron requests for books and information that cannot be found in the collection identify areas that need development. It helps to keep a notebook at the desk for staff to jot down observations about titles and subjects in demand. Keeping records of materials borrowed from the central library and other branches also provides information about gaps in the collection. If a subject area consistently shows up, that collection needs some work.

Due to space and staff limitations, the reference and circulation functions are not separate in many branch libraries. This fact makes staff input all the more important. Everyone on the staff fields reference questions. These same staffers handle every book that crosses the desk. Their observations about patron needs and wants make significant contributions to collection development.

The Public Library of Charlotte and Mecklenburg County uses a formal scheme for ordering retrospective materials. Orders for certain Dewey classes and fiction are placed at specific times of the year. This plan facilitates the coordination of weeding and selecting new titles in subject areas. We keep a "collection development file" at Sharon Branch. Staff can note a needed title or subject at any time, then slip it into the proper class file. When the time to place orders for that subject area rolls around, comprehensive decisions about developing that collection are possible. Rather than building collections one title at a time by intuition and memory, this scheme offers the opportunity to evaluate a section as a whole.

Records of lost books also play a prominent role in retrospective collection building. While we never know all the materials which are lost, stolen, or strayed, we do know which books have been checked out but never returned. We review receipts for materials lost and paid, as well as long overdue files, and consider these titles for replacement.

Since the tax law no longer encourage publishers to warehouse copies of backlist titles, many books are going out of print more quickly. How distressing to find that the very titles one needs to replace are either out of print or available only in paperback! Paperbacks may be second best in some case, but at least they allow our patrons access to the books. Binding techniques which mount the paperback in a sturdy binding, such as Super-Flex or Permabound, or plastic jackets permanently applied to the paper binding, called "Cover-Ups," offer a longer circulation life. These pseudo-hardbacks stand up to as many circulations as the recent hardback offerings do. It makes sense to 
catalog these and shelve them in the stacks rather than in a browsing collection, since they are intended as permanent replacements.

\section{Homework Topics}

Homework topics feature prominently in retrospective collection building. As the largest branch with the largest reference collection outside of the main library, Sharon Branch attracts many students who live in the affluent southern part of the county. This is our greatest service to the older elementary through high school population; they are too busy with school and community activities to attend programs. They come to study and do research for their assignments. Their school libraries are closed after school hours. The public library must meet student needs for books and information. While we should not be expected to supply circulation needs, supplementary and research materials must be made available. This is perhaps the best way to serve our young adults and keep them as library patrons.

One way to supply enough copies for hot homework topics and mass assignments is to purchase multiple paperback copies. Identify titles by requesting reading lists from the schools. If the lists are not available, photocopy the lists students bring with them to the library. Even though the teachers may not assign the very same titles next year, be assured that those titles will cycle up as assignments again soon. The "summer reading lists" often contain standard YA titles and non-fiction titles anyway. All the more reason to purchase multiple copies. Certain subject areas inevitably show up as mass assignments every year: mythology, tree identification, science projects, Indians of North America, Shakespeare, and so on. Reach for the standard catalogs and select paperback titles for mass purchase.

\section{Retrospective collection build- ing is just as important in developing the collection as selecting new titles.}

Adult patrons have collection needs that can best be met with multiple paperbacks as well. Every branch librarian has ordered these materials over and over again: rẻsumé books, study guides for the Armed Forces placement tests, names for babies, and wedding etiquette. Since these books are subject to high loss rates, it makes sense to order paperbacks. Rather than investing in more expensive rebinding procedures, a strip of sturdy book tape on the spine will prolong the life of these paperbacks.

Weeding, the essential converse to acquiring materials, also develops the collection. It is a simple mathematical truth that branch libraries have only so much room. Unless the branch has serious hope of moving to larger quarters, one book must be weeded for every book acquired. In evaluating the collection, look for dated materials, superseded editions, ugly, ragged volumes, and materials that have not circulated in a given time period. Every library system should have a weeding policy with guidelines for weeding the various Dewey classes. An American Library Association publication, Evaluating and Weeding Collections in Small and Medium-Sized Public Libraries: The Crew Method (Chicago, 1980), offers valuable advice. Be ruthless. Systematic weeding not only frees space for more attractive and up-to-date titles; it also makes the branch library more appealing to patrons.

While the weeding process is continuous, I devote a good deal of time each summer to the books that have not seen any use. Pages read the shelves and pull any book that has not circulated in two years. These become weeding candidates. We then check the titles against the standard catalogs: Fiction Catalog, Public Library Catalog, Children's Catalog, and the Junior High School Library Catalog. We also consider availability at the main library and at other branches. Sharon Branch may not need a copy if the title is readily available elsewhere. Certain titles are retained because of literary merit or anticipated demand, but very few weeding candidates get back to the shelf.

Rebinding and mending worthy titles can be budget savers. Some libraries never rebind, figuring that patrons will want a clean, shiny, new copy. If the title is still in print and not very expensive, this theory works well. Sometimes, however, it is more cost-effective to rebind a used copy for one-fifth the cost of a new copy. At the time of this writing, it costs about $\$ 4.00$ to rebind a standard sized novel, yet a new copy may cost $\$ 20.00$. If the book self-destructed because of cheap binding practices, it makes little sense to purchase yet another copy from the publisher. Better to rebind and retain the original copy in a guaranteed binding. Paper jackets can be saved and then replaced with a clean, new plastic cover. Simple mending with glue and book tape can often prolong the life of a useful book. This is especially important for out-of-print titles or for 
books one just wants to keep around until replacements arrive.

Stringent standards should, of course, be applied to any bindery or mending candidates. Items to be rebound must have at least half-inch wide inner margins. The rebinding process trims away part of the pages at the spine. Consider whether illustrations will still be useful after trimming. Books mended with tape should never be sent to the bindery, as tape will gum up the binding machines. Never mend a book that you may want to rebind someday. Send it right to the bindery instead. No bindery or mending candidate should have dirty, stained, torn, or defaced pages. The paper should be of good quality, not yellow or brittle. These books, in general, should meet the same standards of quality as items considered for purchase. Non-fiction should be examined for accuracy and timeliness. If a newer edition is available, discard the superseded edition and purchase the newer. Fiction titles should either be listed in the Fiction Catalog or, if not, be of potential lasting interest in the collection because of the author or subject. Inspect mended books carefully after completion. They should still be clean and attractive. A bad mending job can ruin an otherwise useful book.

\section{Weeding, the essential converse to acquiring new materials, also develops the collection.}

Gifts can play a role in collection development, but some of the same caveats for rebinding and mending apply. Inspect gifts closely for condition, currency, quality, and need. Do watch for clean copies of out-of-print standard titles. Include only sterling candidates in the collection, remembering that even a "free" book costs the library its handling and processing time. Cash donations for new memorial books or magazine subscriptions are true budget savers.

Every branch library may develop special collections unique in the branch library system. While the central library holdings should be allinclusive, branches can strive to share resources among themselves. In Charlotte, for example, the South Branch collection includes the North Carolina General Statutes, while Sharon Branch houses the largest business reference collection in the branch system.

Every branch library contains a unique collection of materials. Careful attention to the details of collection development should result in a balanced, up-to-date, and complete collection especially designed for the needs of the branch patrons.

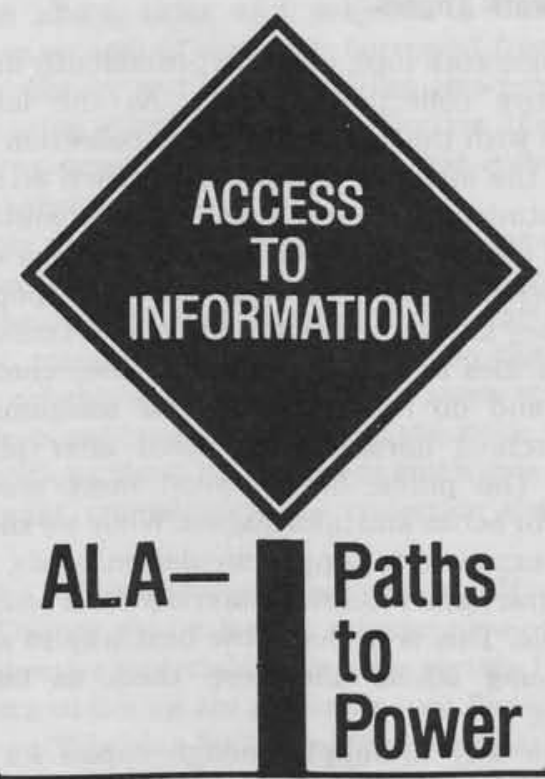

ALA - Paths to Power

Wou'll save: The special half price for New Personal Members is \$25; students $\$ 10$; renewing members \$50; non-salaried or retired librarians $\$ 15$; trustee and lay members $\$ 20$; foreign $\$ 30$ (effective 1984 calendar year).

Fou'll receive: American Libraries and its LFADS job listings; reduced rates at ALA conferences; discounts on AL.A monographs; eligibility to vote and hold office; an excellent group insurance plan; the backing of the most influential library association in the world.

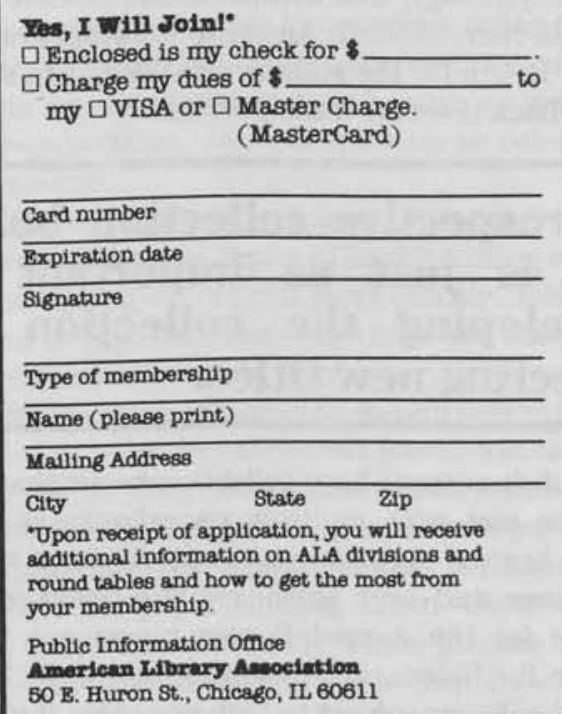




\title{
The Hatteras Library: A Small Unit in a Regional System
}

\author{
Anne D. Sanders
}

I first visited the Hatteras Library in December 1972. At that time the library was housed in an abandoned school building, was operated by volunteers, and was made up largely of gift books. Mrs. Lillie Peele, a Hatteras native and naturalborn librarian, spent most of her time managing the library, carefully selecting the few new books that the $\$ 500.00$ per year budget allowed, and maintaining records. Mrs. Peele and I immediately established a relationship full of mutual concerns for the library, not the least of which was to make the Hatteras Library a part of the East Albemarle Regional Library system. To make a long story short, that feat was accomplished in April 1977, at which time the library was moved to one section of the new Hatteras Community Building that now stands on the site of the old schoolhouse. Unfortunately, Lillie Peele did not live to see her dream come true, but I have made every possible effort since her death to make the Hatteras Library the kind of institution she so desired for the residents of the village.

A number of steps have been taken since 1977 to make the collection viable. First, the entire collection had to be screened. This was done under the supervision of Judith Israel, who was the Dare County Librarian at that time. After the initial sorting, all uncataloged books were classified by Elizabeth Hermann, a retired librarian and tireless volunteer. A card catalog was set up, and the library began to take shape. The major problem at that time was the scarcity of new books. The regional book selection policy stated that materials purchased for Hatteras would have to come from Dare County Library's share of the book budget. The regional book budget was so small then that none of the libraries was receiving an adequate number of new books. Therefore, a serious attempt was made to keep a large circulating collection in Hatteras, drawn from the other libraries in the region. When we could spare the money, we added some professional tools for the Hatteras librarian, Yancey Foster, and sometimes took several staff

Anne D. Sanders is Director of the East Albemarle Regional Library. members for a day-long work session to help catch up on filing and typing.

Then in $1983 / 84$, with additional state aid, we were finally in a position to study the Hatteras collection with enthusiasm. One article proved to be especially useful to Yancey, Amy Frazer (the Dare County Librarian) and me. The article, entitled "A Bare Bones Nonfiction Collection for Small Vermont Public Libraries" and written by Marianne Cassell, Development and Adult Services Consultant, Department of Libraries, Montpelier, Vermont 05602 , appeared in The Unabashed Librarian, number 45,1982 . Using the article as a starting point, Amy checked the shelves while I consulted with Yancey and took copious notes. As we talked, Yancey was able to recall requests for materials which the library did not own. Amy handled practically every volume in the non-fiction collection as we worked, thereby assessing its use and condition. When we finished going through the bibliography, I had several pages of titles and subjects to be ordered. These I turned over to Alise Irvin, in charge of acquisitions for the region, who used the standard catalogs primarily for sources.

A particularly difficult area for us was the reference collection, which was scant. Because the entire library space is only 1,890 square feet, we had to be highly selective in our choices. In the area of literature, especially, I thought of times when even our largest library could not satisfy the demands of students; what then should I choose for Hatteras, which had virtually no material in the 800 s? A trip back to the headquarters library proved helpful at this point. With pad in hand, I scanned the reference collection and noted the materials that had been most useful to me in the past.

For the large number of tourists who visit the Outer Banks in the summer, I was especially anxious to have available historical materials, as well as additional materials related to the area. These included commercial and sport fishing, boat construction, small engine repair, marine life, marine science, and seashell identification. I see this area of the collection growing in the future, as well it 
should. I strongly believe that public libraries should reflect the interests and natural characteristics of the area in which they are located.

Again, I gave subject requests to Mrs. Irvin, who carefully chose the best of each subject she could find. Our ubiquitous enemy was, and continues to be, space or the lack of it. It is in the area of adult fiction that space really presents a problem.

Amy's thoughts on this were that the adult fiction collection should be maintained largely by circulating titles from the other three libraries in the region, thereby utilizing shelf space to its fullest advantage. One of the advantages of a regional library is that both money and shelf space are extended by our constantly moving and sharing single titles. For example, it has been a policy of this system since the beginning to buy only one copy of a mystery or western title (unless there is a great deal of promotion of a particular title) for the entire region. Mrs. Irvin spreads the ownership so that one library gets every third new mystery or western title. The justification for this is that even if we had unlimited funds and space, we could never satisfy the appetites of our avid mystery readers. Since many mysteries are read at one sitting, they are returned quickly, which means that they will move on to the next library in a short time.

\section{Public libraries should reflect the interests and natural char- acteristics of the area in which they are located.}

The second opinion that Amy had was that the permanent adult fiction collection did not need to include as many literary classics as the other three libraries, since interlibrary loan could take care of any requests in this area. The Hatteras Library is visited at least once a week by someone from the Dare County Library or region for the purpose of transferring books and other library materials and equipment. In addition, I encourage Yancey to use the telephone as often as needed, even though Hatteras calls are long distance to the other libraries. Because of the distance involved, library service is made more efficient by the use of the telephone for requests. We also use the postal service to its greatest advantage. The Dare County Library and Hatteras Library staff have become quite resourceful in finding ways to transport books and equipment: the trustee who lives in Frisco, the sheriff, the mail truck driver, and anyone who is going to or coming from Hatteras, is likely to end up with a box of books and notes for Yancey or Amy.

Having concurred with Amy's suggestions, I then agreed that Hatteras should have its own copy of highly popular new adult fiction titles. Space for these titles is not a factor, since oftentimes the physical life of a popular book is not long, and the problem takes care of itself.

The next area we have to consider is the juvenile collection. For this, I am going to rely heavily on the expertise of our newest regional staff member, Carol Veitch, who holds a Ph.D. in Library Science. Carol was associate professor in the Department of Library Science at East Carolina University before joining us as librarian of the Currituck County Library. She also has twelve years experience as a school librarian. Carol will serve a double role in the region as county librarian and co-ordinator of children's services. Because she has been with the region less than a year, I have purposely waited on the Hatteras project until she is fully acclimated to the area and her new position. She and I have discussed the situation, and I feel confident that she will make prudent decisions.

One thing that I learned quickly as a director was to utilize the skills and expertise of my staff. In the area of collection building, I found this particularly helpful for the Hatteras Library. Creativity and resourcefulness were essential in dealing with the small space with which we had to work.

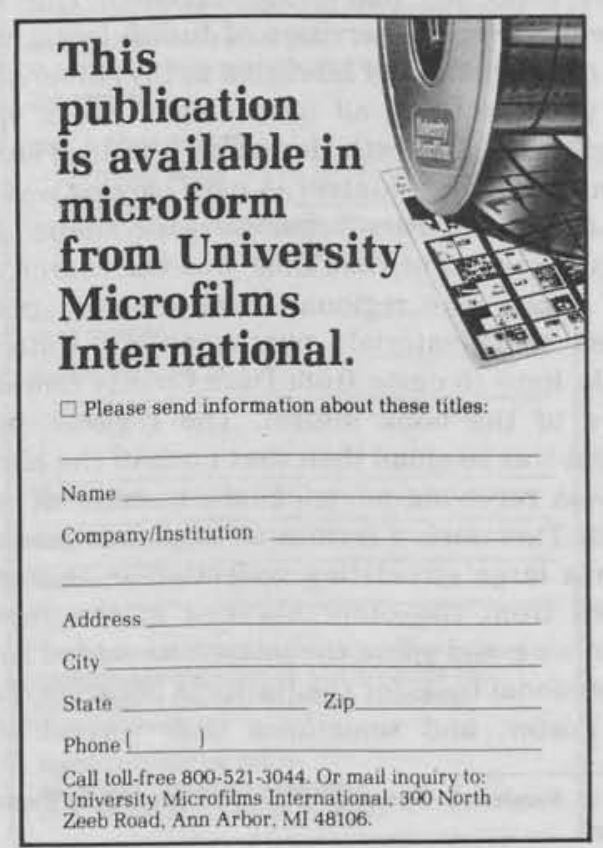




\title{
Merchandising the Collection from the Small Branch Perspective
}

\author{
Barbara Cashwell
}

Merchandising does move books! I learned about this concept at a Cumberland County Public Library staff training session in the spring of 1983. The program was informative, and displays were set up to reinforce the information presented. I was encouraged to select any of the materials used in the displays. These items included posters, wooden cubes, record covers, and boxes of various shapes and sizes.

Later that afternoon, I delivered the display materials I had chosen for my branch. My car looked like an early Christmas promotion with the brightly colored boxes and posters in the back seat. Once inside the library I was anxious to try my creativity with the displays. Time flew by as I spent the entire afternoon assembling the exhibits. Being creative did not seem like work.

I set up my first display on the floor in the juvenile section under the window. I used several boxes of different shapes and sizes, covering them with muted tones of different colored wallpaper. I put new fiction and popular paperbacks on and around this cubicle of boxes. This lay-out looked very appealing. But I was curious to see how long it would hold up under the three- to five-year-old inspection teams. Much to my surprise and delight, this display was never knocked down. I used this particular display for at least twelve months. The only thing that ever needed replacing was books!

My merchandising ideas overflowed into the juvenile section with another display. I used paperback dumps from a local book store on which I stapled a large cardboard poster of Judy Blume. After removing some of the dividing sections from the top, I displayed hardback Judy Blume books and paperbacks in the remaining slots. This display is currently being used and has often answered the inquiries as to the location of the Judy Blume books. Merchandising is truly effective in this area.

In the following weeks, I expanded on my ideas for the juvenile section with a small red bookcase placed at an eye-catching angle. Choose

Barbara Cashwell is Librarian at the Hope Mills Branch of the Cumberland County Public Library and Information Center.
Your Own Adventure, Return of the Jedi and Beverly Cleary paperbacks were displayed on the shelves. On top of the bookcase, I put new juvenile fiction and a large shallow basket, which held the Charlie Brown and Heathcliff cartoon soft copies. To complete the scene, a Raggedy Ann doll with legs crossed, reading a Beatrix Potter book, occupied the window sill nearby. Raggedy Ann has not had a chance to finish the book yet as it is so often borrowed by patrons.

The success of one particular display was aided by a friendly ghost. I constructed the ghost using a balloon for the head and a scrap piece of sheeting for the body. The ghost was suspended from the ceiling with fishing line. Black adhesive letters spelling "Ghost Stories" were stuck on the front of the ghost. Ghost stories, fiction and non-

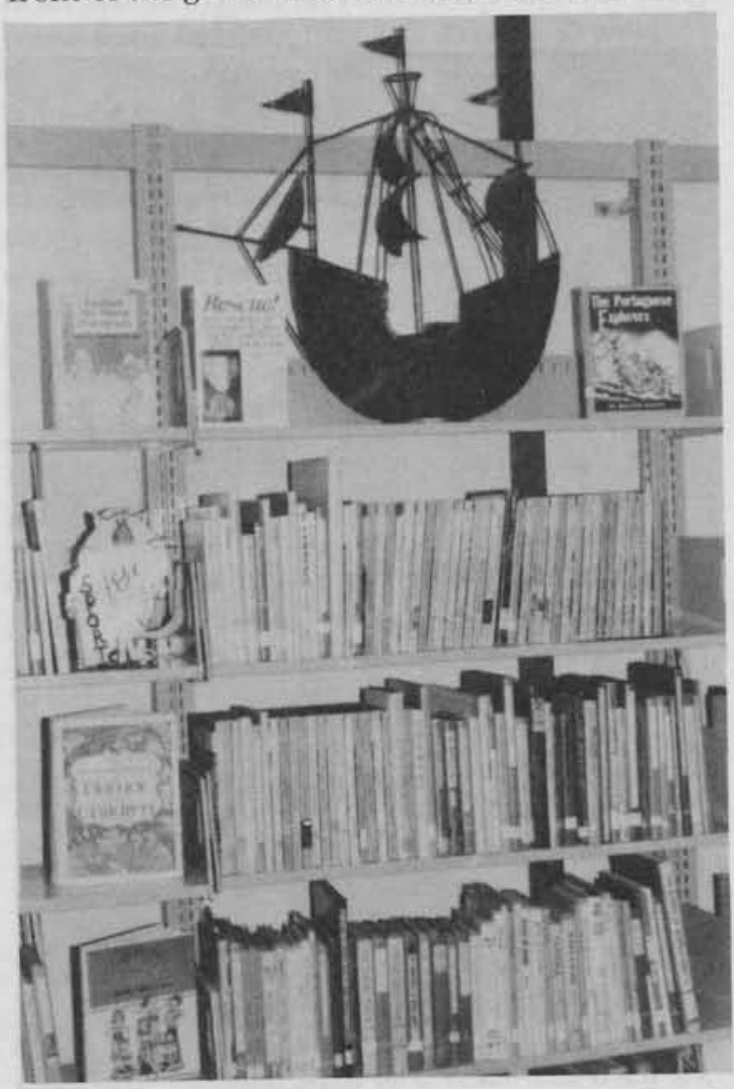

Sea adventure or pirate books are displayed on both sides of a metal ship in the $\mathrm{J} 900$ section. 
fiction, juvenile and adult, were placed on a display underneath the ghost. Books had to be borrowed from the main library and other branches to keep this display filled. Ghost tales are so popular that this could be used any time of the year.

A seasonal idea was introduced at Easter using baskets and colored eggs. In a small basket, there were small plastic eggs and a small stuffed bunny. In a larger basket, I used various colors of "Leggs" eggs. Books about spring, rabbits, and Easter, both fiction and non-fiction, were set up next to the baskets.

Encouraging interest through the use of "eyecatching" materials makes a very effective promotion. Displaying fiction and non-fiction books on the top shelves has also proved successful. What really completes the appeal is the addition of other imaginative objects. For instance, a metal ship is placed over the J 900 s. Sea adventure or pirate books are shown on both sides of the ship. Two puppet insects are also used along with a bright red plastic apple on some other shelving units. I have included an $8^{\prime \prime} \times 10^{\prime \prime}$ framed autumn scene on yet another shelf as well as a small framed clown picture to create a bright area. Last

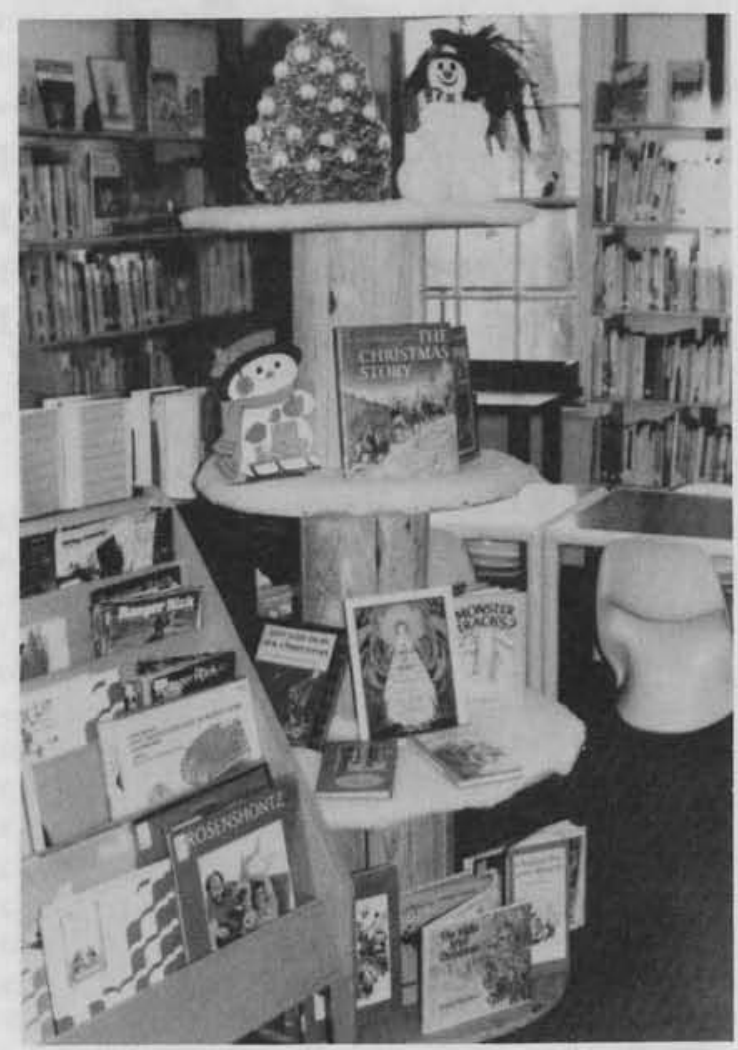

The wooden spools that wire comes on are stacked to hold a lot of books.
February, I did a black history display. A commemorative tray of Martin Luther King added just the right touch to this exhibit.

One of the best ideas I have incorporated uses the wooden spools that wire comes on. They were a contribution from an electrical supply company. I used various sizes in stacks of three and four spools. Although I chose not to paint mine, the idea of doing so would be a worthy extra. These spools hold a lot of books! On occasion I drape the spools with some type of fabric. I have beige velour on one of mine. Red satin or velvet would be nice during the months of December through February. Green material could be used March to May.

The eye-catching materials in merchandising are enhanced with easy-to-read signs. Such signs are regularly displayed on the "Best Seller" shelf, the "Classics" shelf, the "Mystery" location, the "Family Saga" exhibit and the ever-popular "Historical Romance" area.

Realizing the significance of the location of displays to the overall effect of merchandising, my branch relocated the paperbacks. I moved the rack closer to the front entrance in order to encourage the interest of the arriving patron. I included categories on romance, western and war adventure, horror, science fiction, and mystery. One of the most favored racks is a small wire one placed next to the charge-out machine. This rack contains the newest and most attractive paperback copies.

The ideas presented here are some of the most successful at our library. The effectiveness of these ideas is confirmed by patrons. More than one has made the comment "Your books seem to say, "Take Me!" I am convinced. Merchandising moves books.

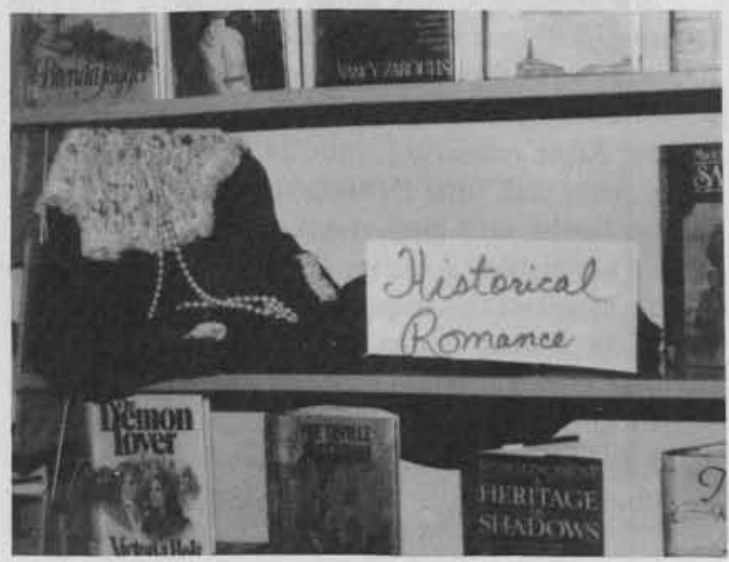

This eye-catching display highlights the historical romance section. 


\section{Librarians' Attitudes Toward Networking}

\section{Peggy Chapman}

Abstract. Networking, as an answer to library problems, is a concept that is receiving much attention. The attitudes toward networking of public librarians and school media specialists in Winston-Salem, North Carolina, were surveyed. While both groups agreed that there are many benefits to be derived from networking, more public librarians than media specialists expressed a willingness to participate in inter-library cooperation. Lack of clerical help was the overwhelming barrier identified by the media specialists.

In the world today, the information explosion is requiring immediate access to an abundance of resources; at the same time, libraries are facing uncertain funding. Some manner of cooperative effort seems to be inevitable if libraries are to bring their services efficiently and economically to those who need and want them. These cooperative efforts might require some major changes in the rules, regulations, and responsibilities that libraries have traditionally observed.

\section{Networking}

The system of obtaining resources from other agencies is called networking. In many circles of librarianship, this cooperation, or networking, is meeting with some resistance. If it is true that networking is effective at mobilizing total library resources, why is there opposition? The answers seem to lie in the attitudes librarians have toward networking. The question most frequently asked is whether such different kinds of libraries can truly share ideas, services and resources. One concern is that federal funding will not be continued and that networking will be resisted as librarians become more concerned about restricting the use of their collections to their patrons only. One problem in undertaking networking is getting people to work together productively.

If librarians' attitudes prevent them from wholeheartedly supporting the network concept, then this solution to the problems of increased

\footnotetext{
Peggy Chapman is Acting Coordinator of Media Services for the Winston-Salem/Forsyth County Schools.
}

library costs, increased demands for information, and greater cuts in library budgets will have little chance for success.

\section{Networking in Schools and Public Libraries}

Although there is a wealth of material in the literature on networks (e.g., the benefits of, barriers to, and history of the movement), there is very little descriptive research on how the attitudes of librarians affect their use of networks.

Illinois has been a leader among the states involved in networking. As early as 1965 the Library Systems Act was passed, providing for the establishment and development of a network of library systems. Much progress has been made in implementing this law. However, Robert Drescher, in an article written for Illinois Libraries in 1976, listed some barriers that still existed. Prominent among these barriers were several that directly relate to librarians' attitudes. ${ }^{1}$

Networking seems to work best when used among people who associate with each other in professional activities and who are friendly with each other. ${ }^{2}$ For cooperation to work, attitudes must be favorable, not only at the administrative level but also at the points of contact at all levels of activity.

In 1977 Johnson and Hines ${ }^{3}$ prepared a position paper for the Task Force on the Role of the School Library Program in Networking. In this paper, the authors stated that the literature showed the attitudes of librarians and some library users to be the major obstacle to participation in networks.

One bright note in the sometimes gloomy picture of uncooperative attitudes is found in a report by David W. Griffith. He enthusiastically enumerated all the forms of cooperation in which his library in Youngstown, Ohio, was involved for one year. He also emphasized the importance of attitude. ${ }^{4}$

Librarians raise many objections to networking when faced with the question of interlibrary cooperation. Many school librarians feel that they have little to contribute to a system of networking. Some personnel in larger libraries feel that, in 
joining a network, they will be overrun with requests and that their collections will be depleted. Although some of these fears are legitimate, there is reason to agree that "some observe that obstacles to resource sharing are not primarily technological but are human in nature. ${ }^{.5}$

\section{Hypothesis}

$\mathrm{H}_{\mathrm{O}}$ : There will be no significant difference in the attitudes of public librarians and of school media specialists toward networking.

\section{Methodology}

In order to assess whether the attitudes toward networking of public librarians are different from the attitudes of school librarians, a survey was conducted. The questionnaire was designed to ensure the anonymity of the librarian responding to the questions. In the upper right corner were the initials PL (for public librarian) or SL (for school librarian). These initials were necessary to identify the type of library from which the questionnaire was returned. There was no other mark of identification. A cover letter explaining the need for their opinions was sent with the questionnaire to the sixty-eight media specialists in the Winston-Salem/Forsyth County (North Carolina) schools and to the thirty-three professional librarians in the Forsyth County Public Library system. A stamped addressed envelope was enclosed.

Of the sixty-eight questionnaires sent to school media specialists, forty-eight were completed and returned. Table I illustrates the number of elementary, middle schools, junior high schools, and high schools represented by the completed questionnaires. The number of media specialists and the number of aides working in these media centers are also shown on the chart. It is evident that in most of the schools, the media center has a staff of only one person.

\begin{tabular}{|c|c|c|c|}
\hline \multicolumn{4}{|c|}{$\begin{array}{c}\text { TABLE I } \\
\text { Media Centers }\end{array}$} \\
\hline Level & Number & Media Specialists & Aides \\
\hline Elementary & 23 & 24 & 3.5 \\
\hline Middle School & 4 & 4 & 0 \\
\hline Junior High & 7 & 7 & 0 \\
\hline High School & 14 & 22 & 9.0 \\
\hline
\end{tabular}

Most of the schools in the Winston-Salem Forsyth County System have a large number of elementary and middle schools with each school serving relatively few patrons. The junior high and high schools are fewer in number, but each serves a greater number of students. (See Table II.)
TABLE II

Users Served

\begin{tabular}{lccc}
\hline Level & $300-599$ & $600-1000$ & Over 1000 \\
\hline Elementary & 14 & 7 & 2 \\
Middle School & 3 & 1 & 0 \\
Junior High & 4 & 3 & 0 \\
High School & 0 & 5 & 9 \\
\hline
\end{tabular}

It is apparent (Table III) that even in the smaller elementary schools the collections in each school are fairly substantial.

Of the thirty-three questionnaires sent to the professional librarians in the Forsyth County Public Library, twenty were completed and returned. Table IV illustrates the way in which the librarians, aides, users served, and collections are divided between the main library and the branch libraries.

\section{Summary of Survey Data}

Each librarian and media specialist was asked to put a check by selected types of materials on hand in his/her library. The questionnaire also instructed the librarians and media specialists to check the types of materials that they have requests or needs for and the types that they would be willing to lend to other facilities. The tabulations indicate that all the libraries and media centers contain most of these materials. Seventy-one per cent of the school libraries, but only 45 per cent of the public libraries have filmstrips; 73 per cent of school and 75 per cent of public libraries have records. All of the libraries contain fiction and non-fiction books. Seventyone per cent of the school and 60 per cent of the public libraries have AV equipment; 67 per cent of the school and 90 per cent of the public libraries have documents or pamphlets.

We asked to indicate how long a loan period they would consider satisfactory for sharing materials with other facilities, the public librarians were willing to use a longer time period. (See Table V.)

The librarians and media specialists were asked to list the benefits and drawbacks that they perceived as important in implementing interlibrary loans. The media specialists listed as benefits:

1. that materials not owned by individual media centers would become available to them (79 per cent),

2. that there could be a cost saving if there were less duplication in acquisitions (19 per cent),

3. that there would be an advantage in being able to work with other media specialists (4 per 
TABLE III

Collection Sizes - Books \& AV

\begin{tabular}{lcc} 
& More Than 7500 Items \\
\hline Level & Fewer Than 7500 Items & 21 \\
\hline Elementary & 2 & 3 \\
Middle School & 1 & 6 \\
Junior High & 1 & 13 \\
High School & 1 & \\
\hline
\end{tabular}

TABLE IV

Public Library

\begin{tabular}{lccccc}
\hline & & Fewer Thàn & Over & 7500 Items & 7500 Items \\
Librarians & Aides & 300 & 1000 & Or More & Or More \\
& & Users & Users & Books Only & Books \& AV \\
\hline
\end{tabular}

\begin{tabular}{|c|c|c|c|c|c|c|}
\hline Main Library & $\begin{array}{l}25 \\
10\end{array}$ & $\begin{array}{l}33.5 \\
20\end{array}$ & $\begin{array}{l}0 \\
1\end{array}$ & $\begin{array}{l}1 \\
5\end{array}$ & $\begin{array}{l}0 \\
2\end{array}$ & $\begin{array}{l}1 \\
4\end{array}$ \\
\hline
\end{tabular}

cent),

4. that interlibrary loans would be convenient for students (4 per cent),

5. that they believed the maximum use of materials would be a benefit of networking ( 4 per cent).

The public librarians considered the following items to be benefits of cooperation:

1. that more books would be available to their patrons ( 75 per cent),

2 . that there would be a cost saving in acquisitions with less duplication (40 per cent),

3 . that they would have more satisfied patrons (25 per cent),

4. that networking is a way to secure more current and varied materials (20 per cent),

5 . that interlibrary loans would make available to them out-of-print children's books (10 per cent).

There was general agreement between the two types of librarians that more materials would be available to them and to their patrons through networking. The public librarians foresaw the possibility of a much greater cost savings in acquisitions than the media specialists did.

Media specialists saw as drawbacks to networking:

1. lack of clerical help, thereby involving too much of their time and effort ( 75 per cent),

2. that their users would be deprived of materials (49 per cent),

3. that there would be greater damage to their materials, thereby causing them to have a shorter use time ( 25 per cent),

4. that they would have trouble getting materials on loan returned when they were due (19 per cent),

5. that many of their materials would be lost (17 per cent),

6. that a union catalog could not be kept current enough to be of use to them ( 6 per cent),

7. that they do not have enough materials to lend ( 4 per cent),

8. that the cost of networking would be prohibitive (4 per cent),

9. problems with the transportation of materials (4 per cent),

Drawbacks listed by the public librarians were as follows:

1. that their patrons would be deprived of materials that were on loan ( 35 per cent),

2. that the service would be too slow ( 25 per cent),

3. that cost would be a problem ( 25 per cent),

4. that too much time and effort would be involved in networking (20 per cent),

5. that materials would be kept beyond the due date ( 15 per cent),

6. that there would be "misuse" (not explained) of the network ( 15 per cent),

7. that smaller libraries would benefit more than large libraries (10 per cent),

8. that materials would be lost ( 10 per cent).

Most of the media specialists saw as the major drawback to networking their lack of clerical help. This problem was not a concern of the public librarians. Although both types of librarians felt that their users would be deprived of materials that would be on loan to other facilities,

TABLE V

Loan Periods

\begin{tabular}{lcccc} 
& Week & 2 Weeks & 3 Weeks & 1 Month \\
\hline Public Librarians & 0 & 5 & 2 & 12 \\
School Media Specialists & 7 & 29 & 0 & 5 \\
\hline
\end{tabular}


the media specialists saw this as a bigger problem than the public librarians did. Loss of and damage to materials were concerns to all the librarians, particularly to the media specialists. Ten per cent of the public librarians felt that smaller libraries would benefit more from networking than large libraries. Only one media specialist mentioned this as a problem of library cooperation.

Responses to the question, "Do you feel that you need to know more about networking at your level to perform your job?" differed to a statistically insignificant degree $\left(X^{2}=1.4, \mathrm{df}=1, \mathrm{P}>.05\right)$. of the forty-seven school media specialists answering this question, thirty-two said "yes." Ten public librarians answered in the affirmative, while nine felt that they could engage in networking with the knowledge that they currently possess.

When asked if they felt that having access to materials from other media centers and libraries would outweigh any inconvenience and extra work involved in lending their materials, nineteen out of the twenty public librarians answered that they did. The school media specialists felt different to a significant degree. Of the forty-one media specialists answering this question, only seventeen replied in the affirmative $\left(\chi^{2}=15.94, \mathrm{df}=1\right.$, $\mathrm{P}<.01$ ).

The public librarians and the school media specialists all thought that lending their materials would deprive their users of some services. However, thirty-six out of forty-six media specialists and seventeen out of nineteen public librarians felt that this inconvenience would be relatively small. Although there was a difference, it was not significant. In referring to Tables 3 and 4 , it is apparent that most of the school media centers and the public libraries have substantial collections. Possibly for this reason, both types of librarians felt that they did have enough materials to lend to other facilities. No significant difference between perceptions of media specialists and public librarians occurred on this question $\left(\chi^{2}=\right.$ $3.42, \mathrm{df}=1, \mathrm{P}>.05)$.

When the data were arranged by size of collection (i.e., placing both school and public libraries that own fewer than seventy-five hundred items in one group and libraries owning more than seventy-five hundred items in another group), there was no significant difference in attitudes toward becoming involved in networking.

When questioned about their opinions on the number of loan transactions per month that they would consider satisfactory, the school media specialists overwhelmingly chose the category 0 30 . This choice was the lowest number given in the multiple choice question. The public librarians' answers were evenly divided among the available categories: $0-30 ; 30-50$; and 50 and up $\left(\chi^{2}=51.03, \mathrm{df}=2, \mathrm{P}<.01\right)$.

The consideration of whether the use of networks would add to the cost of operating a library revealed that public librarians and school media specialists differed in their beliefs that costs would increase $\left(\chi^{2}=3.90\right.$, df $\left.=1, P<.05\right)$. This difference was, however, barely significant.

Answers to the last question really summed up the attitudes of all the librarians: it asked if given a choice they would prefer to be involved in networking. Sixteen school media specialists said yes, thirty-two, no; while fifteen public librarians said yes, and four answerd no $\left(\chi^{2}=11.36, \mathrm{df}=1\right.$, $\mathrm{P}<.01)$. This difference is statistically significant and large enough to leave little doubt of the opinions of the librarians surveyed in this study.

\section{Conclusions}

There is a scarcity of literature pertaining to librarians' attitudes toward networking. One study ${ }^{8}$ found that public librarians are not as willing to participate in interlibrary loans as school media specialists. According to another paper, ${ }^{7}$ school librarians were not cooperative either. There seems to be a general consensus that most librarians profess to be interested in networking but would actually prefer not to become involved.

This study was surprising in revealing a great difference between attitudes of school media specialists and public librarians in Winston-Salem and Forsyth County.

The school media specialists believed that the benefits of obtaining materials from other facilities would not be great enough to justify the inconvenience imposed on their own users, who might also be deprived of materials. The opposite view was held by the public librarians. Although they agreed that there would be an inconvenience to users, they felt that the value of library cooperation would outweigh the disadvantages.

In looking for the reasons for the finding that media specialists responded with twice as many negative answers as positive ones, several underlying causes can be found. By referring to Table I, it is evident that many school media centers have practically no staff. In most cases, one person must serve the users indicated in Table II, meet all the classes in the school, serve the needs of the faculty, and process all materials. The WinstonSalem/Forsyth School System does not have central cataloging. Some days, perhaps on the day the questionnaire arrived, one more task might seem to be too much. 
The public librarians serve just as many users as the schools, if not more. Public libraries maintain a larger staff, however, even in branch libraries. Cataloging is done centrally, and books arrive ready to be shelved.

The benefits of networking that the school media specialists and the public librarians listed are strikingly similar. They agree that more and varied materials would be available to their patrons, that costs could probably be cut by reducing duplication in acquisitions, and that their users would be more satisfied with their service.

It is interesting to note that, in enumerating drawbacks to inter-library cooperation, school media specialists listed first their lack of clerical help. The public librarians' first concern was that their users would be deprived of materials while they were on loan. This concern was the second one listed by the school personnel.

There is clear evidence in this survey that, at least in Winston-Salem and Forsyth County, there is a significant difference in the attitudes of public librarians and school media specialists toward networking. The null hypothesis was rejected.

Although the concerns of the school media specialists are justified by their lack of help, a solution to increased costs and lower budgets must be found. Participation in a network will do much to meet student learning needs as well as the resource needs of teachers and the general public. Networks should not be a substitute for effective local media service but should be an expansion of school and public library programs.

According to a plan for library cooperation in Pennsylvania, ${ }^{8}$ collective action works best among people who come in contact with each other in professional organizations and who are friendly with each other. Perhaps opportunities for school media specialists and public librarians to visit each other's libraries would be a good way for them to become acquainted with each other. Actual networking activities could begin on a small scale and grow as the participating libraries become more willing to share their resources.

Workshops or training sessions for the members who would be involved would be useful for working on and solving common problems and fears. At these workshops a handbook of policies, services, and key people could be compiled. In order for communications among libraries to be satisfactory, the time involved in making provisions for sharing materials must be kept to a minimum. By working on policies to deal with problems of this type before networking network- ing is begun, many unsatisfactory situations can be avoided.

The purpose of activities designed to involve different types of librarians in some form of cooperation is, one hopes, to start a change in their attitudes. If attitudes are indeed the major obstacle to networking, a change is needed before any form of networking can be successful. School and public librarians both "face enormous challenges and both will have to change, fundamentally, their attitudes and understandings about each other's programs, about learning and teaching, about services for people, and about information management. ${ }^{n g}$

There is no way to prove conclusively that attitudes direct our choices and our behavior, but there is strong evidence that this is true. Trian$\mathrm{dis}^{10}$ states that attitude is a contributing cause to behavior. "Scientists have felt the need for a concept 'attitude' for this purpose."11 Certainly the connection between attitudes and behavior is a very strong one. The traditional concept has been that the direction of this connection runs from attitude to behavior. There is reason to believe that this connection also runs in the opposite direction, i.e., that behavior sometimes influences the attitude. ${ }^{12}$

\section{References}

1. Robert Drescher, "School Library Cooperation in the Illinois Library and Information Network (ILLINET)," Illinois Librar ies 58 (September 1976): 548-551.

2. C.T. Meadow, A Plan For Library Cooperation in Pennsyl. vania, (Philadelphia: Drexel University, 1976) (ERIC Document Reproduction Service No. ED 136 757).

3. Mary Frances Johnson and Theodore C. Hines, "School Media Programs and Networking: A Position Paper." Greensboro, N.C. University of North Carolina at Greensboro, 1977. (ERIC Document Reproduction Service No. ED 175442 ).

4. David W. Griffith, "Cooperation: What's In a Name?" The Unabashed Librarian \#29 (1978): 32 .

5. David M. Moore, "Library Networks-A Technological System Whose Time Has Come," Journal of Educational Technology Systems 8 (1979-80): 147-53.

6. Esther R. Dyer, "Cooperation in Library Services to Children: A Fifteen Year Forecast of Alternatives Using the Delphi Technique," (Doctoral Dissertation, Columbia University, 1976). Dissertation Abstracts International 39 (1976): 1904A-1905A.

7. Esther B. Woolls, "Cooperative Library Service to Children in Public Libraries and Public School Systems in Selected Communities in Indiana." (Ph.D. Dissertation, Indiana University, 1973). 8. Meadow, op.cit.

9. D. Phillip Baker, "School and Public Library Programs and Information Dissemination," School Media Quarterly 5 (Winter 1977): 120.

10. H.C. Triandis, Attitude and Attitude Change (New York: John Wiley, 1969).

11. C.A. Kiesler, B.E. Collins, and N. Miller, Attitudes Change (New York: John Wiley, 1969): 5.

12. C.A. Insko, Theories of Attitude Change (Englewood Cliffs, N.J.: Prentice-Hall, 1967). 


\title{
New North Carolina Books
}

\author{
Alice R. Cotten, Compiler
}

Jill McCorkle. July 7th. Chapel Hill, N.C.: Algonquin Books, 1984. 387 pp. $\$ 17.95$.

Some librarians put their spare time to more interesting uses than others: Jill McCorkle wrote this spritely second novel during a stint as an acquisitions librarian in Melbourne, Florida.

July 7 th focuses on the lives of townspeople in Marshboro, North Carolina, on that particular day. The plot stems from an amalgam of blind chance, although the consequences have farreaching effects on the lives of the characters. Sam Swett, a disillusioned twenty-one-year-old on the run from New York City as well as from his southern parents, wakes from a bourbon-induced stupor to discover that he has witnessed a murder at the Quik Pik just off I-95. Harold Weeks is the second witness: he too suffers from a hangover and has been on the run from his wife, Juanita, ever since he caught her disporting herself in the room behind the Winn Dixie meat counter.

Other characters, whose variety springs naturally from southern stereotypes, brings the town to life; Juanita Weeks, a swinging electrologist who keeps herself fit for Harold's return by working out at the Nautilus; Harold's sister Kate and her husband, Ernie Stubbs, whose house in the Cape Fear Trace subdivision (formerly Piney Swamp) does not quite cancel out Ernie's upbringing on Injun Street; Corky Revels, a shy and lonely waitress at the Coffee Shop, who befriends the newest stranger in town, Sam; and Bob Bobbin, the policeman who decorates his apartment with red shag carpet and red and black velour wallpaper and who is only waiting to install matador lamps before he invites Corkey over for dinner.

McCorkle has a flair for believable characterizations, whether she deals with the elderly, such as Granner Weeks, whose goal is to reach another birthday while avoiding her son-in-law's efforts to install her in a highrise old folks' home, or with the poor, such as Fannie McNair, the black housekeeper for another family in Cape Fear Trace. Novelist Lee Smith comments, "Jill McCorkle has left the old stereotypes dead under the magnolias as she stakes out her own territory: the New South with its subdivisions and Winn Dixies and country music, lovesick electrologists and dopesmoking cheerleaders and swinging town cops, its tricky new racial and social balances. It's scary the way she invades her characters, writing so close to them that the books seem to happen inside your head."

July 7th captures the humor and pathos of life in a small town which also happens to be southern. Characterizations are recognizable stereotypes, but their actions and reactions ring true. McCorkle deftly balances Sam Swett's craving for detachment and perspective with the need for involvement in life, with all of its pettiness, joys, and sorrows.

McCorkle was raised in Lumberton, North Carolina, graduated from the University of North Carolina at Chapel Hill and received her M.A. from Hollins College. She now lives in Chapel Hill. She has been awarded the Jesse Rehder and Andrew James Purdy Prizes for fiction, and her short fiction has been published in Crescent Magazine and Seventeen. In an unusual step highlighting McCorkle's promise as a novelist, Algonquin Books simultaneously published both July 7 th and her first novel, The Cheer Leader. With these two novels, McCorkle, at age twenty-five, has her career well under way. lections.

July 7 th is recommended for most fiction col-

Margaretta Yarborough, Univeristy of North Carolina at Chapel Hill

John R. Finger. The Eastern Band of Cherokees, 1819-1900. Knoxville: The University of Tennessee Press, 1984. 253 pp. $\$ 24.95$ cloth, $\$ 12.50$, paper.

"Why another book on the Cherokees?" the author asks in his preface (p. xi). Surprisingly, there are no modern histories of the Eastern Band. Most of the accounts chronicle the early period of the tribe and the events that led up to its 1838 removal. Thereafter, scholarly attention has focused upon the Cherokee Nation and those who moved westward to the Indian Territory. This volume attempts to provide a history of how those who remained in the East "endured a pre- 
carious and anomalous legal status" and how these people were "somehow able to retain their identity as Cherokees throughout their travail" (p. $\mathrm{xi})$. A second volume is planned to cover the twentieth century.

Finger begins with a brief account of the origins of the Cherokees and, in particular, the origins of those who successfully resisted removal to the West. He demonstrates that these were the more conservative and less acculturated Indians who lived outside the Cherokee Nation in Western North Carolina. The author deals with the Tsali legend and convincingly argues that the Qualla Cherokees were not fugitives who avoided removal through the martyrdom of Tsali but traditionalists who were citizens of the United States under an 1819 treaty.

The following chapters chronicle the Eastern Band's constant struggle to ensure their right of permanent residency. The Cherokees wanted land and the legal status of citizens in order to preserve their traditional ways. But, to persuade state and federal governments that they deserved citizenship, they found it necessary to emphasize their acculturation and progress. For most of the nineteenth century the tribe was troubled by the tension between tradition and progress, a tension reflected in growing tribal factionalism, a tension resolved by Cherokees accommodating their ways to white expectations and adapting white institutions to their needs.

Throughout, attention is devoted to the role of William Holland Thomas, a white merchant who was adopted into the tribe and who for forty years served as their legal counsel, lobbyist, and tribal leader. Because Indians were disabled from owning land by an 1835 North Carolina law, Thomas spent much of his life acquiring property in western North Carolina for an Indian homeland. The author has clarified some of the confusions of Thomas's land dealings, the various suits and frauds involving the Eastern Band, and other threats to the Cherokee's land possession.

By 1900 the Eastern Band had been recognized by the federal government and had established its own tribal government. It had survived the devastation of civil war and epidemic. And it had resisted incursions onto its land and into its cultural heritage. The land and its resources, however, now accessible to the railroad, were attracting the attention of both lumbermen and conservationists. The Indians were taking tentative steps toward modernity while retaining the core of their traditions.

Finger does an admirable job of using archival and Bureau of Indian Affairs records to untangle the confused relations of the Cherokees with the federal and state governments. He also ably explicates the complicated affairs of William Holland Thomas. If he is less convincing in his cultural arguments, it may be because his sources, as he himself points out, are documents produced mostly by whites. But Finger has produced a readable volume that is likely to become the standard work on the subject. With an index and extensive bibliography, it is suitable for both informed laypersons and scholars. It should be acquired by most public and academic libraries.

Eric J. Olson, Appalachian State University

Tony P.Wrenn. Wilmington, North Carolina: An Architectural And Historical Portrait. Photographs by William Edmund Barrett. Charlottesville, Virginia: Published for the Junior League of Wilmington, NC, by the University Press of Virginia, 1984. 341 pp. $\$ 27.50$.

Although this book is primarily an architectural history of Wilmington's historic district and the surrounding area, Tony Wrenn does more than simply describe buildings and monuments. $\mathrm{He}$ also includes details of local history that relate to the structures. Consequently, Wrenn's audience includes those readers interested in local as well as architectural history. The book is very useful as a reference source and as a guidebook to take on a walking tour of the city. Since it has lots of photographs, many people especially interested in Wilmington will find this volume attractive as a coffee table book.

Wrenn begins with a short history of Wilmington, then describes the architecturally significant buildings of the downtown area. His spatial arrangement is street-by-street, beginning at the Cape Fear River and moving eastward to Ninth Street, then from Red Cross Street on the north to Surry Street on the south. This section is followed by the "Street Car Suburbs," an area of mansions and working class dwellings developed during the first two decades of the twentieth century. The final section describes nineteenth century cemeteries and early twentieth century parks.

Wrenn includes only structures standing at the completion of his study. When several buildings of a particular architectural style are extant, Wrenn chose a representative sample. Wilmington's black history is included in the study. For example, Wrenn's discussion of Pine Forest Cemetery, founded as a black burial ground, is especially interesting for its information about the 
people buried there. Nevertheless, the space devoted to black architectural history is less than that devoted to white architectural history because fewer structures unique to black history are still standing. Indeed, Wrenn makes no claim to being comprehensive; in fact, he urges others to continue this project of documenting Wilmington's architectural history.

Preceding the discussion of buildings is a general introduction to each street, and then each block, that typically describes the zoning of the area, the significant paving materials, the landscaping, and any extant street furniture. For each building or monument entry, Wrenn gives its name, construction date, architect, and builder. He then describes the architectural features of the structure and gives information pertaining to its original owner. Whenever appropriate, Wrenn mentions other notable owners or occupants of the building. He also records changes in the function of the building and business ownership and name changes. In these entries, Wrenn often quotes newspapers or other sources that give details of a particular building's history. Public buildings, such as churches or government structures, are given the lengthiest treatment, usually two to three pages. Residential buildings are each covered in less than a page. Over 180 black and white photographs and eight color plates accompany the text, thus providing illustrations for about half the entries. In the section on cemeteries and parks, Wrenn tells how each area was established and mentions markers significant either as art forms or for the people buried beneath them. Several of the gravestones mentioned are illustrated by photographs. The book concludes with two appendixes, one listing buildings in the National Register of Historic Places, the other listing early paving materials. There are also a note on sources and an index.

This volume is the result of dedicated research by several people. When he began the project in 1973, Wrenn was associated with the North Carolina Division of Archives and History, but he is now archivist at the American Institute of Architects in Washington, D.C. The Junior League of Wilmington sponsored this project, and members of the organization assisted with the building survey and searched deed books, newspapers, and other primary sources. Also working with Wrenn were several well-respected local historians associated with the Lower Cape Fear Historical Society.

The photographer, William Edmund Barrett, is a free lance architectural photographer in Centreville, Virginia. His photographs are excellent.
Each shot is taken from the angle best suited to show the details of the structure being discussed. They show imagination and skill.

On the endpapers of the volume are maps of the area, each with a key to the structures discussed. The typeface is large and clear. The paper and binding are of high quality, and the book will lie flat when opened. It is a durable and attractive volume that will be of most interest to those public and academic libraries whose clientele are interested in North Carolina history or architectural history.

Sue C. Hiatt, University of North Carolina at Wilmington

Robert J. Cain, ed. Colonial Records of North Carolina: Records of The Executive Council, 1664-1734. Raleigh: Division of Archives and History, 1984.763 pp. $\$ 25.00+\$ 1.50$ postage.

This is the seventh volume in the new series of colonial records. The first contains the charters and constitutions of the colony between 1578 and 1698 while the next five consist of the Higher Court records from 1670 to 1730 . Each of them, carefully and accurately edited and indexed, has made much new information about North Carolina available to historians and genealogists. In addition, the casual reader will spot interesting facts in all of them about such topics as clothing, debts, family relationships, household furnishings, Indians, jury service, land, Negroes, occupations, robbery, skins and furs, towns and trade, tools and equipment, wages, weapons, weights and measures, and a great deal more.

During the period covered by the latest volume, great changes took place in North Carolina. From the earliest settlement and creation of government well into the royal period, the executive council played a significant role; initially it was both advisory to the governor and legislative as a part of a unicameral assembly. Afterwards, however, it came to be regarded as an upper house. Members of the council also were often deputies of the Lords Proprietors and as such had a special role, yet when vacancies occurred the governor often filled them. Government in North Carolina, in other words, followed few rules. It developed and grew to meet local needs; directives from London were ignored with impunity.

In addition to dealing with the developing government, the volume also covers the period of the Tuscarora Indian War and the years when piracy flourished. Quakers were numerous and had political aspirations; attempts were being made at the same time to establish the Anglican 
Church, and these two opposing religious groups were the cause of considerable dispute. The council also had occasion to consider and act upon the matter of new settlements such as those on the Neuse and Cape Fear Rivers.

The forty-five-page introduction to this volume is a splendid, close look at the history of the colony during a limited period of time. It sets the stage for the documents that follow, but it also relates them to other contemporary events. The editor has included new facts and interpretations that will surely find a place in general histories of the state in the future. The splendid, detailed index opens up a large variety of subjects and makes the volume a delight to the trivia buff as well as to the historian, the general reader, and the reference librarian. All will find facts and fancy to please.

William S. Povell, University of North Carolina at Chapel Hill

Marguerite Schumann, ed. Grand Old Ladies: North Carolina Architecture During the Victorian Era. Introduction by Sterling Boyd. JoAnn Sieburg-Baker, head photographer. Charlotte: The East Woods Press, 1984. 128 pp. \$19.95.

Grand Old Ladies presents the first statewide, thematic approach to the architecture of North Carolina since The Early Architecture of North Carolina; A Pictorial History, by Frances Benjamin Johnston and Thomas Tileston Waterman, appeared in 1941 (and which has been long out of print). That volume was devoted solely to the study of the state's architecture of the antebellum period, so that Grand Old Ladies furnishes a much-needed pictorial survey of North Carolina's architectural heritage dating from the immediate post-Civil War period through the first decade of the twentieth century.

Fittingly, the North Carolina chapter of the Victorian Society of America sponsored the book's publication, with society member Marguerite Schumann serving as editor. Miss Schumann, Publications Officer at the University of North Carolina at Chapel Hill, is the author of Tar Heel Sights, A Guide to North Carolina's Heritage; The Living Land, An Outdoor Guide to North Carolina; walking guides to several North Carolina universities; and other historic and architectural works. The twenty-two page introduction, by Sterling Boyd, former head of programs at the North Carolina Museum of Art, is by no means a scholarly essay, but it gives the reader a concise interpretation of the state's architectural development during the Victorian era.
Of course, the greatest attraction of the book is the collection of photographs of the Victorian courthouses, churches, college buildings, stores, and predominantly, houses, the grand old ladies themselves with wrap-around skirts of gingerbread porches and peaked bonnets of turrets and towers with cast iron cresting and patterned roofs. The head photographer for the book, JoAnn Sieburg-Baker, is a free-lance architectural photographer with several awards to her credit. An excellent photographer, Ms. Sieburg-Baker provides a number of stunning pictures. Particularly notable are her depictions of the Daniel Branson Coltrane House in Concord; the Barracks in Tarboro; the interior of the Redmond-Shackleford House, also in Tarboro; and Eaton Place in Warrenton. In addition, the book features a number of photographs taken by the staff of the state Division of Archives and History. Scattered among the photographs are excerpts from the writings of North Carolina authors, with Doris Betts, Max Steele, and O. Henry among them, containing appropriate references to Victorian buildings, both real and fictional. The photographs represent buildings from one end of the state to the other, as well as the full range of Victorian styles from the simple board-and-batten St. Barnabas Episcopal Church in Snow Hill to the overblown extravaganza of Biltmore House in Asheville.

Grand Old Ladies has two major drawbacks for the reader. One is the annoying division between the text, which contains the information on the buildings, and the photographs, which have captions giving only the name and location of the building; the reader must continually flip from the pictures to the text looking for more information. The other drawback is the lack of color photography, always an expensive asset to any volume. The beautiful color dust jacket allows for great disappointment when the reader opens the book to pages of black-and-white photographs. The distinguishing feature of Victorian architecture was the overwhelming desire to pit building form against form, and texture of material against texture, with all of it highlighted by a wide range of colors. As excellent as the blackand-white illustrations are, the lack of color prevents the reader's access to an important dimension of the architecture.

Nevertheless, Grand Old Ladies does present a comprehensive pictorial survey of the state's Victorian architecture and as such will be of interest to libraries and readers in every county of the state, although the lack of footnotes and bibliography prevents its use as a reference tool. For those interested in historic preservation, neigh- 
borhood revitalization, and the economic and social development of North Carolina in the last half of the nineteenth century, Grand Old Ladies offers the best examples of the state's man-made heritage from an important and exuberant period of the state's history.

Marshall Bullock, University of North Carolina at Chapel Hill

Belinda Hurmence, ed. My Folks Don't Want Me to Talk about Slavery: Twenty-one Oral Histories of Former North Carolina Slaves. Winston-Salem, N.C.: John F. Blair, 1984. 103 pp. $\$ 14.95$ cloth, $\$ 5.95$ paper.

With experience as a fiction editor before becoming a librarian, Belinda Hurmence brought a critical eye to the perusal of young people's literature. What she did not see was enough good writing about the black experience for young blacks to read. So she began writing for them herself, first stories for Humpty Dumpty and Jack and Jill, then novels about black children (Tough Tiffany, A Girl Named Boy), and most recently, Tancy, for which she received the 1984 American Association of University Women Award for Juvenile Literature from the North Carolina chapter. With My Folks Don't Want Me to Talk about Slavery, Ms. Hurmence moves into editing oral history. The introduction sets forth her reasons for compiling it and describes the extent of her editing. It was her own reading of narratives collected in the 1930 s by the Federal Writers Project that revealed to her how vividly these statements by elderly former slaves conveyed a sense of life in bondage. Aware of the continuing need to deal with an issue so significant in American history, she determined to make these powerful words more accessible for young people. She chose to focus the collection on North Carolinians' accounts and only on those of men and women who were ten years old or older when freed. From 176 North Carolina interviews, she picked 21. She regularized dialect spellings, cut hearsay, and omitted unnecessary repetitions, but she retained grammatical structures indicative of the original speakers.

Her introduction also contains a careful reminder about influences on the content of these oral histories. For example, she points out that the memory of times long past may not be as thoroughly accurate as they seemed to the speaker, that looking back from the midst of the Depression could make earlier times appear happier in contrast, and that a black former slave might say what he thought a white interviewer wanted to hear. Young people, new to reading and thinking critically about oral history, are provided with the basic intellectual tools for discovering in it valuable evidence of human experience. Additionally, Ms. Hurmence presents a fresh viewpoint: these memories of slavery are also memories of the lives and work of America's black pioneers. Their condition of servitude cannot negate the contribution they made to building and sustaining the country's growth.

Familiar place names will enable many a North Carolina reader to envision these scenes of "slavery time" as set on neighboring terrain. As the narrators describe living in slavery, they repeat each other in the lament of many hard conditions, but variety of experience is equally apparent. Slave owners are often recalled with considerable affection, but the small kindnesses that earned such regard are disproportionate to the misery so widely inflicted by other masters and through Reconstruction hatred and its aftermath. W.L. Bost was surely not alone to observe, "I didn't know the Lord would let people live who were so cruel."

Many of these former slaves recall owners' methods of control; beatings were common but no more effective than the separation of slave families and the strict denial of education. Such patterns were maintained through 246 years of American history. Their debilitating effects on individuals and on efforts to establish new patterns when freedom was finally granted are strikingly evident in each account. These conditions meant that the struggle for freedom was supplanted by a struggle with freedom when even to name the cause was a risk. The book's title was taken from the words of Sarah Debro: "We's come a long way since them times. I's lived near about ninety years, and I's seen and heard much. My folks don't want me to talk about slavery, they's shamed niggers ever was slaves."

But Sarah did talk about it and so did Patsy Mitchener. She was owned by a Raleigh newspaperman. To her interviewer, she suggested that her master's record of the past, his paper, could be found in the museum, about which she added, "I reckons they keeps all way back yonder things in there just to remember by." Fortunately we also have her words to remember by. Belinda Hurmence has made them available to young people, black and white, who can find in them an important part of the history they share.

Tucker Respess, University of North Carolina at Chapel Hill 
Hubert A. Eaton, "Every Man Should Try." Wilmington, N.C.: Bonaparte Press, 1984. 360 pp. $\$ 17.95$ cloth, $\$ 9.95$ paper, plus $\$ 3.00$ for shipping and handling. (P.O. Box 517, Wilmington, NC 28401).

Wilmington, North Carolina, the home of the Wilmington Ten and the frequently analyzed race riots of 1898 , is also the home of Dr. Hubert Eaton, well known leader in the civil rights movement in North Carolina. In "Every Man Should Try," Dr. Eaton has told the story of his life, highlighting the long and involved lawsuits he initiated to end racial discrimination in New Hanover County.

Eaton describes himself in 1947 as a thirtyone-year-old successful doctor surrounded by a loving family and comfortable home complete with private tennis court. He was shocked to discover the use of two Bibles, one for whites and the other for "coloreds" in a New Hanover courtroom. "Segregated Bibles! I was stunned. It was like TIA-a little stroke. My eyes fogged, my ears hummed and a quiver ran down my spine. I almost gasped."

Shorly thereafter Dr. Eaton and a colleague, Dr. R.C. Roane, decided to investigate the schools in New Hanover County to determine if the county was adhering to the separate but equal laws as set down in the 1896 Plessy v. Ferguson Supreme Court ruling. With little cooperation from the New Hanover County School Board, a series of class action suits had to be initiated using Hubert Eaton, Jr., then seven years old, as plaintiff.

In 1954 when the Supreme Court overturned Plessy $v$. Ferguson in favor of ordering the desegregation of public schools, Dr. Eaton soon realized that New Hanover County would have to be prodded to comply with the new law. Despite numerous class action suits and vital support from the NAACP Legal Defense and Educational Fund, it was not until the 1971-72 school year that the New Hanover School Board complied with total integration. The New Hanover County public schools remained under court order stemming from Eaton's suits until 1983 and was the last school system in the state to ask for the court order to be lifted.

Other desegregation actions taken by Dr. Eaton deserve mention. He was associated with several lawsuits to end discrimination in the medical care provided in New Hanover County. In more peaceful efforts, he was successful in integrating the YMCA, the City Golf Course, the Wilmington Public Library, and Wilmington College (now UNC-W).
Of particular interest is his unique relationship with Althea Gibson. Dr. Eaton and a medical colleague undertook the education, coaching, and support of Ms. Gibson with the idea that she would break the color barrier in international tennis. She was the first black to win at Wimbledon, in 1957 and 1958.

Carefully saving the letters, papers, photographs, and newspaper clippings associated with his busy life, Dr. Eaton documents his memoirs well. Photographs taken in 1950 comparing New Hanover County's black and white schools are particularly moving. Appendixes reveal Eaton's interest in both the history and future of the black physician in North Carolina.

To say that "Every Man Should Try" is a significant contribution to the black history, contemporary history, and local history of North Carolina would be an understatement. It's easy readability also makes it a must for high school, public, and college libraries across the state.

Beverly Tetterton, New Hanover County Public Library

Jeffrey J. Crow and Flora J. Hatley, eds. Black Americans In North Carolina And The South. Chapel Hill: University of North Carolina Press, 1984. 200 pp. \$19.95.

Readers interested in North Carolina history will perhaps be familiar with The Southern Experience in the American Revolution and Writing North Carolina History. These volumes, both edited by Jeffrey J. Crow and Larry E. Tise, were published by the University of North Carolina Press in 1978 and 1979 respectively. Like these earlier volumes, Black Americans in North Carolina and the South consists of essays presented originally at a symposium sponsored by the North Carolina Division of Archives and History. The papers delivered at this more recent symposium, held in February 1981, have been edited by Jeffrey J. Crow, the division's historical publications administrator, and Flora J. Hatley, coordinator of the division's black history program.

Black Americans is a less substantial and less cohesive volume than the two published previously but is nevertheless a significant contribution to the state's historical literature. Its six essays include a historiographic survey, a methodological proposal, a demographic study of eighteenth-century North Carolina, and three essays relating to particular institutions or setttings. Raymond Gavins, who teaches Afro-American history at Duke University, reviews the literature 
of black history in North Carolina, interweaving comments on books, articles, and dissertations with information relating to the study of black history and the history of race relations in the state. This essay, with its twenty-three pages of notes, is a useful introduction to research on black North Carolinians up through 1981. In a much briefer essay Leland Ferguson, associate professor of anthropology at the University of South Carolina, calls for further archaeological study of black Americans, especially in the South. He offers examples of archaeological investigation and notes the kinds of information that can and cannot be obtained through such study. The third essay, "A Demographic Analysis of Colonial North Carolina with Special Emphasis upon the Slave and Black Population," discusses such topics as immigration and natural increase as sources of population growth, changes in population density, and the implications of sex ratios and sex imbalance ratios on familial patterns. Thoroughly documented tables present the extensive statistical data upon which the authors, Marvin L. Michael Kay and Lorin Lee Cary, professors of history at the University of Toledo, base their conclusions.

The three final essays relate to the period between 1860 and World War I. Linda M. Perkins, whose doctoral research at the University of Illinois dealt with black educational history, describes the experiences of northern black women who taught under the auspices of the American Missionary Association in the South during the $1860 \mathrm{~s}$. She focuses on their motivation for teaching and the discrimination they faced within the association. Howard N. Rabinowitz, associate professor of history at the University of New Mexico, compares race relations in southern cities, especially Raleigh, with conditions in northern cities between 1860 and 1900. His observations concerning Raleigh are similar to conclusions offered earlier in his book Race Relations in the Urban South. Todd L. Savitt, who teaches medical history at East Carolina University, traces the history of Leonard Medical School at Shaw University from its establishment in 1882 to its closing in 1918 because of inadequate funding. He relates the institution's history to developments in medicine and to the needs of the black community.

All six essays are well documented. Several make good use of tables to present data, and several benefit from illustrations, of which there are two dozen in all. The volume is indexed, but there appear to be no entries in the index for names, titles, or topics mentioned in the notes to the essays. The absence of such entries is unfortunate particularly with regard to Gavin's historiographic essay. While one might wonder whether most of the essays could just as well have been published as articles in various journals rather than as a collection of essays, still one can appreciate the contribution the volume makes to promoting the study of black history in North Carolina. Though Black Americans is suited primarily for students and scholars, it will be a useful addition to library collections serving adult readers interested in the history of blacks and race relations in North Carolina.

Robert L. Byrd, Duke University Library

Lindley S. Butler and Alan D. Watson, eds. The North Carolina Experience. An Interpretive And Documentary History. Chapel Hill: University of North Carolina Press, 1984. 467 pp. $\$ 29.95$ cloth; $\$ 9.95$ paper.

The nineteen essays comprising The North Carolina Experience were all written by historical scholars who have published works to their credit. The essays provide a topical survey, beginning with the first settlers, the Indians, and running to the present, of most of the major events, contributions, and issues that should be described and interpreted in any history of North Carolina. There are gaps in this history, though, and the editors warn their readers of this in their preface. To cite a few examples of the gaps, the military role of North Carolinians in our national wars and their contributions in the fields of education, literature, and the arts are not covered.

The second through the sixth chapters survey the period from the beginning of Elizabethan explorations to the entry of the colony of North Carolina into the Revolutionary War. The next chapter describes the otherwise-mindedness of North Carolinians about joining the federal union. This same independent spirit is also captured in "Unwilling Hercules: North Carolina in the Confederacy." The lot of blacks and issues concerning them are treated in chapters on slavery, Reconstruction, and "Sit-ins and Civil Rights." The thread of politics naturally runs through all of the chapters, and two of them specifically concern political parties. The first of these deals with the reemergence of the two-party system after the demise of the Whig Party, and the second one discusses Populism and the Fusionist interlude. Economic issues are dominant in the chapters on the awakening of the "Rip Van Winkle State" in the 
$1850 \mathrm{~s}$, the state's place in the New South, and the effects of the Great Depression and the New Deal on North Carolina. Religion and its influence are discussed in "An Agrarian and Evangelical Culture," and "Professors, Fundamentalists, and the Legislature" examines the evolution controversy of the 1920 s. Interestingly, the chapter outlining the status of women in North Carolina throughout its history comes last. It is only fair to say, however, that the chapters run roughly chronologically, and the struggle of both women and blacks to gain their civil rights and increased opportunities in education and careers is carried into the early 1980 s.

This history was designed to be a "supplementary reader" for college courses in the history of the state and to serve as a "basic text in brief survey courses or as a source book for teachers on the elementary, secondary, or postsecondary level." It meets these goals admirably in the areas that it covers, and these include a very high percentage of the major aspects of the state's history.

Each essay is supported by original documents dealing pro and con with the major theme of the essay and a bibliography. Citations of documents and occasionally of bibliographical items within the essays are adequate substitutes for footnoting these general accounts. The inclusion of documents with each essay serves in part to give the reader insights into and feelings for periods of history as only original records can do. These carefully selected documents, along with occasional mention of differences of opinion by historians on a particular point, should give young students and lay readers some idea of how history is written and lead them to question the alleged definitiveness of any secondary account.

The essays naturally vary somewhat stylistically, but they are all solid and well written. A thirteen-page index to both texts and documents and a list identifying the contributors round out the volume. It is the kind of history of North Carolina that should be available to all students and teachers of the subject and to the general reader.

Mattie U. Russell, Duke University

Michael H. McGee. Separation And Divorce In North Carolina: How To Do It With Or Without A Lawyer. Charlotte: East Woods Press, 1984. 144 pp. $\$ 9.95$ paper.

In 1970, courts in North Carolina granted 13,702 divorces. Ten years later, 28,050 divorces were granted. It is fairly certain that many parties involved in those 28,050 divorces experienced much pain, anger, and frustration. It is also fairly certain that many of the persons involved in those 28,050 divorces did not understand the legal concepts, the legal proceedings, and the ramifications of those proceedings. In Separation and Divorce in North Carolina, Michael H. McGee offers sound legal and practical advice to persons who need information about the separation and divorce laws in North Carolina. McGee writes that his goal with this book is to help persons separating and divorcing begin to make a plan for the future, understand what type of proceedings they are experiencing, and handle some of the unpleasant (yet very necessary) tasks that are required of people who split up. McGee satisfies his objective in this well-written book by dividing the book into three parts and by including sample forms and worksheets to assist the readers.

Part one of the book concerns the law of divorce in North Carolina. This part details the grounds for divorce in North Carolina since the 1983 revision of the divorce laws. Currently there are only two grounds for divorce in North Carolina: (a) one year's separation, or (b) three years' separation if one of the parties is incurably insane. This discussion should clear up any misunderstandings regarding possible grounds for divorce (i.e., adultery). In addition, McGee provides practical advice concerning the necessity of "living apart" during the one year's separation. Courts will interpret the slightest interaction between the two persons during the one year period as not living apart. For example, the North Carolina Court of Appeals recently ruled that one single act of sexual intercourse by the couple, regardless of living arrangements, would end the year's separation. Other chapters in part one concern the legal effects of an absolute divorce, where the case should be brought (jurisdiction and venue), annulment, and a special chapter on the Catholic Church's annulment process.

Part two of Separation and Divorce in North Carolina is devoted to separation periods and the problems that might be encountered by the parties during that period. In this part of the book, McGee explains how to select and work with an attorney. In fact, McGee warns throughout the book that some professional legal advice and assistance are needed. His book does not replace the need for an attorney, except in the case where the parties do not dispute anything. Rather, this book helps the parties to prepare for a meeting with an attorney and to recognize the importance of proceedings that they are approaching. Part two also deals with a new equitable distribution 
law in North Carolina. This law, passed by the North Carolina General Assembly in 1981, essentially guarantees that marital property will be distributed evenly and equally between the two parties. The equitable distribution act has specific requirements that must be followed if the parties wish to take advantage of its provision. In addition, the act is constantly being reviewed by the courts in North Carolina. Another important chapter in part two concerns child custody and support. This extremely important part of the separation and divorce process is clearly described by McGee. McGee correctly notes that the courts in North Carolina award custody of a child to "such person, agency, organization or institution as will, in the opinion of the judge, best promote the interest and welfare of the child." The child custody chapter also includes a very practical checklist to assist in determining the amount of child support payments needed.

Part three of the book includes chapters on how to do your own divorce, the effects of previous divorce actions, how to write a complaint (with a sample), how to file the necessary papers, how to serve the spouse, and how to prepare for court. There is also a short chapter on what to do if the judge denies the divorce. Rarely is an uncontested divorce actually denied; either party, however, can appeal to the North Carolina Court of Appeals if he or she believes that the judge was incorrect in the decision.

The author, a resident of Charlotte and an attorney with the Equal Employment Opportunity Commission in the Charlotte district office, writes clearly and objectively. No reader should experience any problems with this book; legal terms are defined clearly and McGee assumes that the reader has had no previous contact with the law and the courts in North Carolina. McGee recognized the need for a book like this one before he joined the EEOC; prior to working with the $\mathrm{EEOC}$, he was in private practice and worked on a "substantial number of separations and divorces." It is through those experiences that he recognized the need for this type of book.
Some problems do exist with the book. An annoying problem which will be most evident to attorneys, law students, law professors, and law librarians is the use of incorrect legal citation format. Understandably, McGee has attempted to make his references clear for the lay users; however, citations using correct legal abbreviations and format would have been just as easy to use. Probably the most obvious mistake in this area is the lack of dates with some cases cited in the footnotes. The other concern is updating. It is extremely important that anyone who uses the book have access to the latest changes in the divorce laws and the courts' interpretations of those laws. For example, the North Carolina Court of Appeals decided an important equitable distribution case in late 1984. This case further defined what is separate and marital property in North Carolina and should be mentioned in any discussion of the equitable distribution law. Other changes and elaborations are sure to come and must be included in some manner.

The strongest point of the book is McGee's offer of sound practical advice to parties who are involved in a separation and/or divorce proceedings. His best advice is reflected in the following excerpt:
Always try to solve your problems at the lowest level of conflict possible. The scars of an angry court fight can last for years and affect your children and others. Use those weapons only when you personally believe they are necessary to avoid being taken advantage of by your spouse.

Overall, this book is well written and certainly fills a need. McGee should be commended for recognizing the need and writing such a valuable handbook. It should be read by anyone who is contemplating, experiencing, or has experienced divorce. For that reason, every library in North Carolina, whether public or academic, should purchase the book and make the public aware of its existence.

Timothy L. Coggins, University of North Carolina at Chapel Hill 


\section{NCLA Minutes}

\section{North Carolina Library Association Minutes of the Executive Board October 12, 1984}

The Executive Board of the North Carolina Library Association met on October 12, 1984, at the Richard H. Thornton Library, Oxford, North Carolina. Board members present were Leland Park, Pauline Myrick, Jane Williams, Roberta Williams, Eunice Drum, Mertys Bell, Judie Davie, Jerry Thrasher, Robert Burgin, Patsy Hansel, Judith Sutton, Vivian Beech, Mary Avery, and Benjamin Speller. Also present were Rebecca Taylor (representing Children's Services Section), William Mott (representing College and University Section), Stuart Basefsky (representing Documents Section), Euthenia Newman (representing the Round Table for Ethnic Minority Concerns), Johnny Shaver, Arial Stephens, Louise Boone, Mae Tucker, Bob Pollard, and Frank Sinclair.

The meeting was called to order by President Park. He recognized Arial Stephens, director of the Richard H. Thornton Library, who welcomed the group to Oxford and to the library.

President Park gave a report on the meeting of the State Library Commission held in Raleigh on September 11. Results of the evaluation survey on the State Library and the State Librarian were reviewed. The commission also heard an excellent report from the Networking Steering Committee. Board members Judith Sutton and Mary Avery, who attended the meeting of the commission along with President Park, also gave brief reports.

President Park presented the report of the Nominating Committee chaired by H. William O'Shea. Mr. OShea had expressed to President Park the need for clearer guidelines to be included in the charge to the Nominating Committee. After some discussion, the board decided to take no formal action at this time. It was noted, however, that the Nominating Committee's report will also include a nominee for a representative from NCLA to ALA. Ballots for voting on candidates for NCLA officers for the $1985 / 1987$ biennium will be mailed to the membership in April or May 1985.

President Park reported to the board that requests for the NCLA membership mailing list had been received from the Virginia Library Association and the campaign headquarters of Rufus Edmisten, Jim Martin, and D. M. Faircloth.

Several communications from the American Library Association were shared with the board by President Park. Amanda Bible has been appointed to represent NCLA on a committee to plan national library activities to celebrate the 200th anniversary of the adoption of the U. S. Constitution. Dean Edward Holley of UNC-Chapel Hill School of Library Science and Desretta McAllister-Harper of North Carolina Central University School of Library Science have been appointed to the Library Education Centennial Task Force by the ALA Standing Committee on Library Education. The president read a letter from ALA Headquarters explaining why ALA Annual Conferences are sometimes scheduled so that two conferences fall within the same budget year. Space requirements for exhibitors and availability of suitable hotel and meeting facilities were the chief reasons given.
The minutes of the July 20,1984, meeting of the Executive Board were presented by Roberta Williams, secretary. There being no corrections or additions, the minutes were approved as presented.

Eunice Drum gave the treasurer's report and distributed copies to all board members. She noted that the checking account is now drawing interest and that several small accounts have been consolidated to permit more efficiency in banking transactions. On behalf of the Round Table on the Status of Women in Librarianship, Patsy Hansel presented Treasurer Drum with a lovely floral arrangement in appreciation of her hard work in bringing the round table's financial structure and records up-to-date.

Pauline Myrick, vice-president/president-elect, gave an update report on plans for the 1985 Biennial Conference. She recognized Johnny Shaver, who is chairman of local arrangements for the conference. Shaver stated that his experience in working with the recent NCASL conference which was held at the Raleigh Radisson and Civic Center has been very helpful in making plans for the NCLA 1985 conference. He stressed the importance of preplanning as a key to a trouble-free, successful conference.

Arial Stephens discussed the meeting space and parking facilities available at the Raleigh Civic Center and noted that these seem to be quite adequate for all conference functions. He stated that it was the recommendation of the Conference Planning Committee that charges for exhibit booths be set at $\$ 225$, with a pre-registration charge of $\$ 200$ and a 20 per cent discount for multiple booths. These would be the same rates charged for exhibit booths at the 1983 Biennial Conference in Winston-Salem. Robert Burgin moved that the Executive Board approve the recommendation of the Conference Planning Committee regarding charges for booths at the 1985 conference. This motion was seconded and passed.

The Conference Planning Committee requested a recommendation from the Executive Board regarding provisions for exhibit space for non-paying groups. Robert Burgin moved that exhibit space at the 1985 conference be provided to the following only: paying exhibitors; ALA; SELA; and NCLA sections, committees and interest groups. This motion was seconded and passed.

Arial Stephens stated that the Conference Planning Committee recommended that registration fees for the 1985 conference be set as follows:

$\begin{array}{clr}\begin{array}{c}\text { Pre-Registration } \\ \text { NCLA members }\end{array} & \text { Entire Conference } & \$ 20.00 \\ & \text { Per Day } & 15.00 \\ \text { Non-members } & \text { Entire Conference } & 35.00 \\ & \text { Per Day } & 20.00 \\ & & \\ \text { Registration at Conference } & & \$ 25.00 \\ \text { NCLA members } & \text { Entire Conference } & 20.00 \\ & \text { Per Day } & 45.00 \\ \text { Non-members } & \text { Entire Conference } & 40.00\end{array}$

1985 Spring -61 
Library School Students

(any length of time without membership)

It was noted that these rates were the same as those charged for the 1983 conference. Robert Burgin moved that the Executive Board approve the Conference Planning Committee's recommendation regarding registration fees for the 1985 conference. This motion was seconded and passed.

Pauline Myrick stated that Joseph Ruzicka-South will again provide for printing of the conference program. She requested that all information for the program be sent to her as soon as possible. The printing deadline is July $1,1985$.

Euthenia Newman, reporting for the Round Table for Ethnic Minority Concerns, stated that members of the round table are still hoping to sponsor Representative Major Owen as a speaker for the 1985 conference. There is a possibility that the Documents Section of NCLA will co-sponsor this event.

Reporting for North Carolina Libraries, editor Robert Burgin stated that the Fall 1984 issue on children's programming had recently been mailed. Future issues include Winter 1984 (no theme), Spring 1985 (collection development), and Summer 1985 (library history). Deadline for the Winter issue is November 10. Burgin asked the board's advice as to what should be done with the archival copies of North Carolina Libraries that he has in his files. President Park suggested that Burgin contact the Archives Committee to get their advice about this and that he present a recommendation at the next meeting of the Executive Board. The President also requested that Burgin draw up recommended guidelines and a format for written reports by section and committee chairmen and present these for consideration at the January 1985 meeting of the board.

Louise Boone, chair, Governmental Relations Committee, reported that six persons will represent North Carolina at the ALA Legislative Workshop in Washington on January 5, 1985. The Governmental Relations Committee is presently working with various individuals and sections of NCLA on the following issues: (1) clarification of depository laws for North Carolina state documents; (2) the state laws regarding confidentiality of library use records; (3) recommendations from the Executive Committee of NCASL regarding the allocation of media personnel in North Carolina. The Governmental Relations Committee is also considering the possibility of a workshop on lobbying to be held in the spring of 1985 .

Mae Tucker, chair, Constitution, Codes, and Handbook Revision Committee, reported that her committee has approved the request of the Junior Colleges Section to change its name to a title that would more accurately reflect the kinds of libraries represented by the section. Mary Avery, chair, Junior Colleges Section, stated that the section members had already voted to adopt the new name of Community and Junior College Libraries Section. She moved that the Executive Board approve this name change and that the section be officially called the Community and Junior College Libraries Section. This motion was seconded and passed.

Patsy Hansel asked what action had been taken on the question of whether chairpersons of round tables should have voting privileges at NCLA Executive Board meetings. President Park stated that the question has been referred to the Futures Committee for study with a report to be made later to the Executive Board.

Bob Pollard, chairman of the Finance Committee, presented the proposed budget for January 1, 1985 - December 31, 1986. Robert Burgin moved that the proposed budget be accepted as presented. After discussion, the motion was seconded and passed.

The Children's Services Section report was given by Rebecca Taylor for Karen Perry, chair. The section plans to have a breakfast meeting at the October 1985 conference with children's author David McPhail as speaker. The ALSC Notable Showcase will also be presented as a program at the 1985 conference. Special notepads are being sold by members of the section as a fundraising project.

Bill Mott, reporting for the College and University Section, stated that a workshop is being planned for Spring 1985 on academic library networking and online cataloging.

The report of the Documents Section was given by Stuart Basefsky for Emily Correll, chair. The Section will have a workshop at the Durham Public Library on October 19 with Michael Crowell and Raymond Greene as speakers. The section also has a membership drive underway. Stuart Basefsky will replace Emily Correll as section chair at the end of 1984.

Vivian Beech, chair, gave the report for JMRT. The Executive Board of JMRT met on Friday, August 10, in Wilmington. A nominating committee was appointed to secure candidates for vice-chairman/chairman-elect, a vacancy that occurred with the recent resignation of Gayle Keresey. Plans for JMRT's participation in the 1985 NCLA conference are underway. The round table is also considering sponsoring a "Young Librarian's Award."

Reporting for NCASL, Judie Davie stated that the 1984 NCASL Biennial Work Conference held in Raleigh October 3-5 was most successful, with over 900 individuals (including more than 80 exhibitors) participating in the three-day event. A preconference for system level supervisors attracted 69 participants. The Executive Committee of NCASL has forwarded to the NCLA Governmental Relations Committee a legislative platform which includes the following recommendations: (1) the assignment of one media position per 400 students; (2) the allocation of one media supervisor position per county and additional media support personnel at the building level. Elsie Brumback, Emily Boyce, Gayle Keresey, and Helen Tugwell will represent NCASL at the ALA Legislative Workshop in Washington on Saturday, January 5. Judie Davie and Helen Tugwell will represent NCASL at the 1985 ALA Legislative Day. Plans for School Media Day, 1985, and for NCASL's participation in the 1985 Biennial Conference are underway.

Dr. Benjamin F. Speller, Jr., chair, reported that the Resources and Technical Services Sections had held a successful mini-conference on "The Changing Role of the Technical Services Librarian" in Whispering Pines on September 26 and 27. Total registration for this conference was 128 , including representatives from college and university libraries, community college libraries, public libraries, special libraries, and school libraries.

Judith Sutton, chair, Public Libraries Section, reported on the meeting of the Planning Council held October 4, 1984, at the Durham County Public Library. The Public Library Section will send Nancy Massey as its representative to the Greenbrier in White Sulphur Springs, West Virginia, November 3-6, 1984, for the Eastern Regional Workshop planning for the ALA/NEH-sponsored "Let's Talk About It" Workshop. The Development Committee has arrived at the draft stage of an eagerly awaited publication, "North Carolina Public Libraries Disruptive Behavior Policy."

Patsy Hansel reported that the RTSWL summer workshop, "The Good, The Bad, The Ugly: Documenting Employee Performance," was very successful, with 60 participants attending. The evaluations of the workshop were very positive, and there was interest expressed in more workshops related to personnel and general management concerns in libraries.

Other reports were given by Arial Stephens (Network Steering Committee), Mary Avery (Community and Junior College Libraries Section), Leland Park for Rebecca Ballentine (SELA), and Arial Stephens for Dorothy R. Burnley (Trustees).

Ben Speller gave a brief report on the Round Table for Ethnic Minority Concerns workshop, "Promoting Oneself in the Field of Librarianship," held October 5 at Shaw University in Raleigh. 
Johnny Shaver advised that listing of NCLA-sponsored workshops in various North Carolina Department of Public Instruction newsletters could be obtained by forwarding information to Director, Division of Public Information and Publications, North Carolina Department of Public Instruction, Raleigh, North Carolina 27611.

President Park reminded everyone of the next meeting of the Executive Board, to be held January 25 in Winston-Salem.

There being no further business, the meeting adjourned.

Roberta S, Williams, Secretary

\section{Former Times Editor Speaks to Friends}

Clifton Daniel, international correspondent and a retired editor of the New York Times, promoted libraries, along with two highly successful first-novelists, Josephine Humphreys and Louise Shivers, at the fourteenth annual Friends of the Library Book and Author Luncheon on the campus of Queens College in Charlotte. The writers told the 427 luncheon guests that their literary tasks were as amazing as delivering a first-born calf in Texas, more invigorating than seven years of raising children and changing diapers, and as challenging as conversing with British royalty about Virginia ham.

Humphreys (Dreams of Sleep, Viking Press, 1984) set her fictitious characters in the back streets of Charleston, South Carolina.

Duplicating her daughters' college creative writing assignments, Shivers (Here To Get My Baby Out of Jail, Random House, 1983) rediscovered her own literary talent which she had suppressed since her freshman college days in the late $1940 \mathrm{~s}$.

Ann Schrader, President of the Friends, said over 200 members had to be denied tickets because of lack of room. Co-chairs Harriet Moore and Margaret Harbison reported over 100 copies of the authors' works were purchased and autographed.

Stewart Lillard, Library Director, Queens College

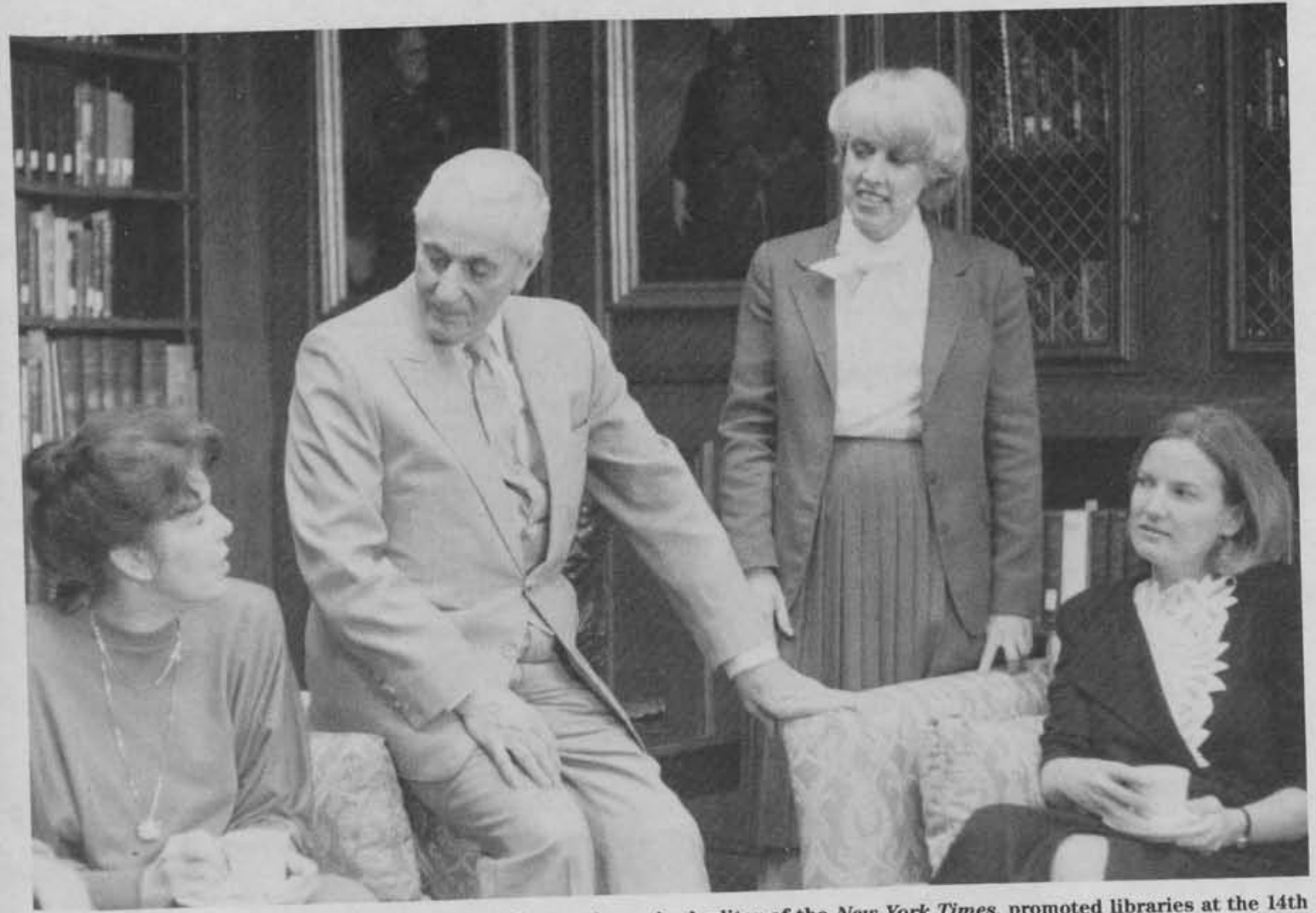

Clifton Daniel (center), international correspondent and a retired editor of the New York Times, promoted libraries at the 14th annual Friends of the Library Book and Author Luncheon at Queens College in Charlotte. Joining Daniel were first novelsts Josephine Humphreys (far right) and Lo fictitious Tarborough of Shivers's novel. 


\section{Join NCLA}

\section{What is NCLA?}

- the only statewide organization interested in the total library picture in North Carolina, whose purpose is to promote libraries and library service in the state

- an affiliate of the American Library Association and the Southeastern Library Association, with voting representation on each council

\section{What are the benefits of membership?}

- provides opportunities for interaction among those interested in good library service

- entitles you to receive North Carolina Libraries, a quarterly journal, winner of the prestigious H. W. Wilson Award in 1981

- gives you the opportunity to develop leadership skills

- enables you to attend workshops, continuing education programs, and conferences at reduced rates

- keeps you informed on library developments in the state through an information network and publications
- gives you individual voting rights in the association

- encourages support staff and paraprofessionals to join at reduced rates

- entitles you to membership in one of the sections or roundtables of the association

To enroll as a member of the association or to renew your membership, check the appropriate type of membership and the sections or roundtables which you wish to join. NCLA membership entitles you to membership in one of the sections or roundtables shown below at no extra cost. For each additional section, add $\$ 4.00$ to your regular dues.

Return the form below along with your check or money order made payable to North Carolina Library Association. All memberships are for two calendar years. If you enroll during the last quar ter of a year, membership will cover the next two years.

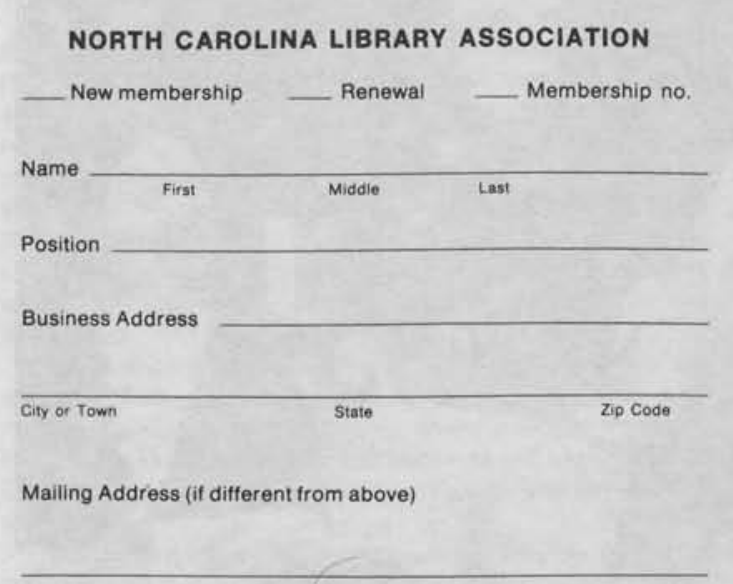

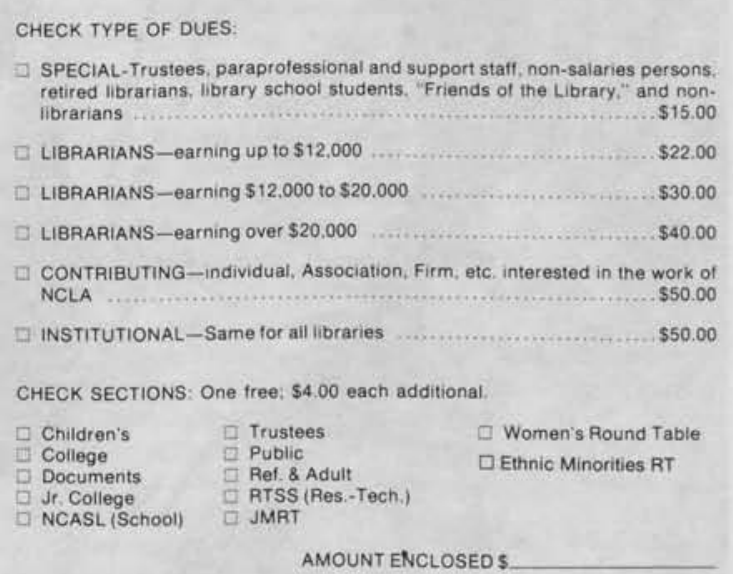

7 SPECIAL-Trustees, paraprofessional and support staff, non-salaries persons.

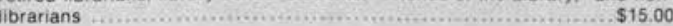

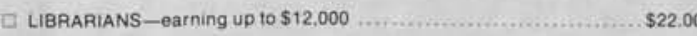

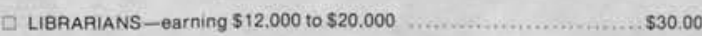

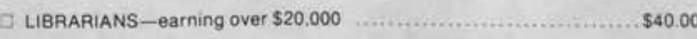

CONTRIBUTING - Individual, Association, Firm, etc. interested in the work of

INSTITUTIONAL-Same for ail libraries ............................. $\$ 50.00$

CHECK SECTIONS: One free: $\$ 4.00$ each additional

\begin{tabular}{|c|c|c|}
\hline $\begin{array}{l}\text { Children's } \\
\text { College } \\
\text { Documents } \\
\text { Jr. College } \\
\text { NCASL. (School) }\end{array}$ & $\begin{array}{l}\square \text { Trustees } \\
\square \text { Public } \\
\square \text { Ref. \& Adult } \\
\text { RTSS (Res.-Tech.) } \\
\text { JMRT }\end{array}$ & $\begin{array}{l}\square \text { Women's Round Table } \\
\square \text { Ethnic Minorities RT }\end{array}$ \\
\hline
\end{tabular}

Mail to: Eunice Drum, Treasurer, NCLA, Division of State Library, 109 East Jones Street, Raleigh, NC $2 \dot{7} 611$. 


\section{EDITORIAL STAFF}

\section{Editor}

ROBERT BURGIN

School of Library Science

North Carolina Central

University

Durhasn, NC 27707

(919) 683-6485

\section{Associate Editor \\ PATSY J HANSEL \\ Cumberland County Public Library \\ Box 1720 \\ Faverteville, NC28302 \\ (9i9) $483-8600$}

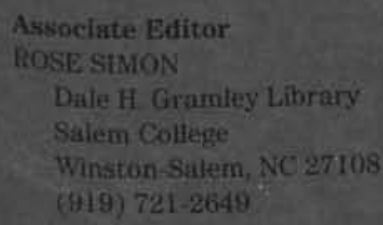

\section{Book Review Editor}

ALICE COTTEN

Wilson Library

UNC-Chapel Hill

Chapel Hill, NC 27514

(919) $962-1172$

\author{
Children's Services \\ BONNIE FOWLER \\ 237 Arrowleaf Drive \\ Lewrisville, NC 27023 \\ (919) $945-5236$ \\ College and University \\ MARIE DEVINE \\ Ramsey Library \\ UNC-Asheville \\ Asheville, NC 28814 \\ (704) $258-6625$
}

Community and Junior

College Libraries

BEVERLEY GASS

Guilford Tectricat Community. Gollege

Box 309

Jamestown, NC 27282

(919) 292-1101

Documents
MICHAEL COTTER

I.Y. Joyner Library

East Carolina University

Greenville, NC 27834

(918) 757.6533
Junior Members Roundtable IOHN BURNS
Eibert ivey Memorial Library
420 Third Avenue NW
Hiekory. NC 28601
(704) 322-2905

\author{
N.C. Association of School \\ Librarians \\ FRANCES BRADBURN \\ Greensboro Day School \\ Box 9361 \\ Greensboro, NC 27429-0861 \\ (919) 288-8590
}

\author{
Public Library \\ BOB RUSSELL. \\ Eibert Ivey Memorial Library \\ 420 Third Avenue NW \\ Hickory, NC 28601 \\ (704) $322-2905$
}

\section{Reference and Adult Services \\ ILENE NEISON \\ Duke University Library \\ Durham, NC 27606 \\ (919) $684: 2373$}

\section{Resources and Technical Services GENE LEONARDI \\ Shepard Library \\ North Carolina Central University \\ Durham, NC27707 \\ (919) $683-6220$}

\section{Round Table for Ethnic Minorty \\ Concerns}

SYLVLA SPRINKLE-HAMLIN

Forsyth County Public Library

660 West Fth Street

Winston-Salem, NC 27701

(919) $727-2176$

Round Table on the Status of

Women in Librarianship

MARY MCAFEE

Forsyth Gounty Public Library

660 West 5th Street.

Winston-Satem, NO 27101

(819) $727-2264$

Trustees

Address all correspondence to: Robert Burgin, Editor

Sehool of Library Science, N.C.C.U., Durham, NC 277no.

North Garolina Libraries, published four times a year, is the official publication of the North Carolina Library Association. Membership dues include a subscription to North Carolina Libraries. Membership information may be obtained from the treasurer of NCLA.

Subscription rates for 1984 are $\$ 20.00$ per year, or $\$ 5.00$ per issue, for domestie subscriptions; $\$ 25.00$ per year, or $\$ 7.00$ per issue, for foreign subscriptions. Backfiles are maintained by the editor, Microfilm copies are available through University Microfilms International. North Carolina Libraries is indexed by Library Literature and publishes its own annual index.

Editorial correspondence should be addressed to the editor, advertisement correspondence should be addressed to the advertising mamager. Articles are juried.

North Canolina bibraries is printed by Meridional Publications, Wake Forest, NC.

Issue deadlines are February 10, May 10, Angust 10, and November 10. 


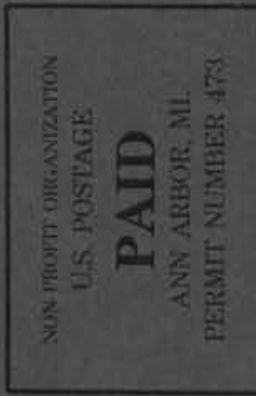

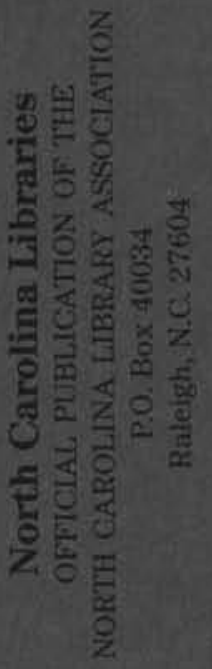

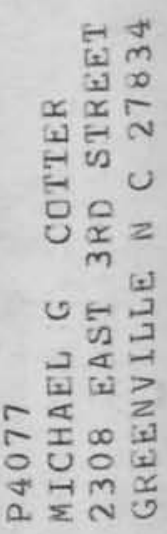

